HNF-SP-1240

Revision 1

\title{
Fiscal Year 1999 Multi-Year Work Plan Advanced Reactors Transition Program
}

Date Published

September 1998

Prepared for the U.S. Department of Energy Assistant Secretary for Environmental Management

mwor davan. Hawrord, me. Richland, Washington 
LECAL OSCLAMER

This report was propared as an account of work sponsored by en agency of the United States Government. Neither the United States Government nor any sgency thereof, nor eny of their employeos, nor any of their contractors, subcontractors or their employoes, makes any warranty. exprese or impliad, or aseumes any logal liability or reeponeibility for the eccurecy, completeness, or any third party's use or the results of such use of any information, apparatus, product, or prooses dieclosed, or ropresents that its use would not infringe privetely owned rights. Reference herein to any specific commercial product, process, or service by trede name, trademark, manufacturer, or otherwise, does not nocessarily constitute or imply its endorsement, recommendation, of favoring by the United States Government or any agency thereof or its contractors or subcontractors. The views and opinions of authors expressed horein do not necessarily state or reflect those of the United States Government or any agency thareof.

This report has beon reproduced from the best available copy.

Available in paper copy and microfiche.

Aveilable to the U.S. Department of Energy

and its contractors from

U.S. Department of Energy

Office of Scientific and Technical Information (OST)

P.O. Box 62

Oek Ridge, TN 37831

(615) 576-8401

Aveilable to the public from the U.S. Department of Commerce

Nationel Technicel Information Service (NTIS)

5285 Port Royal Road

Springfield, VA 22161

(703) $487-4650$

Printed in the United Steten of Amrice

DISCLM-1.CHP (8-85) 


\section{RELEASE AUTHORIZATION}

Document Number: HNF-SP-1240, Rev. 1

Document Title:

Fiscal Year 1999 Multi-Year Work Plan, Advanced Reactors Transition Program

This document, reviewed in accordance with DOE Order 1430.1D, "Scientific and Technical Information Management," and DOE G 1430.1D-1, "Guide to the Management of Scientific and Technical Information," does not contain classified or sensitive unclassified information and is:

APPROVED FOR PUBLIC RELEASE

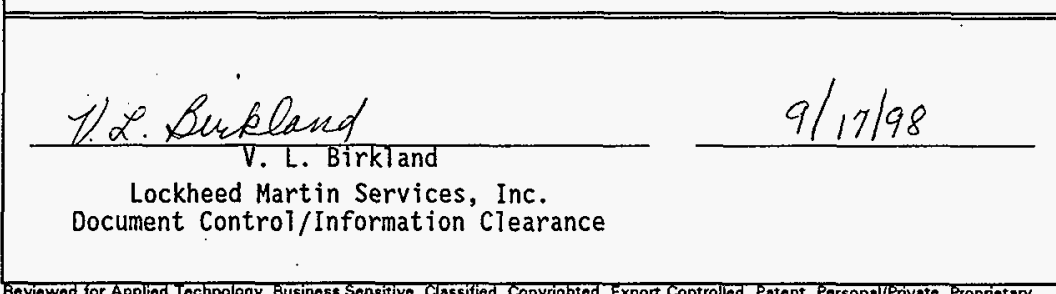

Reviewod for Appliod Tochnology, Business sensitive, Classified, Copyrighted, Export Controlled, Patent, PorsonallPrivate, Proprietary, Protected CRADA. Trademark, Unclassified Controlled Nuclear information.

LEGAL DISCLAIMER. This report was prepared as an account of work sponsored by an agency of the United Statos Government. Neither the United States Govemment nor any spency thereof, not any of their employees, nor any of their contractors, subcontractors or their omployees, mokes any warranty. exprese or impliad, or ascumes any logal liability or responsibility for the accuracy. comploteness, or any third.party's use or the rosulte of such use of any information, apparatus, product, or procese disclosed, or represente that its use would not infringe privatoly owned righte. Reference herein to any spocific commerciol product, process, or service by trade name, trademark, manufacturer, or otherwise, does not neceszarily constitute or imply its endorsement, recommendation, or favoring by the United States Government or any agency thereof or its contractors or subcontractors. The views and opinions of authors expressed herein do not necesssrily state or reflect those of the United States Government or any agancy thereof. This report has been reproduced from the bect available copy. Printed in the United States of America. 
HNF-SP-1240

Rev. 1

Document Title:

Fiscal Year 1999 Multi-Year Work Plan

Advanced Reactors Transition Program

Prepared by:

Oa raso

D. A. Gantt, Manager

Project Integration

Reviewed by:

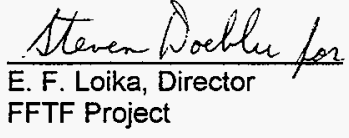

Concurred by:

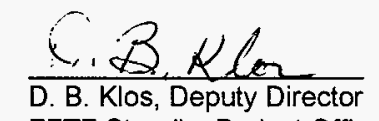

FFTF Standby Project Office, FDH

Concurred by:

Approved by:
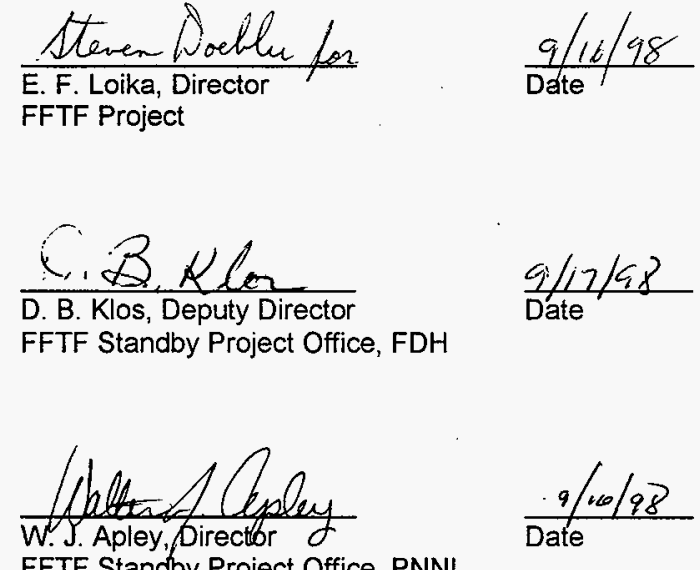

FFTF Standby Project Office, PNNL

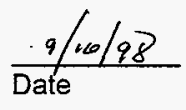

O. A. Farabee, Director

FFTF Standby Project Office, DOE-RL 
HNF-SP-1240

Rev. 1

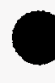


Table of Contents

A.1.0 Technical Baseline A.1-1

A.1.1 Mission Statement A.1-1

A.1.2 Boundary Diagram with Major Facilities $\quad$ A.1-1

A.1.3 Facility Responsibility Assignment Matrix $\quad$ A.1-1

A.1.4 Project Planning Assumptions $\quad$ A.1-2

A.1.5 Risk Management $\quad$ A.1-2

A.1.6 Technical Issues Management List $\quad$ A.1-2

A.2.0 Project Hanford Breakdown Structure (PHBS)

A.2-1

A.2.1

A.3

A. 4

PHBS Hierarchy

Schedule Baseline

A.2-1

Cost Baseline

A.3-1

A.4.1 Estimate Basis

$\begin{array}{ll}\text { A.4.2 } & \text { Summary of Life Cycle Cost Baseline (BCWS) by Project } \\ \text { A.4.3 } & \text { Summary of Budget Authority by Project }\end{array}$

A.4-1

A.4-1

A.4.3

$\begin{array}{ll}\text { B.1. } & \text { Advanced Reactors Transition (RL-TP11) } \\ \text { B.1.1.0 Advanced Reactors Transition Technical Bas }\end{array}$

A.4-2

A.4-6

B.1.1-1

B.1.1.0

Advanced Reactors Transition Mission

B.1.12

Advanced Reactors Transition End Point Targets from Hanford Strategic Plan

B.1.1-1

B.1.1.2

Advanced Reactors Transition Major Facilities

B.1.1.4

Drivers for Advanced Reactors Transition

B.1.2.0

Advanced Reactors Transition Work Breakdown Structure (WBS)

B.1.1-1

B.1.1-1

B.1.1-1

B.1.1-9

B.1.2-1

Advanced Reactors Transition WBS Hierarchy

B.1.2.2

Advanced Reactors Transition WBS Dictionary

B.1.2-1

B.1.2-1

B.1.2.3

Advanced Reactors Transition Responsibility Assignment Matrix (RAM)

B.1.2-6

B.1.3

B.1.3.1

Advanced Reactors Transition Schedule Baseline

B.1.3.2

Advanced Reactors Transition Project Master Baseline Schedule (PMBS)

B.1.3-1

Advanced Reactors Transition Execution Year PMBS

B.1.3-4

Advanced Reactors Transition Milestone List (DOE-HQ, RL, FO)

B.1.3-5

B.1.3.4

Advanced Reactors Transition Milestone Description Sheets

B.1.3-6

B.1.4

Advanced Reactors Transition Cost Baseline

B.1.4.1

Advanced Reactors Transition Life Cycle Cost Baseline (BCWS)

B.1.4-1

B.1.4.2

Advanced Reactors Transition Budget Authority (B/A)

B.1.4-3

B.2

B.2.1.0

FFTF Project (RL-MS01)

B.2.1-1

FFTF Project Technical Baseline

B.2.1-1

B.2.1.1

B.2.1.2

FFTF Project Mission

B.2.1-1

FFTF Project End Point Targets from Hanford Strategic Plan

B.2.1-2

B.2.1.3

FFTF Project Major Facilities

B.2.1-3

Drivers for FFTF Project

B.2.1-9

B.2.2.0

FFTF Project Work Breakdown Structure (WBS)

B.2.2-1

B.2.2.1

FFTF Project WBS Hierarchy

B.2.2-1

FFTF Project WBS Dictionary

B.2.2-2

B.2.2.2

B.2.2.3

B.2.3

FFTF Project Responsibility Assignment Matrix (RAM)

B.2.2-7

B.2.3.1

B.2.3.2

FFTF Project Schedule Baseline

FFTF Project Execution Year PMBS

B.2.3-1

FFTF Project TPA Milestones Being Renegotiated

B.2.3-6

FFTF Project Milestone List (DOE-HQ, RL, FO)

B.2.3-8

B.2.3.4

FFTF Project Milestone Description Sheets)

B.2.3-9

B.2.4

B.2.4.1

FFTF Project Cost Baseline

B.2.4.2

FFTF Project Execution Year Cost Baseline (BCWS)

B.2.4-1

FFTF Project Budget Authority (B/A)

B.2.4-3 
C. Supplemental information

C. $0-1$

C.1

Project Priority List, Advanced Reactors Transition

C.1-1

C. 2

Performance Enhancements, Advanced Reactors Transition

C.2-1

C.3

Performance Measures

C. 3.1

Advanced Reactors Transition (RL-TP11)

C. $3-1$

C. 3.2

C. 4

FFTF Project (RL-MS01)

C.3-3

C. 4.1 MYWP Update Summary

C.4-1

C. 4.2

Advanced Reactors Transition (RL-TP11)

C.4-3 


\section{A.1.0 Technical Baseline}

The MYWP technical baseline describes the work to be accomplished by the Project and the technical standards which govern that work.

\section{A.1.1 Mission Statement}

The Advanced Reactors Transition (ART) has two missions. One, funded by DOE-EM is to transition assigned, surplus facilities to a safe and compliant, low-cost, stable, deactivated condition (requiring minimal surveillance and maintenance) pending eventual reuse or D\&D. Facilities to be transitioned include the 309 Building / Plutonium Recycle Test Reactor (PRTR) and Nuclear Energy (NE) Legacy Facilities.

The second mission, funded by DOE-NE, is to maintain the Fast Flux Test Facility (FFTF) and affiliated 400 Area buildings in a safe and compliant standby condition. The condition of the plant hardware, software and personnel is to be preserved in a manner not to preclude a plant restart.

\section{A.1.2 Boundary Diagram with Major Facilities}

The following table indentifies the major facilities that interface with this Project. The left column of the table identifies the major facilities that generate waste, materials, or infrastructure for this Project. The right column of the table identifies the major facilities that will receive waste and materials from this Project. The center column lists the major facilities managed by this Project.

Table A-1 Advanced Reactors Transition Project Boundary Diagram

\begin{tabular}{|c|c|c|}
\hline Major Input Interfaces & Proiect facilities & Major Output Interfaces \\
\hline $\begin{array}{l}\text { Extemal Interfaces } \\
\text { Hanford Legacy } \\
\text { Hanford Site Envitonmental System Interfaces } \\
3717 \text { B } \\
\text { CP General Purpose Shop } \\
\text { Electrical Distribution System } \\
\text { General Purpose Shops } \\
\text { Misc Rad Labs } \\
\text { S600 Electrical Distribution } \\
\text { S600 General Purpose Office } \\
\text { S600 General Purpose Shop } \\
\text { S600 General Purpose Warehouse } \\
\text { S600 Telecommunications System }\end{array}$ & $\begin{array}{c}\text { FFTF } \\
309 \text { Facility } \\
\text { NE Legacy Facilities }\end{array}$ & $\begin{array}{l}\text { External Interfaces } \\
\text { Hazardous Waste Disposal Contracts } \\
\text { Offsite Landfill } \\
\text { Hanford Site Environmental System Interfaces } \\
200 \text { Interim Storage Area (ISA) } \\
222-S \text { Laboratory } \\
242 \mathrm{~A} \\
300 \text { Area Ireated Effluent Disposal Facility } \\
\text { Central Waste Complex } \\
\text { Double Shell Tank (DST) System } \\
\text { Low-Level Waste Burial Grounds } \\
\text { PFP } \\
\text { Sanitary Landfill }\end{array}$ \\
\hline
\end{tabular}

\section{A.1.3 Facility Responsibility Assignment Matrix}

This section provides a table that identifies the sub-projects, major facilities, and the life cycle assignments. 
Table A-2 Facility Responsibility Assignment Matrix

\begin{tabular}{|c|c|c|c|c|c|c|c|c|c|}
\hline \multirow{3}{*}{ Facility } & \multicolumn{9}{|c|}{ Life Cycle Phase * } \\
\hline & \multirow{2}{*}{$\begin{array}{l}\text { Program } \\
\text { Planning }\end{array}$} & \multirow{2}{*}{$\begin{array}{c}\text { Pre } \\
\text { Conceptual } \\
\end{array}$} & \multirow[b]{2}{*}{ Conceptual } & \multicolumn{3}{|c|}{ Execute } & \multirow[b]{2}{*}{ O\&M } & \multicolumn{2}{|c|}{ Close Out } \\
\hline & & & & Design & Constnetion & Turnover & & Post Ops & D\&D \\
\hline FFTF & RL-MS01 & & & & & & RL-MSO1 & $\begin{array}{l}\text { RL-MS01 } \\
\text { RL-ER05 }\end{array}$ & $\begin{array}{l}\text { RL-ER06 } \\
\text { RL-ER07 }\end{array}$ \\
\hline 309 Facility & RL-TP11 & & & & & & & $\begin{array}{l}\text { RL-TP11 } \\
\text { RL-ER05 }\end{array}$ & RL-EROG \\
\hline NE Leqacy Facilities & RL-TP11 & & & & & & & RL-TP11 & RL-ER05 \\
\hline
\end{tabular}

- RL PBS Identifier Index:

RL-MSO1 - FFTF Project

RL-ER05 - Surveillance and Maintenance

RL-ER06 - Decontamination \& Decommissioning

RL-ER07 - Long Term Surveillance and Maintenance

RL-TP11 - Advanced Reactors Transition

\section{A.1.4 Project Planning Assumptions}

This section contains the issues that affect the project. These include project specific issues, as well as site-level issues that have been assigned to the project for resolution. It also contains the assumptions that are used as a basis for the development of project plans until the issues are formally resolved with records of decision. The "Champion" column determines if the Project has lead responsibility or is an affected participant. If the champion belongs to the Project, the Project has the lead. If not, the Project is an affected participant. Project plans include appropriate activities and resources for resolving these issues.

Table A-3 Project Issues And Assumplions

\begin{tabular}{|c|l|l|c|c|}
\hline \multicolumn{1}{|c|}{ ISSUE } & \multicolumn{1}{|c|}{ PLANNING ASSUMPTION } & CHAMPION \\
\hline 1 & $\begin{array}{l}\text { TPA Milestone will Not Be Met Because the FFTF has } \\
\text { been placed in 'standby' work required in order to achieve } \\
\text { TPA Milestones is not being performed and is not presently } \\
\text { Scheduled. }\end{array}$ & $\begin{array}{l}\text { Submitted TPA change requests will be approved, placing } \\
\text { he affected milestones 'in abeyance' until after a mission } \\
\text { decision is made. }\end{array}$ & $\begin{array}{c}\text { Farabee } \\
\text { Klos }\end{array}$ \\
\hline 2 & $\begin{array}{l}\text { Sodium Disposition Potential use as a neutralization agent } \\
\text { for tank waste is projected to be beyond 2015. }\end{array}$ & $\begin{array}{l}\text { Interim storage in the 400 Area and Central Waste Complex } \\
\text { (CWC) until Tank Waste treatment processes are defined. } \\
\text { RL will include consideration of NaOH product in future } \\
\text { privatization contracls. }\end{array}$ & $\begin{array}{c}\text { Farabee } \\
\text { Klos }\end{array}$ \\
\hline
\end{tabular}

\section{A.1.5 Risk Management}

Mission Risk Management Plans are not available at this time, however, detailed risk analysis can be found in the following documents:

- PBS Level, Risk Data Tables, Section C.1.1

- PBS Level, Risk Evaluation Narrative, Section D.1.6

- Unit of Analysis Level, current PPL and IPL located on Hanford shared area: lap014lpbs

\section{A.1.6 Technical Issues Management List}

This section identifies the site-level issues and planning assumptions from Section A.1.4 that have been assigned to 
the project for resolution. This section is used to delineate the site-level issues and planning assumptions from the project specific issues and planning assumptions.

Table A-4 Site Technical /ssues And Assumptions

\begin{tabular}{|l|l|l|c|}
\hline \multicolumn{2}{|c|}{ ISSUE } & \multicolumn{1}{c|}{ PLANNING ASSUMPTION } & CHAMPION \\
\hline 1 & $\begin{array}{l}\text { Sodiam Disposition Potential use as a neutralization agent } \\
\text { for tank waste is projected to be beyond } 2015 .\end{array}$ & $\begin{array}{l}\text { interim storage in the 400 Ares and Central Waste Complex } \\
\text { (CWC) until Tank Waste treatment processes are defined. } \\
\text { RL will include consideration of NaOH product in future } \\
\text { privatization contracts. }\end{array}$ & $\begin{array}{c}\text { Farabee } \\
\text { Klos }\end{array}$ \\
\hline
\end{tabular}




\section{A.20 Project Hanford Breakdown Structure (PHBS)}

\section{A.21 PHBS Hierarchy}

\begin{tabular}{lll}
\hline RL PBS & RL WBS & Title \\
\hline RL-MS01 & 1.12 & Advanced Reactors Transition Project \\
& 2.01 .01 .01 .21 .01 & FFTF Project \\
& 2.01 .01 .01 .21 .01 .01 & FFTF \\
& 2.01 .01 .01 .21 .01 .01 .01 & Maintain Safe \& Compliant Materials in Fast Flux Test Facility \\
& 2.01 .01 .01 .21 .01 .01 .02 & Remove Materials from FFTF \\
& 2.01 .01 .01 .21 .01 .01 .03 & Maintain Safe \& Compliant Fast Flux Test Facility in South 600 Areas \\
& 2.01 .01 .01 .21 .01 .01 .04 & Transition the Fast Flux Test Facility \\
\hline RL-TP11 & 1.12 .01 & Advanced Reactors Transition \\
& 1.12 .01 .01 & NE Legacy Facilities \\
& 1.12 .01 .01 .01 & Maintain Safe \& Compliant NE Legacy Facilities \\
& 1.12 .01 .01 .02 & Transition NE Legacy Facilities \\
& 1.12 .01 .02 & 309 Facility \\
& 1.12 .01 .02 .01 & Maintain Safe \& Compliant 309 Building \\
& 1.12 .01 .02 .02 & Transition 309 Building \\
\hline
\end{tabular}


Rev. 1

\section{A.3.0 Schedule Baseline}

Schedules are provided at the PBS Level only. (See PBS Level section.) 


\section{A.4.0 Cost Baseline}

\section{A.4.1 Basis of Estimate}

The Advanced Reactors Transition cost estimate has been developed using Activity Based Cost (ABC) estimating techniques. Planning rates and escalation applied to these estimates are consistent with those developed by the Fluor Daniel Hanford Company (FDH) Chief Financial Officer and approved by RL. The supporting information is maintained by the FFTF Transition Project Office in the 400 Area 4710 Building. 
ADVANCED REACTORS TRANSITION

SUMMARY OF LIFE CYCLE COST BASELINE (BCWS) BY YEAR

BY PROJECT BASELINE SUMMARY (PBS)

FY 1999

(\$000s)

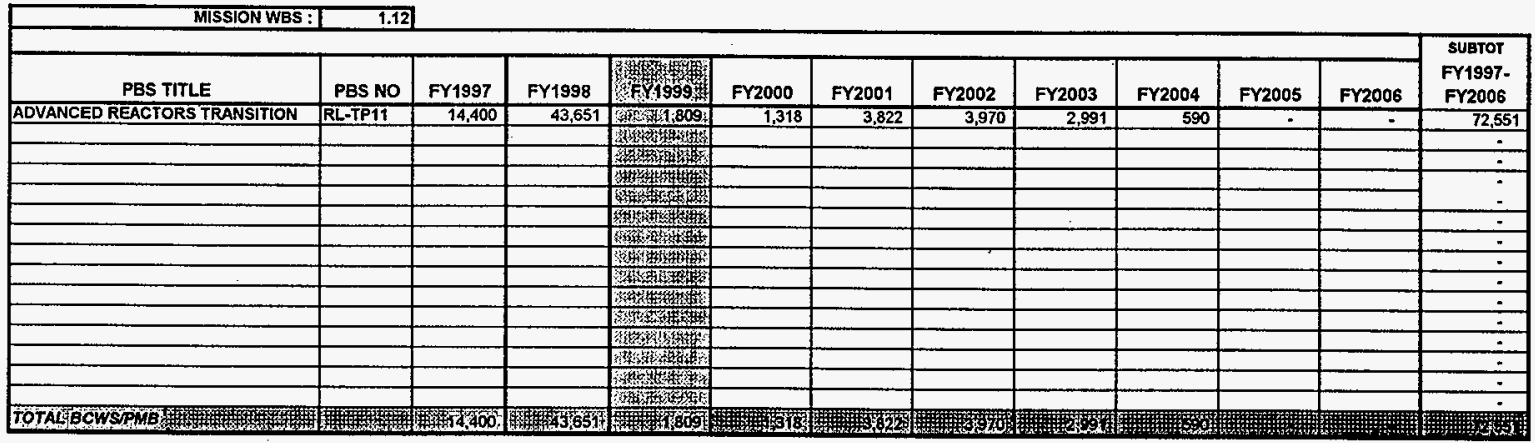

${ }^{1}$ Budgeted Cost of Work Scheduled (BCWS) Equals Performance Measurement Baseline (PMB); Expense Carryover is NOT Included. 
EXHIBIT 1

ADVANCED REACTORS TRANSITION SUMMARY OF LIFE CYCLE COST BASELINE (BCWS) BY YEAR

BY PROJECT BASELINE SUMMARY (PBS)

FY 1999

(\$000s)

\begin{tabular}{|c|c|c|c|c|c|c|c|c|c|c|c|c|c|c|}
\hline MISSION WES: & $\begin{array}{r}1.12 \\
\end{array}$ & & & & & & & & & & & & & \multirow[b]{2}{*}{$\begin{array}{l}\text { TOTAL } \\
\text { FY1997- } \\
\text { FY2050 }\end{array}$} \\
\hline PES TITLE & PBS NO & FY2007 & FY2008 & FY2009 & FY2010 & $\begin{array}{l}\text { FY2011- } \\
\text { FY2015 }\end{array}$ & $\begin{array}{l}\text { FY2016- } \\
\text { FY2020 }\end{array}$ & $\begin{array}{l}\text { FY2021- } \\
\text { FY2025 }\end{array}$ & $\begin{array}{l}\text { FY2026- } \\
\text { FY2030 }\end{array}$ & $\begin{array}{l}\text { FY2031- } \\
\text { FY2035 }\end{array}$ & $\begin{array}{l}\text { FY2036 } \\
\text { FY2040 }\end{array}$ & $\begin{array}{l}\text { FY2041- } \\
\text { FY2045 }\end{array}$ & $\begin{array}{l}\text { FY2046 } \\
\text { FY2050 }\end{array}$ & \\
\hline ADVANCED REACTORS TRANSITION & RL-TP11 & & & & - & & - & & & & & & & 72,551 \\
\hline & & & & & & & & & & & & & & - \\
\hline & & & & & & & & & & & & & & : \\
\hline & & & & & & & & & & & & & & - \\
\hline & & & & & 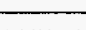 & & & & & & & & & - \\
\hline & & & & & & & & & & & & & & $\because$ \\
\hline & & & & & & & & & & & & & & $\overline{-}$ \\
\hline & & & & & & & & & & & & & & $\div$ \\
\hline & & & & & & & & & & & & & & - \\
\hline & & & & & & & & & & & & & & $\div$ \\
\hline 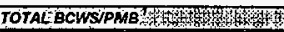 & 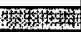 & 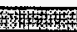 & 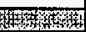 & 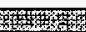 & 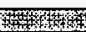 & 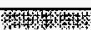 & 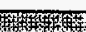 & W & 地 & 敉 & 19) & F) & 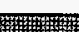 & 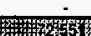 \\
\hline
\end{tabular}

${ }^{1}$ Budgeted ${ }^{1}$ Budgeted Cost of Work Scheduled (BCWS) Equals Performance Measurement Baseline (PMB); Expense Carryover is NOT Included. 
FAST FLUX TEST FACILITY

SUMMARY OF LIFE CYCLE COST BASELINE (BCWS) BY YEAR

BY PROJECT BASELINE SUMMARY (PBS)

FY 1999

(\$000s)

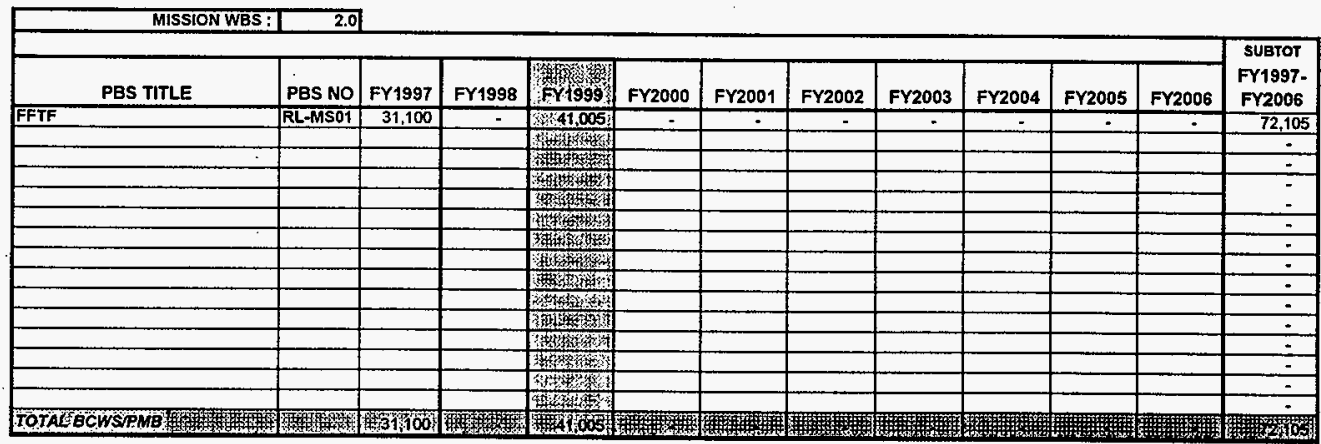

'Budgeted Cost of Work Scheduled (BCWS) Equals Performance Measurement Baseline (PMB); Expense Carryover is NOT Include 
FAST FLUX TEST FACILITY

SUMMARY OF LIFE CYCLE COST BASELINE (BCWS) BY YEAR

BY PROJECT BASELINE SUMMARY (PBS)

FY 1999

(\$000s)

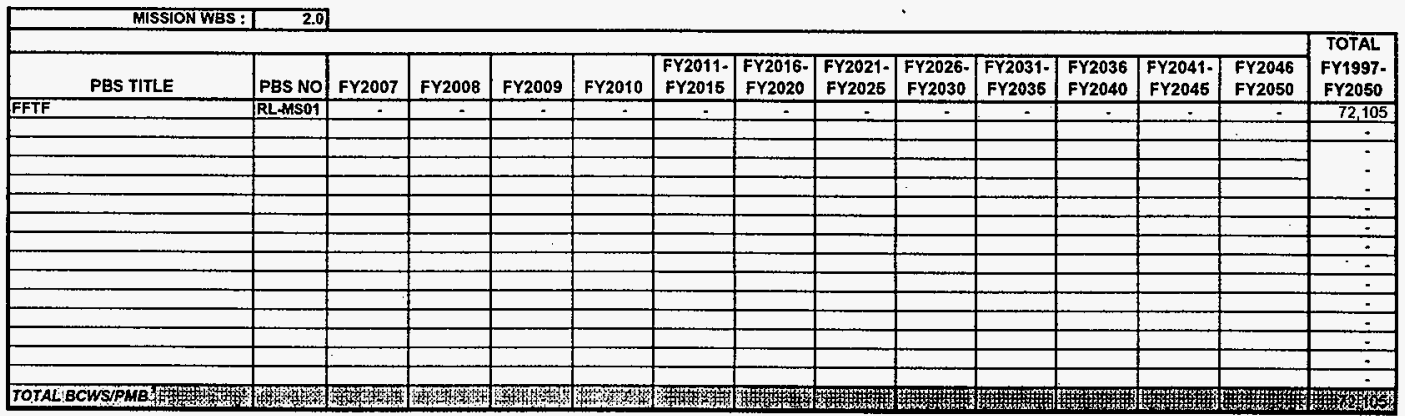

'Budgete 'Budgeted Cost of Work Scheduled (BCWS) Equals Performance Measurement Baseline (PMB); Expense Carryover is NOT Included. 


\section{ADVANCED REACTORS TRANSITION}

\section{SUMMARY OF BUDGET AUTHORITY (B/A) BY YEAR BY PROJECT BASELINE SUMMARY (PBS) \\ FY 1999 \\ (\$000s)}

\begin{tabular}{|c|c|c|c|c|c|}
\hline MISSION WBS: & 1.12 & & & & \\
\hline & & \multirow{2}{*}{$\begin{array}{l}\text { TARGET } \\
\text { B/A } \\
\text { FY1998 }\end{array}$} & \multirow{2}{*}{$\begin{array}{l}\text { CARRYOVER } \\
\text { FROM } \\
\text { FY1998 }\end{array}$} & \multirow{2}{*}{\multicolumn{2}{|c|}{ 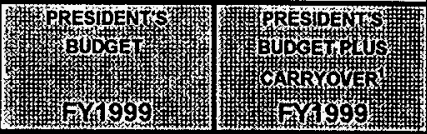 }} \\
\hline PBS TITLE & PBS NO & & & & \\
\hline ADVANCED REACTORS TRANSITION & RL-TP11 & 38,380 & 179 & (3is & (2) 2086 \\
\hline & & & & (4) & (19) \\
\hline & & & & 3 & 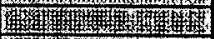 \\
\hline & & & & 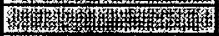 & (I) \\
\hline & & & & 斤 & (3) \\
\hline & & & & $y^{(1)}$ & 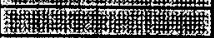 \\
\hline & & & & (3) & U \\
\hline & & & & (5) & 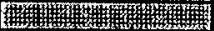 \\
\hline & & & & (1) & (1) \\
\hline & & & & 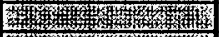 & 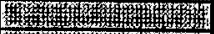 \\
\hline & & & & 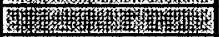 & (4) \\
\hline & & & & 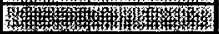 & 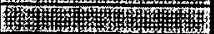 \\
\hline & & & & 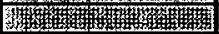 & W(1) \\
\hline & & & & 3 & (1) \\
\hline & & & & (4) & 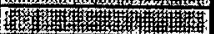 \\
\hline TOTAL B/A & (Hon & 13.6380 & 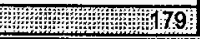 & 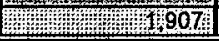 & Ka $\quad 2086$ \\
\hline
\end{tabular}

${ }^{1}$ Estimated Carryover Is NOT Included In Cost Baseline; Change Request For Actual Carryover Submitted After September 30, 1998. 
FAST FLUX TEST FACILITY

SUMMARY OF BUDGET AUTHORITY (BIA) BY YEAR BY PROJECT BASELINE SUMMARY (PBS)

FY 1999

(\$000s)

\begin{tabular}{|c|c|c|c|c|c|}
\hline MISSION WBS : & 2.0 & & & & \\
\hline - & & $\begin{array}{c}\text { TARGET } \\
\text { B/A }\end{array}$ & $\begin{array}{l}\text { CARRYOVER } \\
\text { FROM }\end{array}$ & 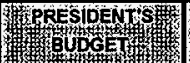 & 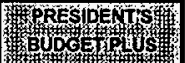 \\
\hline PBS TITLE & PBS NO & FY1998 & FY1998 & 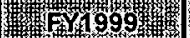 & 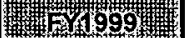 \\
\hline FFTF & RL-MS01 & - & - & 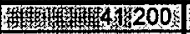 & 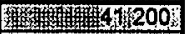 \\
\hline & & & & (1) & 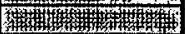 \\
\hline & & & & 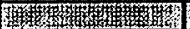 & 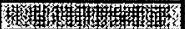 \\
\hline & & & & 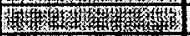 & (1) \\
\hline & & & & $y_{i}$ & 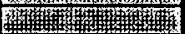 \\
\hline & & & & Y) & (1) \\
\hline & & & & 领 & (1) \\
\hline & & & . & (1) & 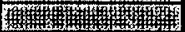 \\
\hline & & & & $\left(\mu^{\prime}\right.$ & (3) \\
\hline & & & & (3) & 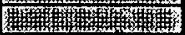 \\
\hline & & & & 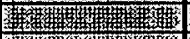 & 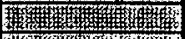 \\
\hline & & & & 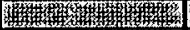 & 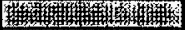 \\
\hline & & & & Yj(j) & 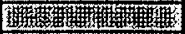 \\
\hline & & & & 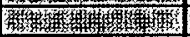 & צ' \\
\hline & & & & (2) & 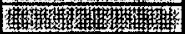 \\
\hline TOTAL:B/A & & 3 & 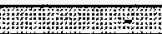 & $4 \quad 41,200$ & $3 \quad 41,200$ \\
\hline
\end{tabular}

'Estimated Carryover Is NOT Included In Cost Baseline; Change Request For Actual Carryover Submitted After September 30, 1998. 


\section{B.1 Advanced Reactors Transition (RL-TP11)}

\section{B.1.1.0 Advanced Reactors Transition Technical Baseline}

This section describes the technical baseline for this project. It identifies the mission, the end point targets, the site major facilities, technical logic, functions, requirements, and forecasts for this project.

\section{B.1.1.1 Advanced Reactors Transition Mission}

The Advanced Reactors Transition (ART) PBS is made up of three projects: The Plutonium Recycle Test Reactor (PRTR)/309 Building, the Nuclear Energy (NE) Legacies, and prior to FY1999, the Fast Flux Test Facility (FFTF) and Fuels and Materials Examination Facility (FMEF). The purpose of the ART projects is to safely transition assigned facilities to a deactivated state. The FFTF and FMEF were placed in standby and assigned to DOE-NE (PBS RL-MS01).

The Plutonium Recycle Test Reactor (PRTR)/309 Building, originally completed in 1960, provided an operating test reactor in the Hanford Works Plutonium Fuels Utilization Program to research and develop nuclear fuel technology. In 1962, the Plutonium Recycle Critical Facility (PRCF) was added to support the PRTR operation as a location where the reactivity values of fuel assemblies could be checked. Then in 1963, the Fuel Element Rupture Test Facility (FERTF) began operation in one fringe channel of the PRTR. The FERTF was used as a pilot irradiation facility to test new fuel element designs and new operating regimes. Reactor operations ceased in 1969 . Several uses of the facility continued until August of 1993, when the PRTR/309 Building facility was declared excess by DOE-NE. The transition of the building to the Environmental Restoration Contractor (ERC) will involve placing the facility in a configuration which reduces surveillance and maintenance costs to a minimum and meets acceptance criteria for turnover to the ERC.

The NE Legacies consist of non-nuclear faciities that were used in the development of the LMFBR programs and in related engineering studies. Some of the facilities contained sodium test loops that were used to study the properties of sodium heat transport systems and to investigate the behavior of mechanical components that would be operated in a sodium environment. Other facilities were used in training the FFTF operators prior to the FFTF becoming operational.

\section{B.1.1.2 Advanced Reactors Transition End Point Targets from Hanford Strategic Plan}

* Transition high cost surplus facilities to a low cost, stable, deactivated condition.

- Reuse facilities in the south 600 area for economic diversification where feasible.

\section{B.1.1.3 Advanced Reaciors Transition Major Facilities}

\section{B.1.1.3.1 309 Facility}

\section{B.1.1.3.1.1 309 Facility Description}

The 309 Building is a two story, steel framed building constructed in 1960 . This facility was built for use as the Plutonium Recovery Test Reactor (PRTR), but has been used by several other programs. It is currently closed. 


\section{B.1.1.3.1.2 309 Facility Facility Technical Logic:}

The Department of Energy (DOE), in partnership with its contractors, shall plan, acquire, operate, maintain, and dispose of physical assets as valuable national resources. Stewardship of these physical assets shall be accomplished in a cost-effective manner to meet the DOE mission. This shall incorporate industry standards, a graded approach, and performance objectives.

This diagram displays the primary work activities (functions) that are performed in each life cycle phase of the facility: The diagram also reflects the technical logic (functional flow) for the facility through its remaining life cycle phases.

Project responsibility for the life cycle phases of the 309 Facility components are assigned as follows:

Table B.1-1 Responsibility Assignment Matrix for 309 Facility

\begin{tabular}{|c|c|c|c|c|c|c|c|c|c|}
\hline \multirow{3}{*}{ Facility } & \multicolumn{9}{|c|}{ Life Cycle Phase* } \\
\hline & \multirow{2}{*}{$\begin{array}{l}\text { Program } \\
\text { Planning }\end{array}$} & \multirow{2}{*}{$\begin{array}{c}\text { Pre } \\
\text { Conceptual }\end{array}$} & \multirow[b]{2}{*}{ Conceptual } & \multicolumn{3}{|c|}{ Execute } & \multirow[b]{2}{*}{ O\&M } & \multicolumn{2}{|c|}{ Close Out } \\
\hline & & & & Design & Construction & Tumover & & Post Ops & D\&D \\
\hline 309 Facility & RL-TP11 & & & . & & & & $\begin{array}{l}\text { RL-IP11 } \\
\text { RL-ER05 } \\
\end{array}$ & RL-ER06 \\
\hline
\end{tabular}

- RL PBS Identifier Index;

RL-ER0S - Surveillance and Maintenance

RL-ER06 - Decontamination \& Decommissioning

RL-TP11 - Advanced Reactors Transition 
HNF-SP-1240

Rev: 1

9 September 1998

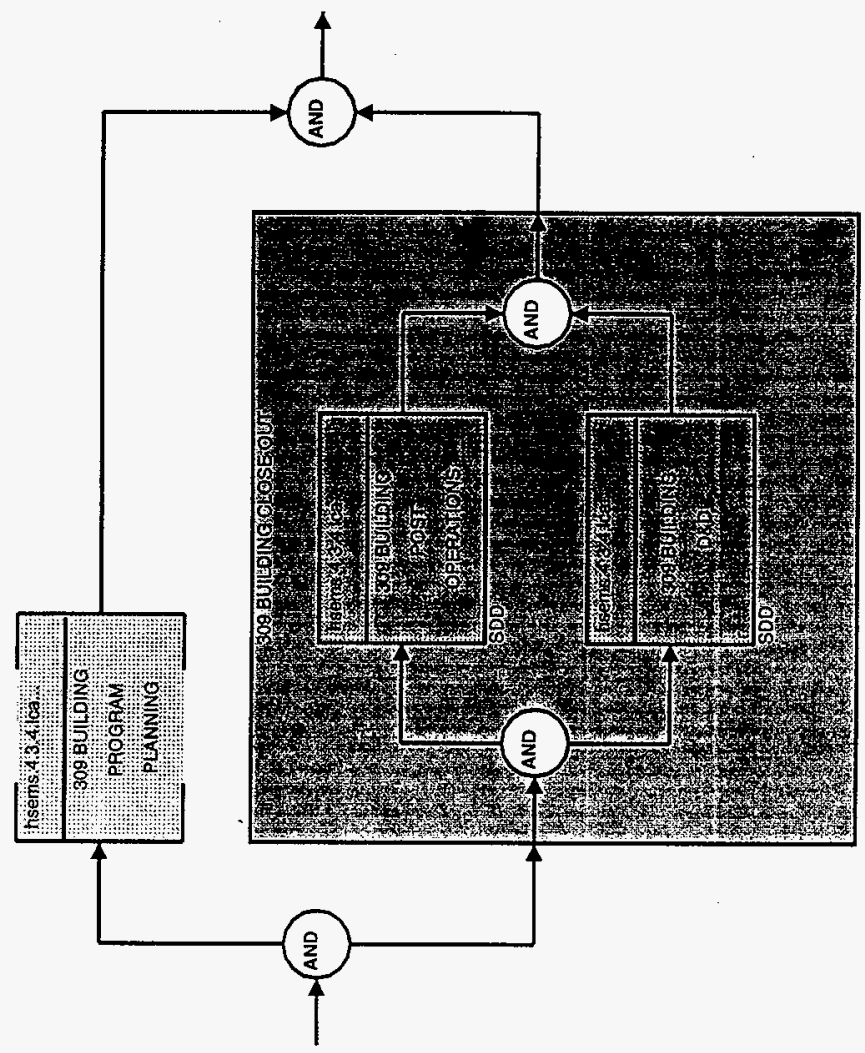

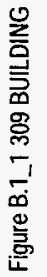




\section{B.1.1.3.1.3 309 Facility Life Cycle Functional Descriptions and Requirements}

The Life Cycle Functional Descriptions table describes the life cycle phases and the functions performed during each phase. The Life Cycle Requirements table describes the requirements that trace to the functions listed in the Life Cycle Functional Descriptions table.

Table B.1-2 309 Facility Life Cycle Functional Descriptions

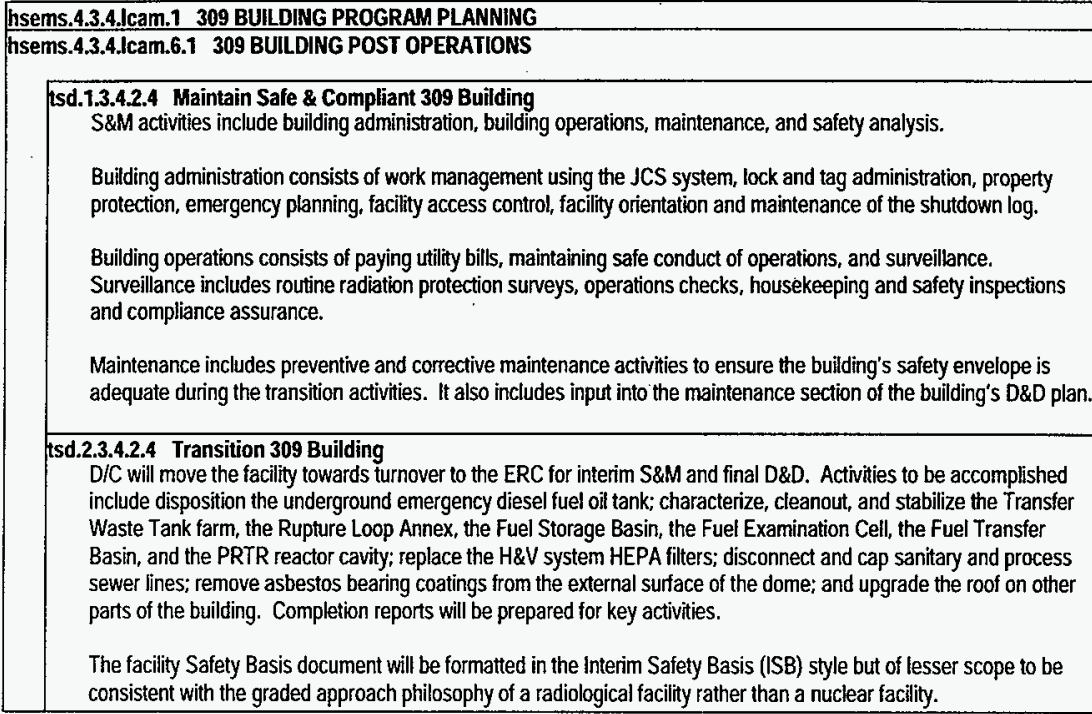

Table B.1-3 309 Facility Life Cycle Requirements

\begin{tabular}{|l|c|}
\hline \multicolumn{1}{|c|}{ Requirement } & Function \\
\hline The stabilizing and reconfiguring facilities for minimum S\&M including deactivation of non-essential utilities, \\
process systems, and other facility systems; modification of facility safety, ventilation, monitoring, electrical, and \\
utility systems; removal of resources and waste; and transfer of the facility to the ERC. Remaining active systems \\
shall be capable of operation and statusing from a location outside the facility so only quarterly personnel entry is \\
required. Facility electrical systems shall be reconfigured so only minimal portions can be operated as required to \\
support personnel entry. All facility reconfiguration shall be performed under Occupational Safety and Health \\
Administration construction requirements.
\end{tabular}


Table B.1-3 309 Facility Life Cycle Requirements (Continued)

\begin{tabular}{l}
\hline \multicolumn{1}{|c|}{ Requirement } \\
\hline The Contractor shall safely and efficiently manage the deactivation of facilities in the 300 Area whose mission \\
was the manufacture of fuels and test assemblies for the plutonium production, space power, and advanced \\
reactor programs. The facilities include among others, the $308,309,333$ Buildings, and associated facilities. \\
The program will disposition nuclear material stored in these facilities. As the material is removed, each facility \\
will be deactivated to reduce risk and attain the lowest surveillance and maintenance cost to a condition ready for \\
disposition. \\
The Contractor shall complete removal of the TRIGA test reactor nuclear fuel and shut down the 308 Building. \\
The contractor shall clean-up the nuclear waste and stabilize the 309 Building and surrounding area such that the \\
tlosure of the 309 Building can be accomplished.
\end{tabular}

\section{B.1.1.3.1.4 309 Facility Boundary Diagram}

This section identifies the other facilities (onsite and offsite) that have an interface (either input or output) with this facility.

Table B.1-4 309 Facility Boundary Diagram

\begin{tabular}{|l|c|c|}
\hline \multicolumn{1}{|c|}{ Major Input Interfaces } & Facility & \multicolumn{1}{c|}{ Major Outputinterfaces } \\
\hline $\begin{array}{l}\text { External Interiaces } \\
\text { Hanford Legacy } \\
\text { Hanford Site Environmental System Interfaces } \\
\text { S600 Electrical Distribution }\end{array}$ & 309 Facility & $\begin{array}{l}\text { External Interfaces } \\
\text { Hazardous Waste Disposal Contracts } \\
\text { Offsite Landfitl } \\
\text { Hanford Site Environmental System Interfaces } \\
300 \text { Area Treated Effluent Disposal Facility } \\
\text { Central Waste Complex } \\
\text { Low-Level Waste Burial_Grounds }\end{array}$ \\
\hline
\end{tabular}

\section{B.1.1.3.1.5 309 Facility Interface Descriptions and Summary Level Forecasts}

This section contains the material, waste, and infrastructure forecasts for this facility. It identifies the interface type, the period of time for the forecasts, the life cycle total forecast value, and the execution year forecast quantity.

\section{OFFSITE INPUTS}

Table B.7-5 Offsite Inputs for 309 Facility

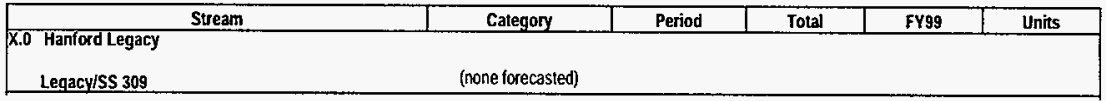

\section{ONSITE INPUTS}

Table B.1-6 Onsite Inputs for 309 Facility

\begin{tabular}{|c|c|c|c|c|c|}
\hline Stream & Category & Period & Total & FY99 & Units \\
\hline \multicolumn{6}{|c|}{ hisems.5.1.4.4 S600 Electrical Distribution } \\
\hline Electricity for 399 & Electricity & & & 293.0 & MW-Hr \\
\hline
\end{tabular}

\section{OFFSITE OUTPUTS}


Table B.1-7 Offsite Outputs for 309 Facility

\begin{tabular}{|c|c|c|c|c|c|}
\hline Stream & Category & Period & Total & FY99 & Units \\
\hline \multicolumn{6}{|l|}{ X Hazardous Waste Disposal Contracts } \\
\hline 309 Asbestos & Asbestos & $1999-1999$ & 139.0 & 139.0 & cubic meters \\
\hline$X$ Ofisite Landfal & & & & & \\
\hline 309 Building Sanitary Solid Waste & Sanitary Solid Waste & $1999-2003$ & 10.0 & 2.0 & cubic meters \\
\hline
\end{tabular}

\section{ONSITE OUTPUTS}

Table B.1-8 Onsite Outputs for 309 Facility

\begin{tabular}{|c|c|c|c|c|c|}
\hline Stream & Category & Period & Total & FYg9 & Units \\
\hline \multicolumn{6}{|l|}{ Ssems.2.3.5.1 Central Waste Complex } \\
\hline $\begin{array}{l}\text { PRTR, CH-LLMWH } \\
\text { PRTR, CH-TRU }\end{array}$ & $\begin{array}{c}\text { CH LLMWI } \\
\text { (none forecasted) }\end{array}$ & $2000-2003$ & 1.28 & & cubic meters \\
\hline hsems.2.4.1.1 Low-Level Waste Bumial Gounds & & & & & \\
\hline $\begin{array}{l}\text { PRTR, CH-LLW- } \\
\text { PRTR, CH-LLW-\#I }\end{array}$ & $\begin{array}{c}\text { CH LLW I } \\
\text { (none forecasted) }\end{array}$ & $1999-2003$ & 19.7 & 0.0 & cubic meters \\
\hline $\begin{array}{l}\text { hisems.4.2.1.1 300 Area Treated Effluent Disposal Facility } \\
\text { 309 Building Industria! Waste Water Transfer }\end{array}$ & (none forecasted) & & & & \\
\hline
\end{tabular}

\section{B.1.1.3.2 NE Legacy Facilities}

\section{B.1.1.3.2.1 NE Legacy Facilities Description}

The activities associated with the sodium legacy facilities were originally performed to support the Liquid Metal Fast Breeder Reactor (LMFBR) Program for eventual commercial use. Service and auxiliary buildings, and facilities are provided as required for operational and administrative control of each facility.

\section{B.1.1.3.2.2 NE Legacy Facilities Facility Technical Logic:}

This diagram displays the primary work activities (functions) that are performed in each life cycle phase of the facility. The diagram also reflects the technical logic (functional flow) for the facility through its remaining life cycle phases.

Project responsibility for the life cycle phases of the NE Legacy Facilities components are assigned as follows:

Table B.7-9 Responsibility Assignment Matrix for NE Legacy Facilities

\begin{tabular}{|c|c|c|c|c|c|c|c|c|c|}
\hline \multirow{3}{*}{ Facility } & \multicolumn{9}{|c|}{ Life Cycle Phase * } \\
\hline & \multirow{2}{*}{$\begin{array}{l}\text { Program } \\
\text { Planning }\end{array}$} & \multirow{2}{*}{$\begin{array}{c}\text { Pre } \\
\text { Conceptual }\end{array}$} & \multirow[b]{2}{*}{ Conceptual } & \multicolumn{3}{|c|}{ Execute } & \multirow[b]{2}{*}{$0 \& \mathrm{M}$} & \multicolumn{2}{|c|}{ Close Out } \\
\hline & & & & Design & Construction & Tumover & & Post Ops & D\&O \\
\hline NE Legacy Facilities & RL-IP11 & & & & & & & RL-TP11 & RL-ERO5 \\
\hline
\end{tabular}

- RL PBS Identifier Index:

RL-ER05 - Surveillance and Maintenance RL-TP11 - Advanced Reactors Iransition 
HNF-SP-1240

Rev: 1

9 September 1998

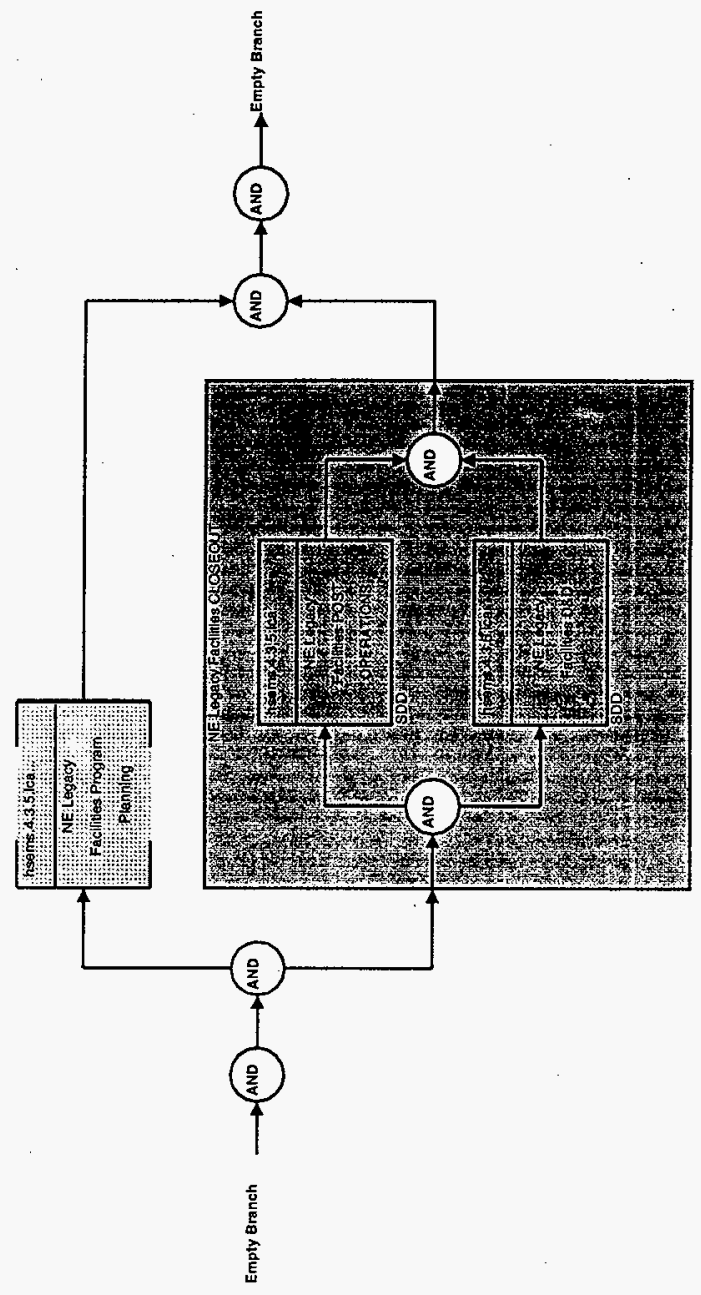

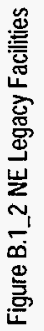




\section{B.1.1.3.2.3 NE Legacy Facilities Life Cycle Functional Descriptions and Requirements}

The Life Cycle Functional Descriptions table describes the life cycle phases and the functions performed during each phase. The Life Cycle Requirements table describes the requirements that trace to the functions listed in the Life Cycle Functional Descriptions table.

\section{Table B.7-10 NE Legacy Facilities Life Cycle Functional Descriptions}

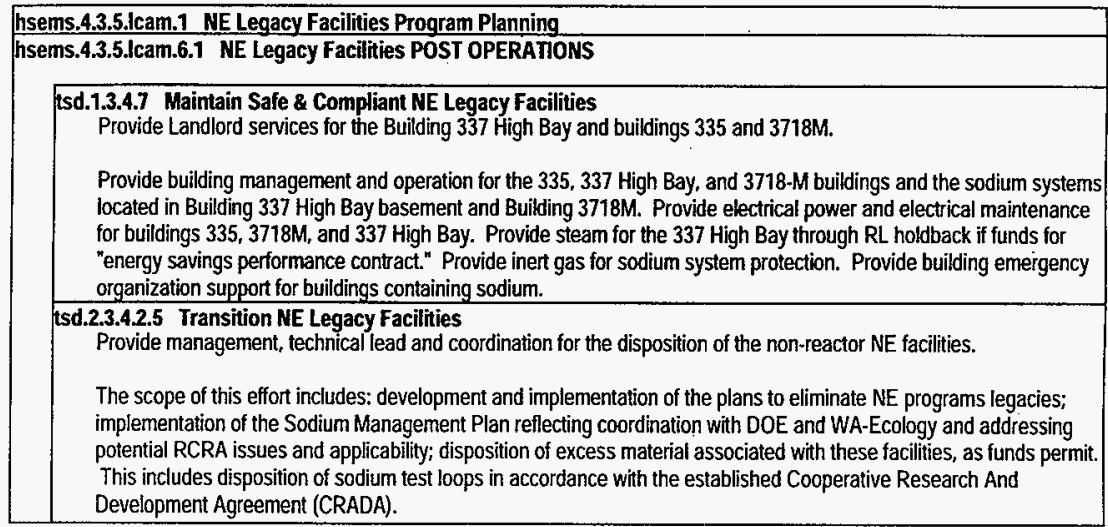

Table B.1-11 NE Legacy Facilities Life Cycle Requirements

\begin{tabular}{|l|l|}
\hline \multicolumn{1}{|c|}{ Requirement } & Function \\
\hline Disposal of Alkali Metal Test Loops will comply with DOE/EA-0987 & tsd.1.3.4.7 \\
\hline The stabilizing and reconfiguring facilities for minimum S\&M including deactivation of non-essential utilities, & tsd.2.3.4.2.5 \\
process systems, and other facility systems; modification of facility safety, ventilation, monitoring, electrical, and \\
utility systems; removal of resources and waste; and transfer of the facility to the ERC. Remaining active systems \\
shall be capable of operation and statusing from a location outside the facility so only quarterly personnel entry is \\
required. Facility electrical systems shall be reconfigured so only minimal portions can be operated as required to \\
support personnel entry. All facility reconfiguration shall be performed under Occupational Safety and Health \\
\begin{tabular}{ll} 
Administration construction requirements. \\
\hline Ensuring final facility configurations do not preclude D\&D activities.
\end{tabular} \\
\hline High cost surplus facilties and systems shall be transitioned to a low cost, stable, deactivated condition. \\
\hline Facilities and systems shall be made available for other uses. & tsd.2.3.4.2.5 \\
\hline South 600 Area facilities shall be surveilled and maintained within the approved safety envelope & tsd.2.3.4.4.2.5 \\
\hline
\end{tabular}

\section{B.1.1.3.2.4 NE Legacy Facilities Boundary Diagram}

This section identifies the other facilities (onsite and offsite) that have an interface (either input or output) with this facility. 
Table B.1-12 NE Legacy Facilities Boundary Diagram

\begin{tabular}{|c|c|c|}
\hline Major Input nterfaces & Facility & Maior Outnut Interfaces \\
\hline $\begin{array}{l}\text { External Interfaces } \\
\text {-None- } \\
\text { Hanford Site Environmental System interfaces } \\
\text { Electrical Distribution System } \\
\text { General Purpose Shops } \\
\text { Telecommuniçations System }\end{array}$ & NE Legacy Facilities & $\begin{array}{l}\text { External Interfaces } \\
\text {-None- } \\
\text { Hanford Site Environmental System Interfaces } \\
\text { Sanitary Landfill }\end{array}$ \\
\hline
\end{tabular}

\section{B.1.1.3.2.5 NE Legacy Facilities Interface Descriptions and Summary Level Forecasts}

This section contains the material, waste, and infrastructure forecasts for this facility. It identifies the interface type, the period of time for the forecasts, the life cycle total forecast value, and the execution year forecast quantity.

\section{OFFSITE INPUTS}

-None-

\section{ONSITE INPUTS}

Table B.1-13 Onsite Inputs for NE Legacy Facilities

\begin{tabular}{|c|c|c|c|c|c|}
\hline Stream & Category & Period & Total & FY99 & Units \\
\hline \multicolumn{6}{|l|}{ hsems.5.1.4 Electrical Distribution System } \\
\hline Electricity for NE Legacy Facilities & Electricity & & & 1320.0 & MW-H \\
\hline \multicolumn{6}{|l|}{ hsems.5.1.5 Telecommunications System } \\
\hline Telecommusications for NESF & $\begin{array}{l}\text { Voice Communications } \\
\text { Service }\end{array}$ & & & 5.0 & ea \\
\hline \multicolumn{6}{|l|}{ hsems.5.2.3 General Purpose Shops } \\
\hline Shops for NESF & (none forecasted) & & & & \\
\hline
\end{tabular}

\section{OFFSITE OUTPUTS}

-None-

\section{ONSITE OUTPUTS}

Table B.1-14 Onsite Outputs for NE Legacy Facilities

\begin{tabular}{|c|c|c|c|c|c|}
\hline Stream & Category & Period & Fotal & FY99 & Units \\
\hline $\begin{array}{l}\text { hsems.5.1.6 Sanitary Landifl } \\
\text { Landfill for NE Legacy Facilities }\end{array}$ & Sanitary Solid Waste & $1999-2004$ & 42.0 & 7.0 & cubic meters \\
\hline
\end{tabular}

\section{B.1.1.4 Drivers for Advanced Reactors Transition}

\section{Table B.1-15 Source Documents for Advanced Reactors Transition}

Name

DE-AC06-96RL13200

DOE/EA-0987

DOE/EIS-0222D

DOE/RL-96-92
Tinle

Project Hanford Management Contract, Fluor Daniel Hanford, Inc.

Disposition of Alkali Metal Test Loops, Hanford Site, Richland, Washington

Draft Hanford Remedial Action Environmental Impact Statement and Comprehensive Land Use Plan

Hanford Strategic Plan 
Table B.1-15 Source Documents for Advanced Reactors Transition (Continued)

Name

DOE/RL-97-55
Iitle

Hanford Site Environmental Management Specification 
B.1.2.0 Advanced Reactors Transition Work Breakdown Structure (WBS)

\section{B.1.2.1 Advanced Reactors Transition WBS Hierarchy}

\begin{tabular}{lll}
\hline RLPBS & RL WBS & Tille \\
\hline RL-TP11 & 1.12 .01 & Advanced Reactors Transition \\
& 1.12 .01 .01 & NE Legacy Facilities \\
& 1.12 .01 .01 .01 & Maintain Safe \& Compliant NE Legacy Facilities \\
& 1.12 .01 .01 .02 & Transition NE Legacy Facilities \\
& 1.12 .01 .02 & 309 Facility \\
& 1.12 .01 .02 .01 & Maintain Safe \& Compliant 309 Building \\
& 1.12 .01 .02 .02 & Transition 309 Building \\
\hline
\end{tabular}

B.1.2.2 Advanced Reactors Transition WBS Dictionary

The following pages contain the WBS dictionary for RL-TP11 
1. Dictionary Title Maintain Safe \& Compliant NE Legacy Facilities

2. Date

3. PBS Number 4. Dict Rev

5. WBS No.

6. B \& R No. 14 Auqust 1998

1.12.01.01.01 EX04J102

7. Baseline CR No.

8. Organization Name

Advanced Reactors Transition

9. Scope of Work

Provide Landlord services for the Building 337 High Bay and buildings 335 and $3718 \mathrm{M}$.

Provide building management and operation for the 335, 337 High Bay, and 3718-M buildings and the sodium systems located in Building 337 High Bay basement and Building 3718M. Provide electrical power and electrical maintenance for buildings $335,3718 \mathrm{M}$, and 337 High Bay. Provide steam for the 337 High Bay through RL holdback if funds for "energy savings performance contract." Provide inert gas for sodium system protection. Provide building emergency organization support for buildings containing sodium.

This WBS covers work necessary to support satisfying the following technical baseline requirements for the Hanford clean up mission:

- Disposal of Alkali Metal Test Loops will comply with DOE/EA-0987

South 600 Area facilities shall be surveilled and maintained within the approved safety envelope 


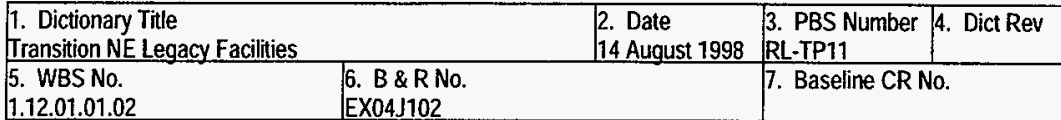

8. Organization Name

Advanced Reactors Transition

9. Scope of Work

Provide management, technical lead and coordination for the disposition of the non-reactor NE facilities.

The scope of this effort includes: development and implementation of the plans to eliminate NE programs legacies; implementation of the Sodium Management Plan reflecting coordination with DOE and WA-Ecology and addressing potential RCRA issues and applicability; disposition of excess material associated with these facilities, as funds permit. This includes disposition of sodium test loops in accordance with the established Cooperative Research And Development Agreement (CRADA).

This WBS covers work necessary to support satisfying the following technical baseline requirements for the Hanford clean up mission:

- $\quad$ The stabilizing and reconfiguring facilities for minimum S\&M including deactivation of non-essential utilities, process systems, and other facility systems; modification of facility safety, ventilation, monitoring, electrical, and utility systems; removal of resources and waste; and transfer of the facility to the ERC. Remaining active systems shall be capable of operation and statusing from a location outside the facility so only quarterly personnel entry is required. Facility electrical systems shall be reconfigured so only minimal portions can be operated as required to support personnel entry. All facility reconfiguration shall be performed under Occupational Safety and Health Administration construction requirements. Ensuring final facility configurations do not preclude D\&D activities.

High cost surplus facilties and systems shall be transitioned to a low cost, stable, deactivated condition. Facilities and systems shall be made available for other uses. 
1. Dictionary Title

Maintain Safe \& Compliant 309 Building

5. WBS No.

1.12.01.02.01

8. Organization Name

Advanced Reactors Transition

9. Scope of Work

S\&M activities include building administration, building operations, maintenance, and safety analysis.

Building administration consists of work management using the JCS system, lock and tag administration, property protection, emergency planning, facility access control, facility orientation and maintenance of the shutdown log.

Building operations consists of paying utility bills, maintaining safe conduct of operations, and surveillance. Surveillance includes routine radiation protection surveys, operations checks, housekeeping and safety inspections and compliance assurance.

Maintenance includes preventive and corrective maintenance activities to ensure the building's safety envelope is adequate during the transition activities. It also includes input into the maintenance section of the building's D\&D plan.

This WBS covers work necessary to support satisfying the following technical baseline requirements for the Hanford clean up mission:

- $\quad$ South 600 Area gaseous effluent releases shatl be monitored

- South 600 Area facilities shall be surveilled and maintained within the approved safety envelope 


\begin{tabular}{|c|c|c|c|}
\hline \begin{tabular}{|l|} 
1. Dictionary Títle \\
Transition 309 Building
\end{tabular} & $\begin{array}{l}\text { 2. Date } \\
9 \text { September } \\
1998\end{array}$ & $\begin{array}{l}\text { 3. PBS Number } \\
\text { RL-TP11 }\end{array}$ & 4. Dict Rev \\
\hline $\begin{array}{l}\text { 5. WBS No. } \\
1.12 .01 .02 .02\end{array}$ & & 7. Baseline $C R$ & \\
\hline
\end{tabular}

8. Organization Name

Advanced Reactors Transition

9. Scope of Work

$D / C$ will move the facility towards turnover to the ERC for interim S\&M and final D\&D. Activities to be accomplished include disposition the underground emergency diesel fuel oil tank; characterize, cleanout, and stabilize the Transfer Waste Tank farm, the Rupture Loop Annex, the Fuel Storage Basin, the Fuel Examination Cell, the Fuel Transfer Basin, and the PRTR reactor cavity; replace the H\&V system HEPA filters; disconnect and cap sanitary and process sewer lines; remove asbestos bearing coatings from the external surface of the dome; and upgrade the roof on other parts of the building. Completion reports will be prepared for key activities.

The facility Safety Basis document will be formatted in the Interim Safety Basis (iSB) style but of lesser scope to be consistent with the graded approach philosophy of a radiological facility rather than a nuclear facility.

This WBS covers work necessary to support satisfying the following technical baseline requirements for the Hanford clean up mission:

- The stabilizing and reconfiguring facilities for minimum S\&M including deactivation of non-essential utilities, process systems, and other facility systems; modification of facility safety, ventilation, monitoring, electrical, and utility systems; removal of resources and waste; and transfer of the facility to the ERC. Remaining active systems shall be capable of operation and statusing from a location outside the facility so only quarterly personnel entry is required. Facility electrical systems shall be reconfigured so only minimal portions can be operated as required to support personnel entry. All facility reconfiguration shall be performed under Occupational Safety and Health Administration construction requirements.

Ensuring final facility configurations do not preciude D\&D activities.

High cost surplus facilties and systems shall be transitioned to a low cost, stable, deactivated condition. Facilities and systems shall be made availabie for other uses.

Facilities shall be transitioned to the surveillance and maintenance phase when no longer required to support the site mission.

The Contractor shali safely and efficiently manage the deactivation of facilities in the 300 Area whose mission was the manufacture of fuels and test assemblies for the plutonium production, space power, and advanced reactor programs. The facilities include among others, the 308, 309, 333 Buildings, and associated facilities. The program will disposition nuclear material stored in these facilities. As the material is removed, each facility will be deactivated to reduce risk and attain the lowest surveillance and maintenance cost to a condition ready for disposition.

The Contractor shall complete removal of the TRIGA test reactor nuclear fuel and shut down the 308 Building. The contractor shall clean-up the nuclear waste and stabilize the 309 Building and surrounding area such that the closure of the 309 Building can be accomplished. 
HNF-SP-1240

Rev. 1

B.1.2.3 Advanced Reactors Transition Responsibility Assignment Matrix

\begin{tabular}{|l|l|l|}
\hline WBS Number & Title & Responsible Manager \\
\hline 1.12 .01 & Advanced Reactors Transition & $\begin{array}{l}\text { D. B. Klos, FDH } \\
\text { E. F. Loika, BWHC }\end{array}$ \\
\hline 1.12 .01 .01 & NE Legacy Facilities & W. F. Brehm \\
\hline 1.12 .01 .01 .01 & $\begin{array}{l}\text { Maintain Safe \& Compliant NE Legacy } \\
\text { Facilities }\end{array}$ & W. F. Brehm \\
\hline 1.12 .01 .01 .02 & Transition NE Legacy Facilities & W. F. Brehm \\
\hline 1.12 .01 .02 & 309 Facility & I. L. Metcalf \\
\hline 1.12 .01 .02 .01 & Maintain Safe \& Compliant 309 Building & I. L. Metcalf \\
\hline 1.12 .01 .02 .02 & Transition 309 Building & I. L. Metcalf \\
\hline
\end{tabular}




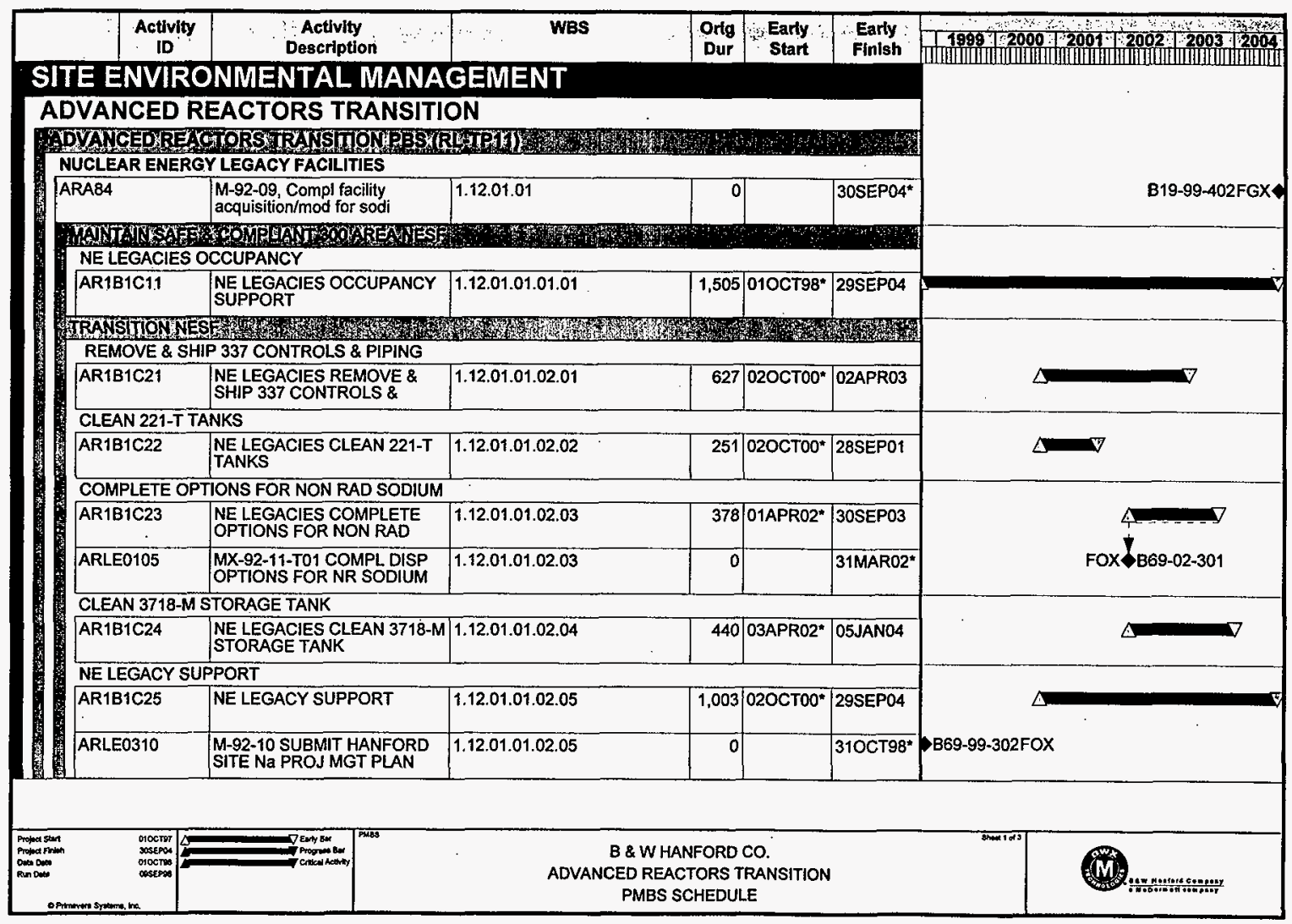




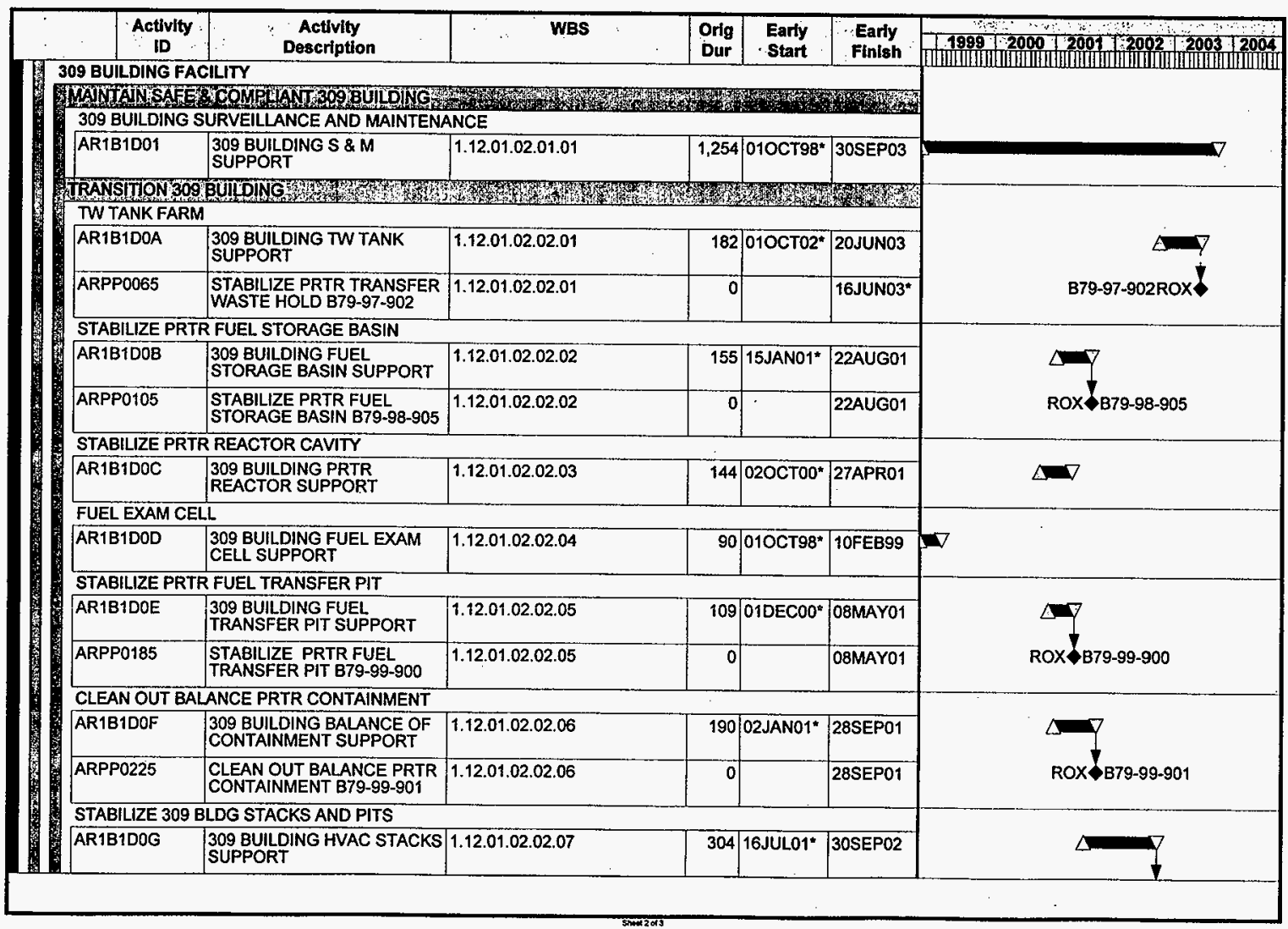




\begin{tabular}{|c|c|c|c|c|c|c|c|}
\hline & $\begin{array}{l}\text { Activity } \\
\text { ID }\end{array}$ & $\begin{array}{c}\text { Actlvity } \\
\text { Description }\end{array}$ & WBS & $\begin{array}{l}\text { Orig } \\
\text { Dur }\end{array}$ & $\begin{array}{l}\text { Early } \\
\text { Start }\end{array}$ & $\begin{array}{l}\text { Earty } \\
\text { Finish }\end{array}$ & 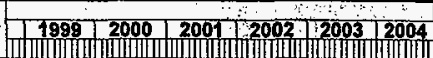 \\
\hline \multirow[t]{3}{*}{ 窗 } & ARPP0275 & $\begin{array}{l}\text { STABILIZE } 309 \text { BLDG } \\
\text { STACKS AND PITS }\end{array}$ & 1.12 .01 .02 .02 .07 & 0 & & 30 SEP02 & ROX B B $79-99-902$ \\
\hline & \multicolumn{6}{|c|}{ FACILITY DOCUMENT UPDATES } & \multirow[b]{2}{*}{$\Delta$} \\
\hline & AR1B1DOH & $\begin{array}{l}\text { 309 BUILDING FACILITY } \\
\text { DRAWING UPDATES }\end{array}$ & 1.12 .01 .02 .02 .08 & 752 & 020CTO0* & 30SEP03 & \\
\hline \multirow{3}{*}{$y^{2}$} & TRANSITION BI & DG 309 TO SHUTOOWN & & & & & \multirow{5}{*}{$\underbrace{\Delta}_{\mathrm{ROX} \gamma_{\mathrm{B} 79-99-903}}$} \\
\hline & AR1B1D0J & $\begin{array}{l}309 \text { BUILDING TRANSITION } \\
\text { TO SHUTDOWN }\end{array}$ & 1.12 .01 .02 .02 .09 & 1,109 & O1FEB99* & 30JUN03 & \\
\hline & ARPP0501 & DOME ROOF REPAIR & 1.12 .01 .02 .02 .09 & 125 & 01FEB99 & 29JUL.99 & \\
\hline \multirow{2}{*}{ 畜 } & ARPP0503 & $\begin{array}{l}309 \text { CONTAINMENT DOME } \\
\text { REPAIR }\end{array}$ & 1.12 .01 .02 .02 .09 & 0 & & 29JUL99 & \\
\hline & ARPP0510 & $\begin{array}{l}\text { TRANSITION BUILDING } 309 \\
\text { TO SHUTDOWN B79-01-901 }\end{array}$ & 1.12 .01 .02 .02 .09 & 0 & & 30JUN03* & \\
\hline
\end{tabular}




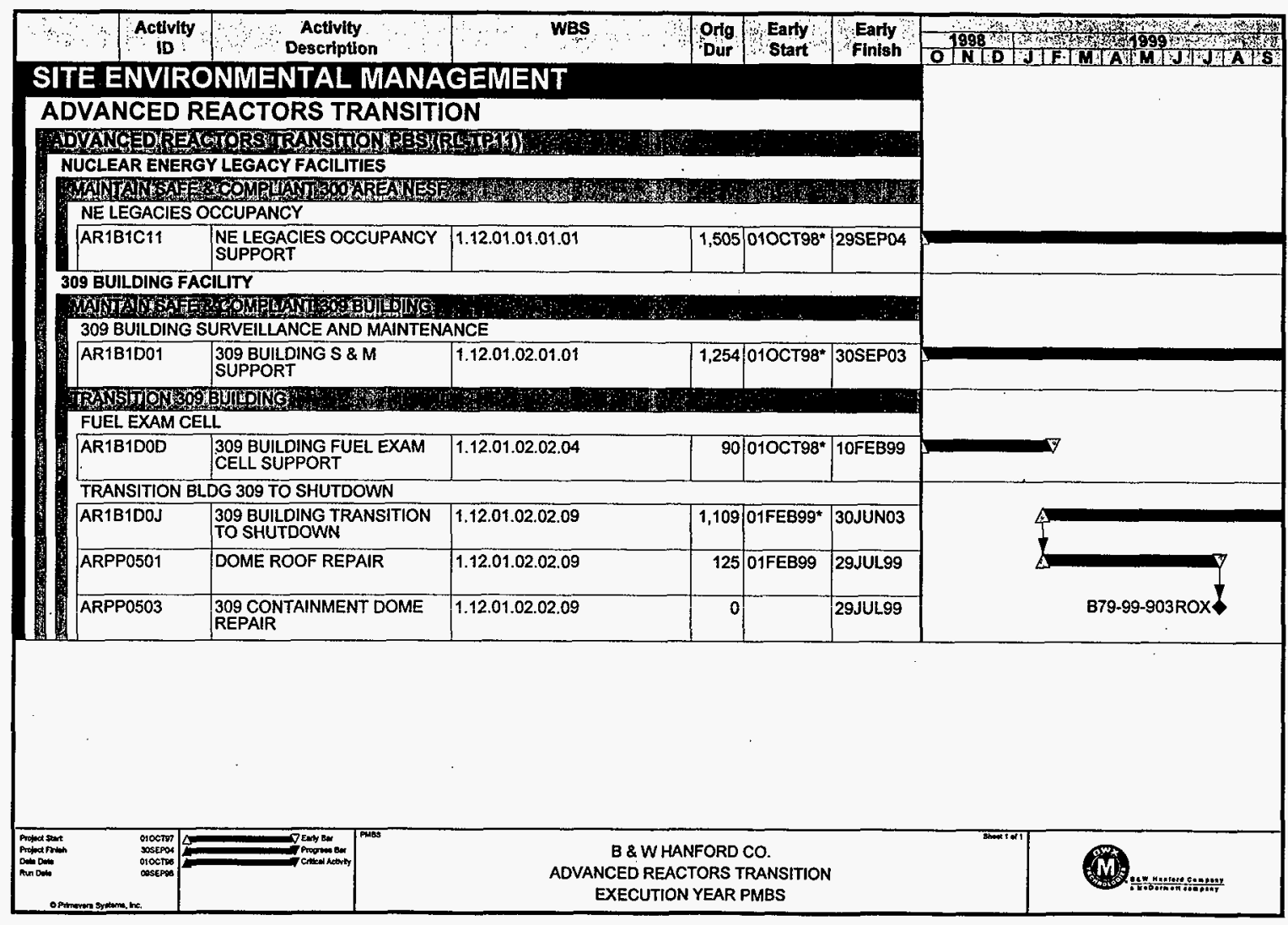


IPA-MS TPA MS

NUMBER TYPE LEVEL (...........

THE L......

MS TITLE

SUBMIT RANFORD SITE SOOIUM MANAGEMENT PLAN TO ECOLOGY

COMPLETE ACQUISITION FACILITIES DISPOSAL OF HANFORD SITE SODIUM COMPLETE DISPOSITION OPIIONS FOR HANFORD SITE NONRADIOACTIVE NA TRANSITION BLDG 309 TO SHUTDOHN STATUS STABILIZE THE PRTR FUEL SIORAGE BASIN STABILIZE THE PRTR FUEL TRANSFER PIT CLEAN OUT THE BALANCE OF THE PRTR CONTAIRMENT STABILIZE THE 309 BUILOING STACK AND PITS STABILIZE THE PRTR TRANSFER HASTE HOLDING TANKS

RL 309 CONTAINMENT DOME REPAIR
-...-DATES-........

PLANMED TPA/DNFSB

TYPE BASELINE

$10 / 31 / 98$

COMMIT

DNFSB TIP -....... ..... ...

$10 / 31 / 98$

$12 / 31 / 49$

$3 / 31 / 02$

$6 / 30 / 03$

$8 / 22 / 01$

$5 / 08 / 01$

$9 / 28 / 01$

$9 / 30 / 02$

$6 / 16 / 03$

OTH 7/29/99

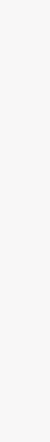




\section{PHMC}

MILESTONE DESCRIPTION SHEET

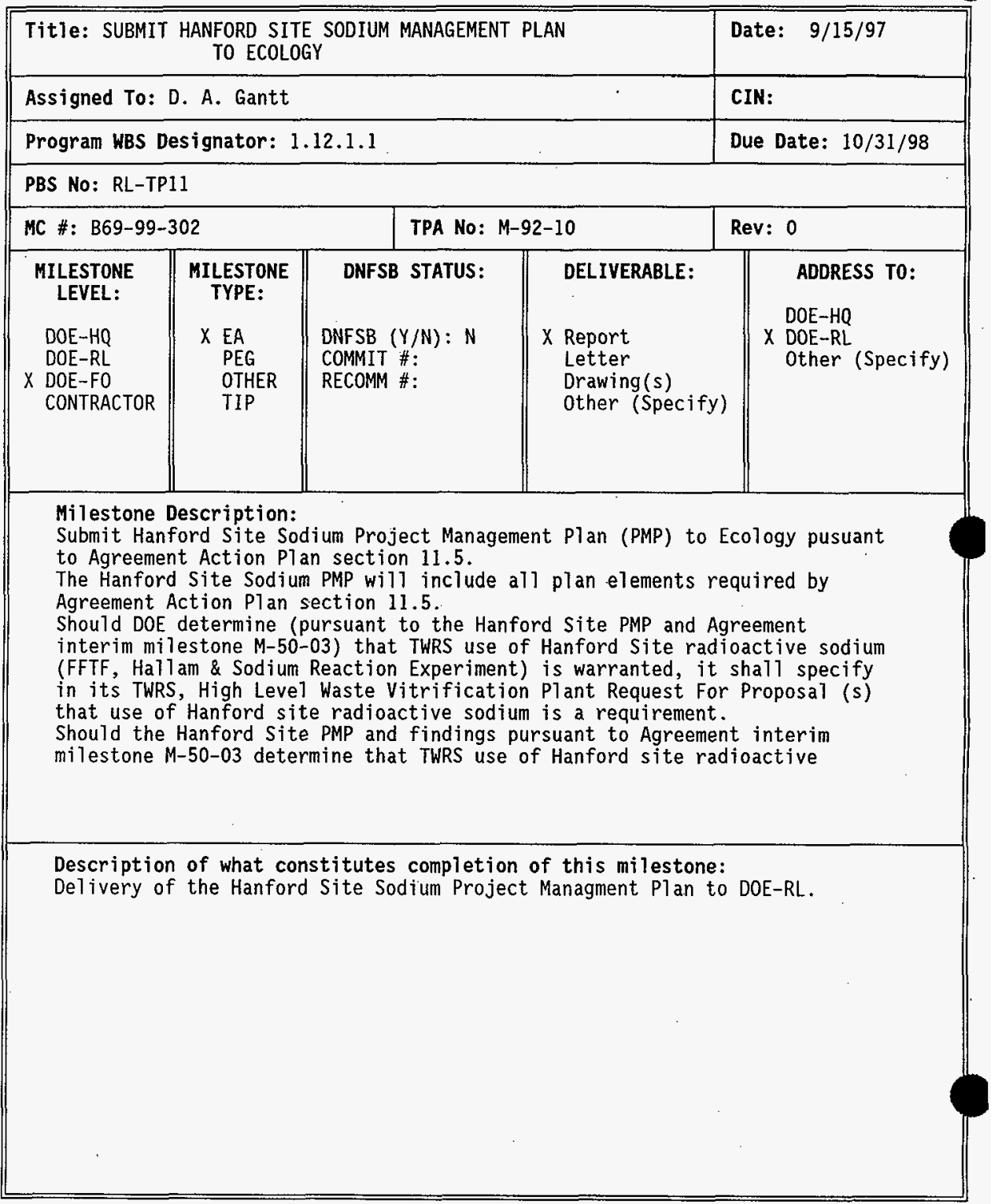




\section{PHMC}

\section{MILESTONE DESCRIPTION SHEET}

Program WBS Designator: 1.12.1.1

MC \#: B69-99-302

Milestone description: (con't)

sodium is not warranted DOE shall issue accompanying proposed Agreement

change requests for alternate Hanford Site radioactive sodium disposition

(e.g., necessary milestones and target dates associated with the

construction of the sodium reaction facility). See also Agreement target date $M-81-02-T 01$. 


\section{PHMC}

MILESTONE DESCRIPTION SHEET

\begin{tabular}{|c|c|c|c|c|}
\hline \multicolumn{4}{|c|}{$\begin{array}{c}\text { Title: COMPLETE ACQUISITION FACILITIES DISPOSAL OF } \\
\text { HANFORD SITE SODIUM }\end{array}$} & Date: $9 / 15 / 97$ \\
\hline \multicolumn{4}{|c|}{ Assigned To: D. A. Gantt } & CIN: \\
\hline \multicolumn{4}{|c|}{ Program WBS Designator: 1.12 .1 .1} & Due Date: $12 / 31 / 49$ \\
\hline \multicolumn{5}{|c|}{ PBS No: RL-TP11 } \\
\hline \multicolumn{2}{|c|}{ MC \#: B19-99-402 } & \multicolumn{2}{|c|}{ TPA No: M-92-09 } & Rev: 0 \\
\hline $\begin{array}{l}\text { MILESTONE } \\
\text { LEVEL: } \\
\text { DOE-HQ } \\
\text { DOE-RL } \\
\text { X DOE-FO } \\
\text { CONTRACTOR }\end{array}$ & $\begin{array}{l}\text { MILESTONE } \\
\text { TYPE: } \\
\text { X EA } \\
\text { PEG } \\
\text { OTHER } \\
\text { TIP }\end{array}$ & $\begin{array}{l}\text { DNFSB STATUS: } \\
\text { DNFSB }(Y / N): N \\
\text { COMMIT \#: } \\
\text { RECOMM \#: }\end{array}$ & $\begin{array}{l}\text { DELIVERABLE: } \\
\text { X Report } \\
\text { Letter } \\
\text { Drawing(s) } \\
\text { Other (Specify) }\end{array}$ & $\begin{array}{l}\text { ADDRESS TO: } \\
\text { DOE-HQ } \\
\times \text { DOE-RL } \\
\text { Other (Specify) }\end{array}$ \\
\hline \multicolumn{5}{|c|}{$\begin{array}{l}\text { Milestone Description: } \\
\text { Complete acquisition of new facilities, modification of existing } \\
\text { facilities, and/or modification of planned facilities necessary for } \\
\text { storage, treatment/processing, and disposal of Hanford site sodium. }\end{array}$} \\
\hline \multicolumn{5}{|c|}{$\begin{array}{l}\text { Description of what constitutes completion of this milestone: } \\
\text { Complete acquisition of new facilities, modification of existing } \\
\text { facilities, and/or modification of planned facilities necessary for } \\
\text { storage, treatment/processing, and disposal of Hanford site sodium. }\end{array}$} \\
\hline
\end{tabular}




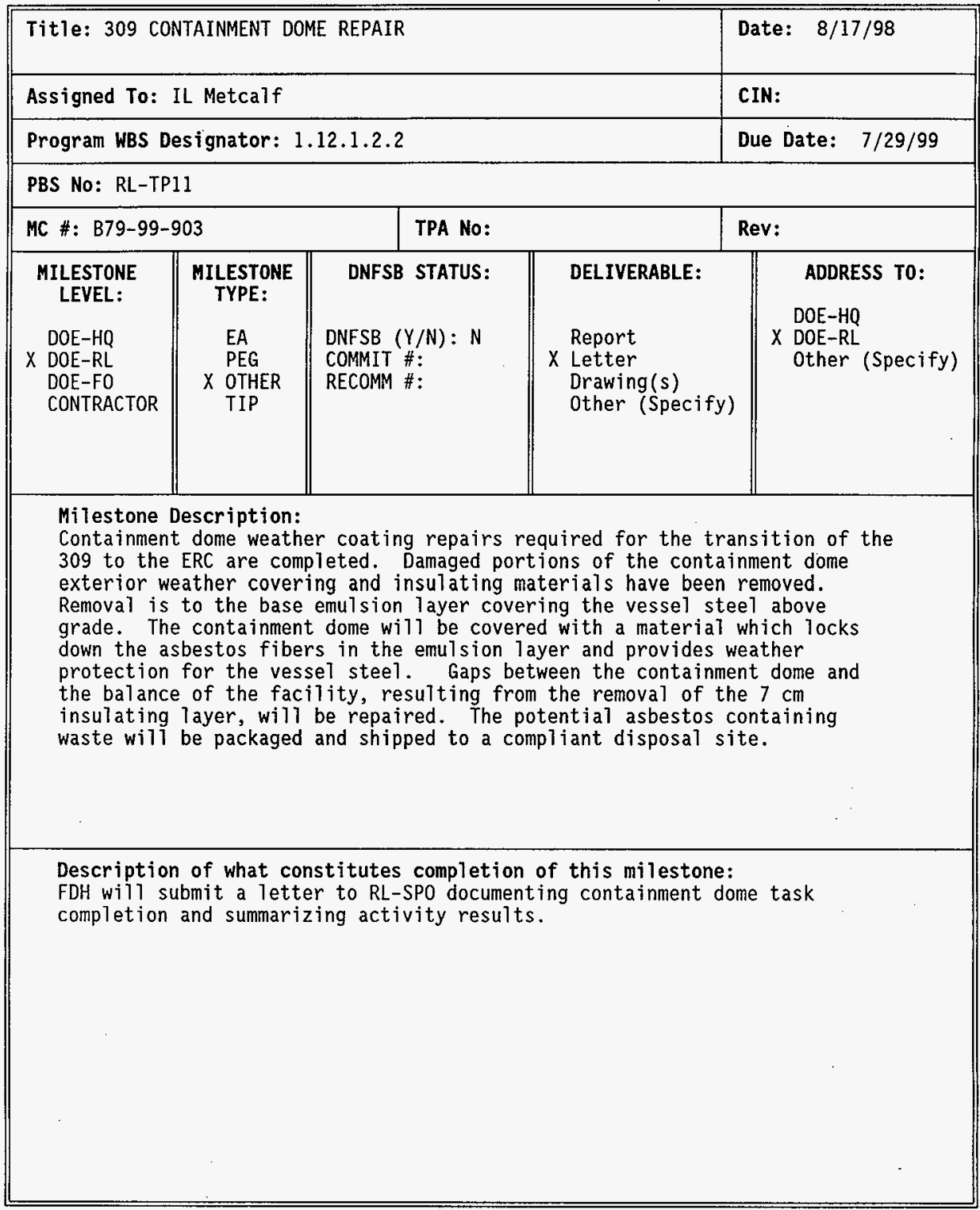


ADVANCED REACTORS TRANSITION

LIFE CYCLE COST BASELINE (BCWS) BY YEAR BY FUND TYPE

BY PROJECT BASELINE SUMMARY (PBS)

FY 1999

\begin{tabular}{|r|r|}
\hline PROJECT WBS: & $\mathbf{1 . 1 2 . 1}$ \\
\hline PBS NO: & RL-TP11 \\
(\$000s)
\end{tabular}

PBS TITLE: ADVANCED REACTORS TRANSITION

\begin{tabular}{|c|c|c|c|c|c|c|c|c|c|c|c|}
\hline PBS TITLE: & ADVANCEDR & REACTORS TR & ANSITION & & & & & & & & SUBTOT \\
\hline FUND TYPE & FY1997 & FY1998 & 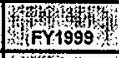 & FY2000 & FY2001 & FY2002 & FY2003 & FY2004 & FY2005 & FY2006 & $\begin{array}{l}\text { FY1997- } \\
\text { FY2006 }\end{array}$ \\
\hline OPERATING EXPENSE & 14,400 & 43,651 & Wifkw, 809 & 1,293 & 3,673 & 3,738 & 2,759 & 540 & . & $=$ & 71,863 \\
\hline & & & 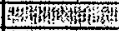 & & & & & & & & \\
\hline CENRTC & - & - & 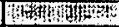 & - & - & - & - & $=$ & - & - & - \\
\hline & & & 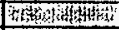 & & & & & & & & \\
\hline GENERAL PLANT PROJECT & - & - & 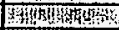 & - & - & - & $=$ & - & - & - & - \\
\hline & & & 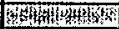 & & & & & & & & \\
\hline LINE ITEM (Llse Each OnO) & & & 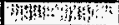 & & & & & & & & \\
\hline 0 & $\cdot$ & $=$ & 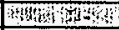 & - & - & - & - & - & - & $=$ & - \\
\hline 0 & - & - & 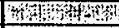 & - & - & - & - & $=$ & $=$ & - & - \\
\hline 0 & $=$ & - & 流 & 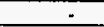 & $=$ & - & - & - & . & - & - \\
\hline of & - & - & 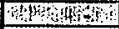 & - & - & - & - & - & - & $=$ & $=$ \\
\hline of & - & - & 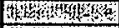 & - & - & - & - & $\because$ & - & - & - \\
\hline of & - & - & 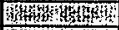 & - & - & - & $=$ & - & - & - & - \\
\hline Subtotal Line Items & - & - & Sond & - & - & - & - & - & - & - & - \\
\hline Escalation & $=$ & - & Whtw & 25 & 149 & 232 & 232 & 50 & - & - & 688 \\
\hline TOTAL BCWSPWO & 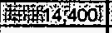 & 43,651 & $\quad 809$ & 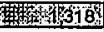 & 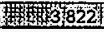 & 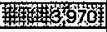 & 12.993 & $-\quad 50 \mathrm{a}$ & 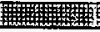 & 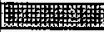 & 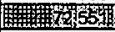 \\
\hline & & & 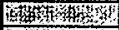 & & & & & & & 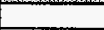 & \\
\hline MGMT RESERVE ${ }^{2}$ & - & - & 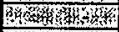 & $\therefore$ & - & - & - & $=$ & - & - & - \\
\hline & & & thesy & & & & & & & & \\
\hline LINE ITEM CONTINGENCY ${ }^{2}$ & $\dot{-}$ & 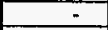 & 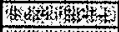 & - & 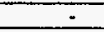 & $\therefore$ & - & - & $\because$ & - & - \\
\hline & & & 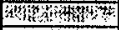 & & & & & & & & \\
\hline TRANSFERS $^{3}$ & - & 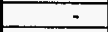 & 13का 98 & 98 & 98 & 98 & 98 & 98 & $=$ & - & 588 \\
\hline & & & Wustowo & & & & & & & & \\
\hline Subtotal & - & $=$ & $2+40,98$ & 98 & 98 & 98 & 98 & 98 &. & - & 588 \\
\hline Escalation & 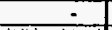 & - & 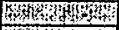 & 2 & 4 & 7 & 9 & 11 & $=$ & - & 33 \\
\hline 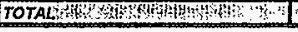 & 14,400 & $4,43,651$ & $3 x^{3} 41_{1}^{1}, 907$ & 1448 & $3 x, 4,924$ & 4,075 & 4, 3,098 & 4699 & HFi & fats & 172 \\
\hline
\end{tabular}

'Budgeled Cost of Work Schodulod (BCWS) Equals Performance Measurement Baseline (PMB); Expense Carryover is Not included

${ }^{2}$ Management Reserve and Line liem Contingency Held by RL

FundsWorkscope Transferred to Other Sites, Transferred to Hanford from Other Sites, and/or FundsWorkscope Controlled by RL. 
ADVANCED REACTORS TRANSITION

LIFE CYCLE COST BASELINE (BCWS) BY YEAR BY FUND TYPE

BY PROJECT BASELINE SUMMARY (PBS)

FY 1999

\begin{tabular}{|c|c|c|c|c|c|c|c|c|c|c|c|c|c|}
\hline $\begin{array}{r}\text { PROJECT WBS: } \\
\text { PBS NO: }\end{array}$ & $\begin{array}{r}1.12 .1 \\
\text { RL-TP11 } \\
\end{array}$ & & & & & $\$ 000$ s) & & & & & & & \\
\hline PBS TITLE: & ADVANCED & EACTORS T & ANSITION & & & & & & & & & & TOTAL \\
\hline FUND TYPE & FY2007 & FY2008 & FY2009 & FY2010 & $\begin{array}{l}\text { FY2011- } \\
\text { FY2015 } \\
\end{array}$ & $\begin{array}{l}\text { FY2016- } \\
\text { FY2020 }\end{array}$ & $\begin{array}{l}\text { FY2021- } \\
\text { FY2025 }\end{array}$ & $\begin{array}{l}\text { FY2026. } \\
\text { FY2030 }\end{array}$ & $\begin{array}{l}\text { FY2031- } \\
\text { FY2036 }\end{array}$ & $\begin{array}{l}\text { FY2036 } \\
\text { FY2040 }\end{array}$ & $\begin{array}{l}\text { FY2041: } \\
\text { FY2045 }\end{array}$ & $\begin{array}{l}\text { FY2046 } \\
\text { FY2050 }\end{array}$ & $\begin{array}{l}\text { FY1997. } \\
\text { FY2050 }\end{array}$ \\
\hline OPERATING EXPENSE & $=$ & 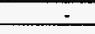 & $\therefore$ & - & - & - & & $=$ & - & 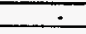 & $\because$ & $\cdot$ & 71,863 \\
\hline & & & & & & & & & & & & & \\
\hline CENRTC & $\therefore$ & - & - & - & - & - & - & - & - & - & - & - & - \\
\hline GENERAL PLANT PRONECT & & & & & 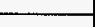 & & & & & & & & \\
\hline & & & 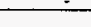 & & $\therefore$ & $\therefore$ & $\therefore$ & - & - & - & - & - & - \\
\hline LINE ITEM (Ust Esch Oms & & & & & & & & & & & & & \\
\hline 0 & 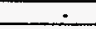 & - & $\div$ & $\overline{-}$ & $\div$ & - & - & - & - & - & - & - & - \\
\hline 0 & - & 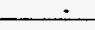 & - & - & - & - & - & - & 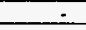 & - & - & - & - \\
\hline 0 & - & - & - & - & - & - & - & $\therefore$ & - & $\therefore$ & - & - & - \\
\hline of & - & - & - & - & - & $=$ & - & - & $=$ & - & - & - & - \\
\hline 0 & $\div$ & - & . & - & - & - & - & $\therefore$ & - & - & - & - & - \\
\hline of & - & $\dot{-}$ & - & - & $\therefore$ & $\therefore$ & $\therefore$ & - & $=$ & - & - & - & $\dot{-}$ \\
\hline Subrotal Une flems & $\therefore$ & - & - & - & - & - & 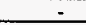 & 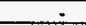 & - & 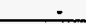 & - & - & - \\
\hline Escalation & $-\bar{x}$ & 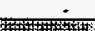 & $-\overline{1}$ & $\therefore$ & m & 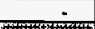 & $\therefore$ & - & $\dot{\sim}$ & - & - & - & 688 \\
\hline TOTALBCW SPMB & 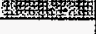 & - & 1 & (19-1) & 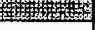 & 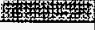 & 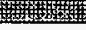 & 櫵 & 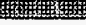 & & 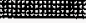 & & 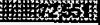 \\
\hline MGMT RESERVE ${ }^{2}$ & - & - & - & - & - & - & $\cdot$ & - & . & - & 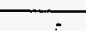 & - & - \\
\hline & & & & & & & & & & & & & \\
\hline LINE ITEM CONTINGENCY & - & $=$ & - & - & - & - & - & $\dot{-}$ & $\dot{-}$ & - & - & - & - \\
\hline TRANSFERS $^{3}$ & - & - & 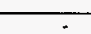 & - & - & - & - & $\cdot$ & - & - & - & & 50 \\
\hline & & & & & & & & & & & & & \\
\hline Subtoral & $=$ & - & - & - & $\div$ & - & - & - & - & - & - & - & 588 \\
\hline Escaiation & $\cdot \dot{0}$ & - & 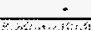 & - & - & - & $\div$ & 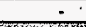 & $\div$ & 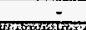 & 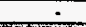 & 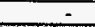 & 33 \\
\hline 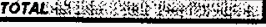 & 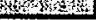 & W & 20 & 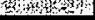 & diston & W & 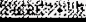 & 38 & 这证理 & 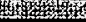 & & & 6 \\
\hline
\end{tabular}

${ }^{1}$ Budgeted Cost of Work Scheduled (BCWS) Equals Performance Measurement Baseline (PMB); Expense Canyover is Not Included

${ }^{2}$ Management Reserve and Line Item Contingency Held by RL

${ }^{3}$ Funds $W$ orkscope Transferred to Other Sites, Transterred to Hanford from Other Sites, andior Funds Workscope Controlled by RL. 


\section{ADVANCED REACTORS TRANSITION}

BUDGET AUTHORITY (B/A) BY YEAR BY FUND TYPE BY PROJECT BASELINE SUMMARY (PBS)

FY 1999

(\$000s)

\begin{tabular}{|c|c|c|}
\hline PROJECT WBS: & \multirow{2}{*}{\multicolumn{2}{|c|}{\begin{tabular}{|r|}
1.12 .1 \\
RL-TP11 \\
\end{tabular}}} \\
\hline PBSNO: & & \\
\hline \multirow[t]{2}{*}{ PBS TITLE: } & ORS TRANSITION & \\
\hline & \multirow{2}{*}{$\begin{array}{l}\text { TARGET } \\
\text { B/A } \\
\text { FY1998 } \\
\end{array}$} & \multirow{2}{*}{ 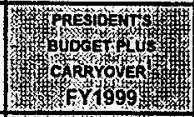 } \\
\hline FUND TYPE & & \\
\hline \multirow[t]{2}{*}{ OPERATING EXPENSE } & 38,380 & 庥1 \\
\hline & & 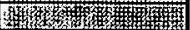 \\
\hline \multirow[t]{2}{*}{ CENRTC } & - & 7 \\
\hline & & 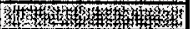 \\
\hline \multirow[t]{2}{*}{ GENERAL PLANT PROJECT } & - & 5 \\
\hline & & 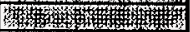 \\
\hline LINE ITEM (Ust Each One) & & rifin \\
\hline 0 & - & 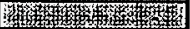 \\
\hline 10 & - & 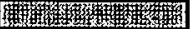 \\
\hline 0 & - & (1) \\
\hline 0 & - & 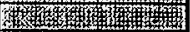 \\
\hline 0 & - & W \\
\hline 0 & - & 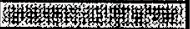 \\
\hline \multirow[t]{2}{*}{ Subtotal Line Items } & - & 䇣绕 \\
\hline & & 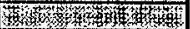 \\
\hline \multirow[t]{2}{*}{ TOTAL NEW B/A : } & 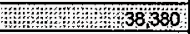 & 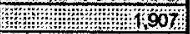 \\
\hline & & 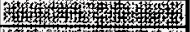 \\
\hline \multirow[t]{2}{*}{ ESTIMATED FY 1998 CARRYOVER } & & 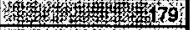 \\
\hline & & $\frac{1}{6}$ \\
\hline TOTALENEW B/A+CARRYOVER & $=61+4,438,380$ & 130,086 \\
\hline
\end{tabular}

'Estimated Carryover is NOT Included In Cost Baseline; Change Request For Actual Carryover Submitted After September 30, 1998. 


\section{B.2 FFTF Project (RL-MS01)}

\section{B.2.1.0 FFTF Project Technical Baseline}

This section describes the technical baseline for this project. It identifies the mission, the end point targets, the site major facilities, technical logic, functions, requirements, and forecasts for this project.

\section{B.2.1.1 FFTF Project Mission}

The FFTF and affiliated 400 Area buildings are to be maintained in a safe and compliant standby condition. The condition of the plant hardware, software and personnel is to be preserved in a manner not to preclude a plant restart.

The Fast Flux Test Facility (FFTF) is the largest, most modern, liquid metal-cooled test reactor in the world. Originaliy constructed in the late 1970s, it's purpose was to support the U.S. Liquid Metal Fast Breeder Reactor (LMFBR) Program. The FFTF began power operation in 1982 and demonstrated its ability to perform fuel and materials tests in support of both national and international fast breeder reactor programs, produce medical and industrial isotopes, perform materials tests for the fusion and space programs, perform passive safely tests, and provide customized neutron environments to meet customer needs. Detailed studies were also done to show the feasibility of producing significant quantities of Plutonium-238, as well as approximately 100 megawatts of electrical power with the addition of a steam powered turbine generator.

In January 1990, after a U. S. Department of Energy (DOE) evaluation of potential long term missions for the FFTF, DOE concluded that justification to support the expense of continued operation did not exist. This lead to a series of new studies and marketing efforts by the Governor of the State of Washington, in cooperation with the Congressional Delegation of the State. Eventually the Secretary of Energy informed the Washington State Congressional Delegation that DOE planned to commence a phased shutdown process on December 15, 1993, to place the FFTF in a radiologically and industrially safe shutdown condition. Accordingly, removal of the fuel from the reactor vessel began in March 1994 and was completed in April 1995. Following this major accomplishment, the washing of sodium wetted, fueled components was successfully demonstrated.

In order to remove the spent nuclear fuel from storage in the FFTF, procurement contracts were placed for the fabrication of Interim Storage Casks (ISC) and Core Component Containers (CCC) that will be used for the dry storage of washed, FFTF nuclear fueled components. The CCC, when filled with up to seven clean FFTF fueled components, is placed inside of an ISC and transported to the 400 Area Interim Storage Area (ISA), located in the northeast comer of the FFTF complex. The 400 Area ISA is large enough to also store spent nuclear fuel from other facilities in the Hanford 300 Area.

After preparations were made to support the early draining of the secondary loop sodium to in-plant storage tanks in November 1995, DOE ordered all drain activities delayed while an expedited review was conducted on the possible benefits of continued reactor operation for tritium production. Eventually, DOE suspended actions to drain the secondary loop sodium until further notice and deferred all activities that would affect the potential to restart the reactor. Then in January 1997, the Secretary of Energy, by Memorandum of Decision (MOD), directed the FFTF be maintained in a standby condition while studies are conducted to determine if the FFTF can perform a role in augmenting the current, dual-track tritum production options. By December 1998 the DOE is to determine the primary, long-term source of tritium and any potential augmentation role for the FFTF. The MOD identifies two options for producing tritium - building an accelerator or converting a commercial reactor - with the FFTF considered as either a backup or a stopgap measure. Despite these delays to the shutdown plan, significant progress has been 
made in several key areas which include: packaging and storing highly-radioactive, spent, fueled components in ISCs; procedure preparation for draining plant sodium; completing the reactor vessel plenum drill development project; and completing the construction of the Sodium Storage Facility (SSF). The new SSF is located adjacent to the FFTF and is capable of storing 292,000 gallons of radioactive sodium, which will accommodate all drainable sodium from the FFTF.

The FMEF was built during the late 1970 s and early 1980 s as a major addition to the breeder reactor technology development program. Its design was initiated in 1978 and underwent several major changes in scope as a result of changes in the direction of the DOE's breeder reactor development programs. The initial design concept was to provide a facility with capability to destructively and nondestructively inspect irradiated fuel materials from the DOE Research and Development Breeder Reactor projects being developed at that time (the FFTF and the Clinch River Breeder Reactor Plant [CRBRP]). The first facility scope revision occurred in April 1979, when a second breeder reactor development facility was incorporated within the FMEF design. This facility, the High Performance Fuels Laboratory (HPFL), was to produce breeder reactor fuel assemblies for the FFTF and the CRBRP. It included fabrication of high-exposure and spiked fuels for proliferation resistance. During 1979, the U.S. Government's proliferation policy was changed and the need for a HPFL type of fuel fabrication was eliminated. As a result, the HPFL process was replaced by the Secure Automated Fabrication (SAF) Line in October 1980. Further changes in the DOE Breeder Reactor Program direction resulted in a facility scope reduction in October 1983, removing the irradiated fuel examination functions. During 1983, modifications to the shops and storage portion of the Entry Wing were incorporated for FFTF fuel assembly fabrication (pins to assemblies). The Fuel Assembly Area (FAA) was then established and configured to support fuel pin inspection, assembly, and storage. Low-exposure, SAF-fabricated driver fuel pins would be transferred to the FAA for final processing. With the demise of the DOE Breeder Reactor Program, the SAF Project was canceled. Several other projects have altered the original design of the facility, but none have ever come to fruition. The facility will be closed, in standby, except for limited use of shop and storage space for activities in support of the Spent Nuclear Fuels Project and the Tank Waste Remediation Project.

\section{B.2.1.2 FFTF Project End Point Targets from Hanford Strategic Plan}

- Spent fuels (TRIGA and light water reactor) and applicable FFTF fuels removed from 400 Area interim storage area to 200 Area.

- Transition high cost surplus facilities to a low cost, stable, deactivated condition.

- Transition the FFTF to low cost, stable, deactivated condition.

- Reuse facilities in the south 600 area for economic diversification where feasible.

\section{B.2.1.3 FFTF Project Major Facilities}

\section{B.21.3.1 FFTF Facility}

\section{B.2.1.3.1.1 FFTF Facility Description}

FFTF consists of a fast flux test reactor and numerous support facilities. The reactor uses plutonium-uranium oxide fuel and sodium coolant. It has a power rating of $400 \mathrm{MW}$. Service and auxiliary buildings and facifities are provided for control of the plant, receiving and shipping of fuel and equipment, storage of irradiated fuel, secondary coolant system equipment, service systems, equipment decontamination and repair, and other operating and administrative services. 


\section{B.2.1.3.1.2 FFTF Facility Technical Logic:}

The Department of Energy (DOE), in partnership with its contractors, shall plan, acquire, operate, maintain, and dispose of physical assets as valuable national resources. Stewardship of these physical assets shall be accomplished in a cost-effective manner to meet the DOE mission. This shall incorporate industry standards, a graded approach, and performance objectives.

This diagram displays the primary work activities (functions) that are performed in eact life cycle phase of the facility. The diagram also reflects the technical logic (functional flow) for the facility through its remaining life cycle phases.

Project responsibility for the life cycle phases of the FFTF components are assigned as follows:

Table B.2-1 Responsibility Assignment Matrix for FFTF

\begin{tabular}{|c|c|c|c|c|c|c|c|c|c|}
\hline \multirow{3}{*}{ Facility } & \multicolumn{9}{|c|}{ Life Cycle Phase * } \\
\hline & \multirow{2}{*}{$\begin{array}{l}\text { Program } \\
\text { Planning }\end{array}$} & \multirow{2}{*}{$\begin{array}{c}\text { Pre } \\
\text { Conceptual }\end{array}$} & \multirow[b]{2}{*}{ Conceptual } & \multicolumn{3}{|c|}{ Execune } & \multirow[b]{2}{*}{$\mathrm{OgM}$} & \multicolumn{2}{|c|}{ Close Out } \\
\hline & & & & Design & Construction & Tumover & & Post Ops & D\&D \\
\hline FFTF & RL-MSOT & & & & & & RL-MSOT & $\begin{array}{l}\text { RL-MS01 } \\
\text { RL-ER05 }\end{array}$ & $\begin{array}{l}\text { RL-ER06 } \\
\text { RL-ER07 }\end{array}$ \\
\hline
\end{tabular}

- RL PBS Identifier index:

RL-MS01 - FFTF Project

RL-ER05 - Surveillance and Maintenance

RL-ER06 - Decontamination \& Decommissioning

RL-ER07 - Long Term Surveillance and Maintenance 
HNF-SP-1240

Rev: 1

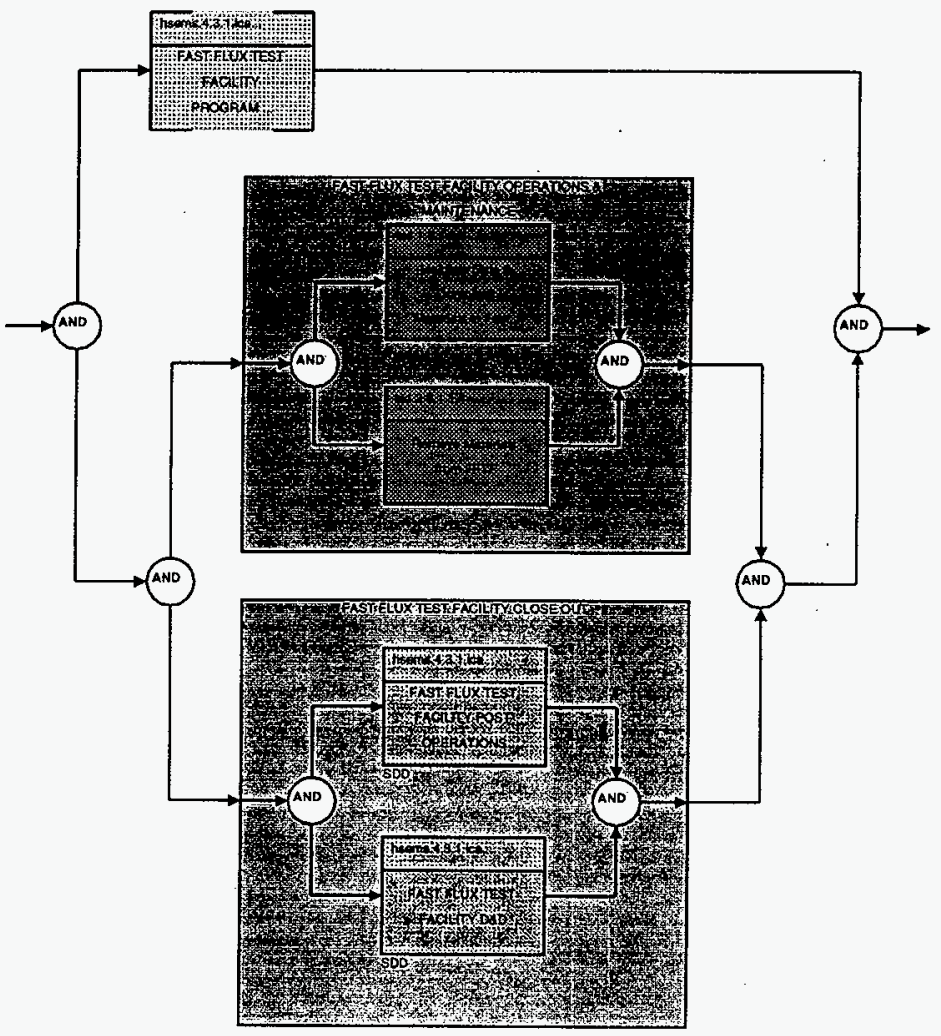

Figure B.2_1 FAST FLUX TEST FACILITY 


\section{B.21.3.1.3 FFTF Life Cycle Functional Descriptions and Requirements}

The Life Cycle Functional Descriptions table describes the life cycle phases and the functions performed during each piase. The Life Cycle Requirements table describes the requirements that trace to the functions listed in the Life Cycle Functional Descriptions table.

Table B.2-2 FFTF Life Cycle Functional Descriptions

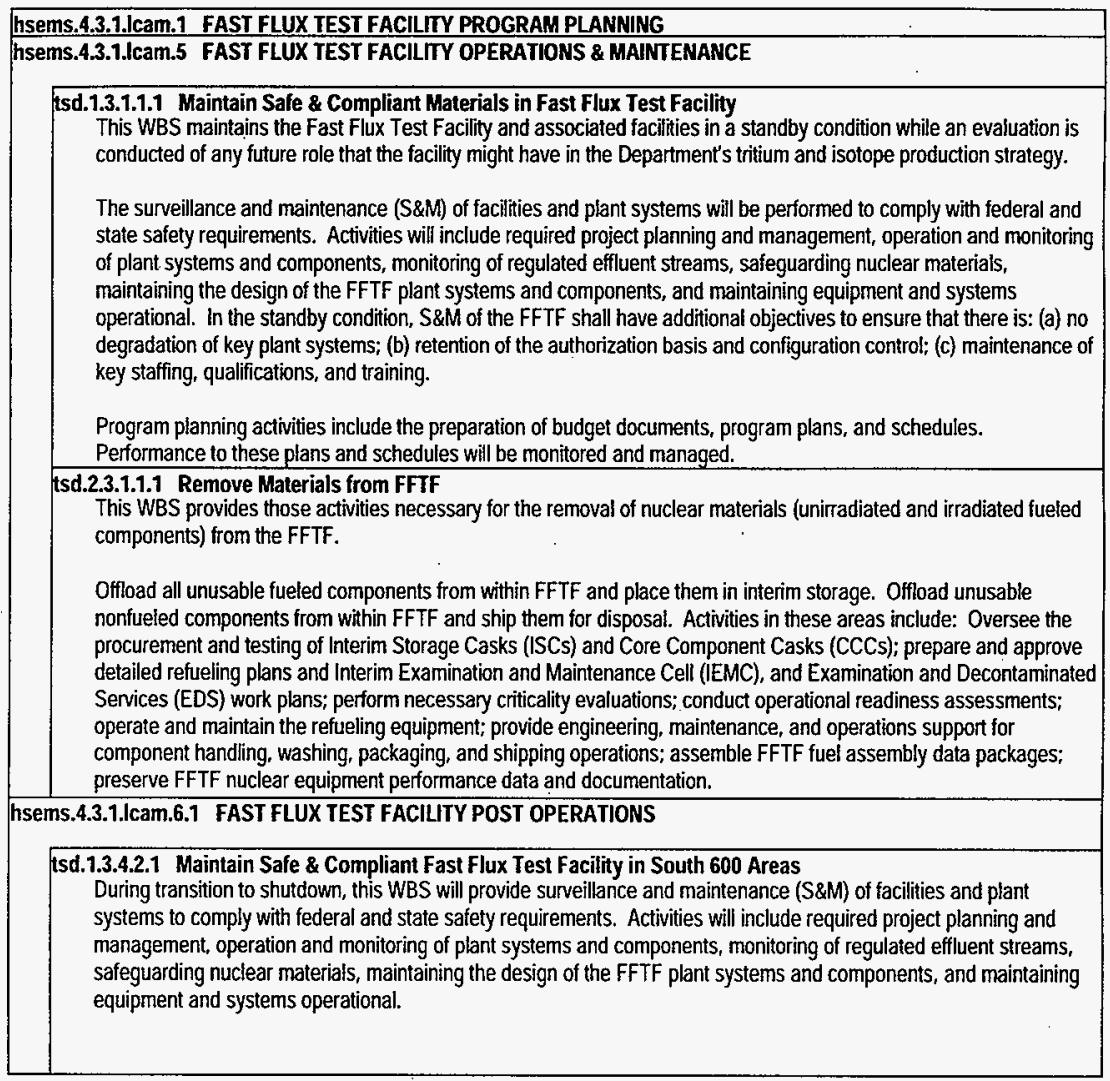




\section{Table B.2-2 FFTF Life Cycle Functional Descriptions (Continued)}

tsd,2.3.4.2.1 Transition the Fast Flux Test Facility

This WBS will accomplish those activities which move the FFTF to an industrially and radiologically safe shutdown condition, once DOE has determined that the FFTF is no longer required for any future mission.

Activities will include removing unusable spent nuclear fuel components from the FFTF to dry cask storage. Irradiated, non-fueled components will also be removed from the FFTF and dispositioned for proper disposal. Any remaining. unirradiated fuel components will be removed for proper disposition. The fuel handling equipment will be maintained and upgraded, where appropriate, to ensure reliability.

Sodium and NaK systems will be drained, to the extent practical, to the tanks in the Sodium Storage Facility. Residual sodium will be protected under a blanket of non-reactive gas.

Reactor plant systems will be placed in a safe condition for long-term surveillance and maintenance pending final deactivation and decommissioning.

\section{Table B.2-3 FFTF Life Cycle Requirements}

\begin{tabular}{|c|c|}
\hline Requirement & Function \\
\hline $\begin{array}{l}\text { The stabilizing and reconfiguring facilities for minimum S\&M including deactivation of non-essential utilities, } \\
\text { process systems, and other facility systems; modification of facility safety, ventilation, monitoring, electrical, and } \\
\text { utility systems; removal of resources and waste; and transfer of the facility to the ERC. Remaining active systems } \\
\text { shall be capable of operation and statusing from a location outside the facility so only quarterly personnel entry is } \\
\text { required. Facility electrical systems shall be reconfigured so only minimal portions can be operated as required to } \\
\text { support personnel entry. All facility reconfiguration shall be performed under Occupational Safety and Health } \\
\text { Administration construction requirements. }\end{array}$ & $\operatorname{tsd}$.2.3.4.2.1 \\
\hline $\begin{array}{l}\text { ispositioning facility inventories of SNWNMNF through the stabilization, treatment, packaging, temporary } \\
\text { orage, documentation preparation, and transportation of these materials to another locations. }\end{array}$ & tsd.2.3.4.2.1 \\
\hline Ensuring final facility configurations do not preclude D\&D activities. & tsd.2.3.4.2.1 \\
\hline $\begin{array}{l}\text { Managing SNMNMNF material as follows: } \\
\text { Consolidating SNMNMNN materials early in the facility deactivation process to minimize the safety and } \\
\text { compliance envelope. Where feasible, these materials shall be removed from the facility early in the deactivation } \\
\text { process. When deactivation is complete, a facility shall no longer contain SNM/NWNF. } \\
\text { Safely and compliantly storing SNMNM/NF until a national policy on disposition is formulated. The } \\
\text { SNM/NMNF shall be transferred to other beneficial uses where possible. All NM held by DOE contractors shall } \\
\text { be stored, transferred, and dispositioned in compliance with DOE gutdance and federal, state, and local laws. } \\
\text { Continuing the current SNM/NWNF safety and security approach, with necessary interim upgrades, until a } \\
\text { preferred longer term approach is selected. } \\
\text { Continuing development and implementation of criteria for the receipt, storage, treatment, and disposition of } \\
\text { SNM/NM/NF. } \\
\text { Continuing studies to determine the best alternatives for onsite material storage } \\
\text { Actively involving stakeholders in the development of long-term treatment, storage, and disposition plans } \\
\text { through the NEPA process. } \\
\text { Delaying SNMNM/NF treatment for ultimate disposition until final disposition for these materials is } \\
\text { determined. }\end{array}$ & tsd.2.3.4.2.1 \\
\hline High cost surplus facilties and systems shall be transitioned to a low cost, sta & tsd.2.3.4.2.1 \\
\hline Facilities and systems shall be made available for other uses. & tsd.2.3.4.2.1 \\
\hline 400 Area surplus facilties shall be transitioned to the surveillance and maint & tsd.2.3.4.2.1 \\
\hline FFTF shall be transitioned to the surveillance and maintenance phase & tsd.2.3.4.2.1 \\
\hline South 600 Area special nuclear materials shall be moved to the Central Plateau & tsd.2.3.1.1.1 \\
\hline be moved from the 400 Area to the Centre & tsd.2.3.1.1.1 \\
\hline $\begin{array}{l}\text { South } 600 \text { Area gaseous effluent releases sho } \\
\text { FFTF shall be maintained within the apnroved }\end{array}$ & tsd.1.3.4.2.1 \\
\hline FFTF shall be $m$ & tssd.1.3.4.2.1 \\
\hline
\end{tabular}


Table B.2-3 FFTF Life Cycle Requirements (Continued)

\begin{tabular}{|c|c|}
\hline Requirement & Function \\
\hline $\begin{array}{l}\text { Spent fuels (light water reactor) shall be moved from the } 400 \text { Area interim storage to the Central Plateau Interim } \\
\text { Storaqe }\end{array}$ & tsd.1.3.1.1.1 \\
\hline 400 Area Nuclear materials shall be stabilized & tsd.2.3.1.1.1 \\
\hline Complete transfer of irraditated fuel to dry cask storage. Due Date: 10/31/1998 & tsd.2.3.4.2.1 \\
\hline Complete transfer of unirraditated fuel to the Plutonium Finishing Plant. Due Date: $10 / 31 / 1998$ & $\operatorname{tsd} .2 .3 .4 .2 .1$ \\
\hline $\begin{array}{l}\text { Complete transfer of special fuel to the Idaho National Engineering Laboratory for consolidated storage. Due } \\
\text { Date: } 10 / 31 / 1998\end{array}$ & tsd.2.3.4.2.1 \\
\hline Complete auxiliary systems deactivation. Due Date: $3 / 31 / 2001$ & Isd.2.3.4.2.1 \\
\hline Complete Sodium storage facility startup. Due Date: $7 / 31 / 1998$ & tsd.2.3.4.2.1 \\
\hline Complete FFTF Sodium drain. Due Date: 3/31/2000 & tsd.2.3.4.2.1 \\
\hline Complete PCB transformer disposal. Due Date:9/30/2001 & tsd.2.3.4.2.1 \\
\hline $\begin{array}{l}\text { Complete commercial disposition and/or the acquisition of new facilities, modification of existing facilities, and/or } \\
\text { modification of planned facilities necessary for storage, treatment/processing, and disposaldisposition of all } \\
\text { Hanford Site UU. }\end{array}$ & $\begin{array}{l}\text { tsd.2.3.1.1.1 } \\
\text { tsd.2.3.4.2.1 } \\
\text { hsems.4.3.1. } \\
\text { cam.6.1 }\end{array}$ \\
\hline $\begin{array}{l}\text { This target date includes all UU located in } 300 \text { Area fuel supply facilities (Uranium dioxide powder and pellets } \\
\text { stored in cans, pins, assemblies, and drums), Uranium trioxide (UO3) powder stored in T-hoppers adjacent to the } \\
\text { U-Plant, depleted UO3 stored in } 55 \text { gallon drums in the } 200 \text { West Area and the } 4713 \text { Building. }\end{array}$ & \\
\hline Due Date: $12 / 31 / 2000$ & \\
\hline $\begin{array}{l}\text { The Contractor shall manage the stabilization/disposition of nuclear material, fuel, and hazardous materials, and } \\
\text { the deactivation of the FFTF and associated systems to a condition ready for final disposition, reducing the risk } \\
\text { and attain the lowest surveillance and maintenance cost. The Contractor shall complete the sodium removal, } \\
\text { wash the fuel elements, and place the cleaned elements in dry casks for storage. The Contractor shall complete } \\
\text { the deactivation of FFTF. }\end{array}$ & tsd.2.3.4.2.1 \\
\hline
\end{tabular}

\section{B.2.1.3.1.4 FFTF Boundary Diagram}

This section identifies the other facilities (onsite and offsite) that have an interface (either input or output) with this facility.

Table B.2-4 FFTF Boundary Diagram

\begin{tabular}{|l|l|l|}
\hline \multicolumn{1}{|c|}{ Major Input lnterfaces } & \multicolumn{1}{|c|}{ Facility } & \multicolumn{1}{|c|}{ Major Oufput loterfaces } \\
\hline External Interfaces & FFTF & External Interfaces \\
Hanford Legacy & & Hazardous Waste Disposal Contracts \\
Offsite Landfit \\
Hanford Site Environmental System Interfaces & & Hantord Site Environmental System Interfaces \\
$3717 B$ & & 200 Interim Storage Area (ISA) \\
CP General Purpose Shop & & $222-S$ Laboratory \\
Misc Rad Labs & & $242 A$ \\
S600 Electrical Distribution & & Double Shell Tank (DST) System \\
S600 General Purpose Office & & PFP \\
S600 General Purpose Shop & & \\
S600 General Purpose Warehouse & & \\
S600 Telecommunications System & & \\
\hline
\end{tabular}

\section{B.2.1.3.1.5 FFTF Interface Descriptions and Summary Level Forecasts}

This section contains the material, waste, and infrastructure forecasts for this facility. It identifies the interface type, the period of time for the forecasts, the life cycle total forecast value, and the execution year forecast quantity.

\section{OFFSITE INPUTS}


Table B.2-5 Offsite Inputs for FFTF

\begin{tabular}{|c|c|c|c|c|c|}
\hline Stream & Category & Period & Total & FY99 & Units \\
\hline \multicolumn{6}{|l|}{ X.0 Hanfoxd Legacy } \\
\hline Initial FFTF Highly Enriched Uranium & $\begin{array}{l}\text { Highly Enriched Uranium } \\
\text { (HEU) }\end{array}$ & $1999-1999$ & 42.7 & 42.7 & kilograms \\
\hline $\begin{array}{l}\text { Initial FFTF LLW (Liquid) } \\
\text { Initial FFTF Depleted Uranium } \\
\text { Initial FFTF Natural Uranium } \\
\text { Initial FFTF Phtoniltim } \\
\text { Initial FFTF Spent Nuclear Fued }\end{array}$ & $\begin{array}{c}\text { LLW (Liquid) } \\
\text { Depleted Uranium (DU) } \\
\text { Natural Uranium (NU) } \\
\text { Plutonium (Pu) } \\
\text { Spent Nuclear Fuel (SNF) }\end{array}$ & $\begin{array}{r}1999-1999 \\
1999-1999 \\
1999-1999 \\
1999-1999 \\
1999-1999 \\
\end{array}$ & $\begin{array}{c}39.0 \\
338.0 \\
0.0 \\
285.0 \\
11.1\end{array}$ & $\begin{array}{c}39.0 \\
338.0 \\
0.0 \\
285.0 \\
11.1 \\
\end{array}$ & $\begin{array}{l}\text { cubic meters } \\
\text { kilograms } \\
\text { kilograms } \\
\text { kilograms } \\
\text { MTHM }\end{array}$ \\
\hline
\end{tabular}

\section{ONSITE INPUTS}

Table B.2-6 Onsite Inputs for FFTF

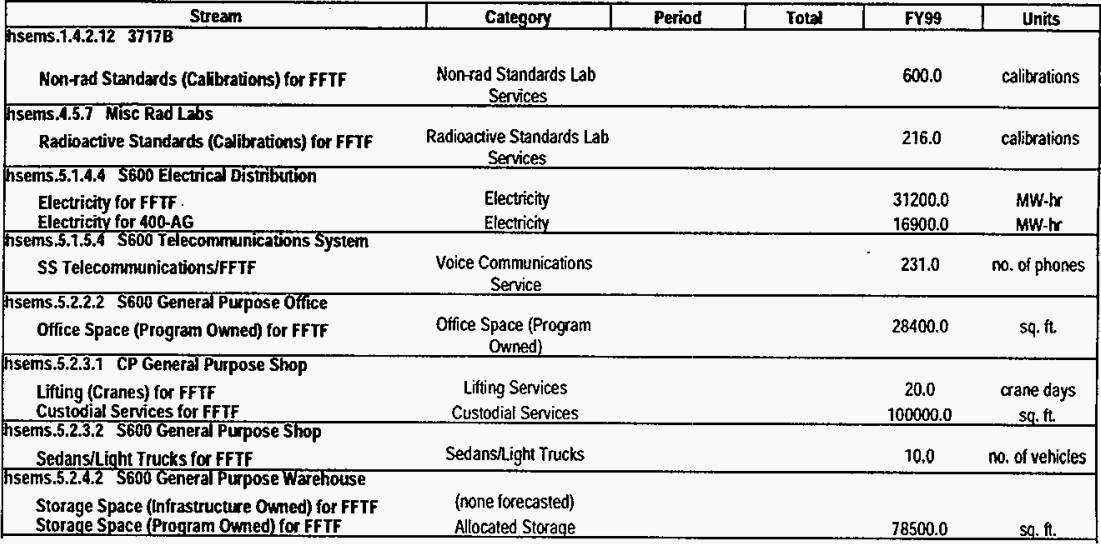

\section{OFFSITE OUTPUTS}

Table B.2-7 Offsite Outputs for FFTF

\begin{tabular}{|c|c|c|c|c|c|}
\hline Stream & Category & Period & Tota! & FY99 & Units \\
\hline \multicolumn{6}{|c|}{ X Hazardous Waste Disposa Contracts } \\
\hline FFTF Asbestos & Asbestos & $1999-2001$ & $\$ 4.0$ & 4.0 & cubic meters \\
\hline FFTF Hazardous Waste & HAZ & $1999-2002$ & 7.47 & 1.73 & cubic meters \\
\hline $\begin{array}{l}X \text { Ofisite Landfill } \\
\text { FFIF Sanitary Solid Waste }\end{array}$ & Sanitary Solid Waste & $1999-2001$ & 11200 & 3730.0 & cubic meters \\
\hline
\end{tabular}

\section{ONSITE OUTPUTS}

Table B.2-8 Onsite Outputs for FFTF

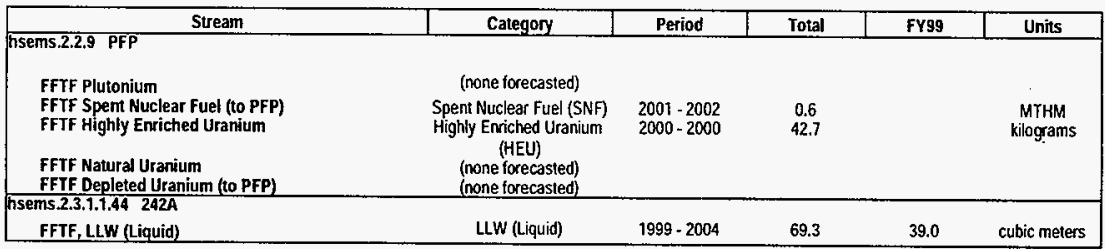


HNF-SP-1240

Rev: 1

Table B.2-8 Onsite Outputs for FFTF (Continued)

\begin{tabular}{|c|c|c|c|c|c|}
\hline Stream & Category & Period & Total & FY99 & Units \\
\hline $\begin{array}{l}\text { 15ems.2.3.1.2 Double Shell Tank (DST) System } \\
\text { FFTF, HLW }\end{array}$ & $\mathrm{HLW}$ & $1999-2015$ & 0.0 & 0.0 & cubic meters \\
\hline $\begin{array}{l}\text { hsems.2.3.4 } 200 \text { Interim Storage Area (ISA) } \\
\text { SNF Removed from FFIF }\end{array}$ & Spent Nuclear Fuel (SNF) & $2000 \cdot 2003$ & 10.2 & & MTHM \\
\hline $\begin{array}{l}\text { Ansems.2.5.1 222-\$ Laboratory } \\
\text { Antical Laboratory Services for FFTF }\end{array}$ & $\begin{array}{l}\text { Analytical Laboratory } \\
\text { Services }\end{array}$ & & & 20.0 & samples \\
\hline
\end{tabular}

\section{B.21.4 Drivers for FFTF Project}

Table B.2-9 Source Documents for FFTF Project

Name

DE-AC06-96RL13200

DOE/EIS-0222D

DOE/RL-89-10

DOE/RL-96-92

DOE/RL-97-55
Title

Project Hanford Management Contract, Fluor Daniel Hanford, inc.

Draft Hanford Remedial Action Environmental Impact Statement and Comprehensive Land Use Plan

Hanford Federal Facility Agreement and Consent Order (Tri-Party Agreement), Rev.4

Hanford Strategic Plan

Hanford Site Environmental Management Specification 
B.22.0 FFTF Project Work Breakdown Structure (WBS)

B.2.2.1 FFTF Project WBS Hierarchy

\begin{tabular}{lll}
\hline RL PBS & RL WBS & Title \\
\hline RL-MS01 & 2.01 .01 .01 .21 .01 & FFTF Project \\
& 2.01 .01 .01 .21 .01 .01 & FFTF \\
& 2.01 .01 .01 .21 .01 .01 .01 & Maintain Safe \& Compliant Materials in Fast Flux Test Facility \\
& 2.01 .01 .01 .21 .01 .01 .02 & Remove Materials from FFTF \\
& 2.01 .01 .01 .21 .01 .01 .03 & Maintain Safe \& Compliant Fast Flux Test Facility in South 600 Areas \\
& 2.01 .01 .01 .21 .01 .01 .04 & Transition the Fast Flux Test Facility \\
\hline
\end{tabular}

B.2.2.2 FFTF Project WBS Dictionary

The following pages contain the WBS dictionary for RL-MS01 
1. Dictionary Title

2. Date

Maintain Safe \& Compliant Materials in Fast Flux Test Facility 111 August 1998

5. WBS No.

6. $B \& R$ No.

3. PBS Number 4. Dict Rev

2.01.01.01.21.01.01.01

RL-MS01

8. Organization Name

FFTF Project

9. Scope of Work

This WBS maintains the Fast Flux Test Facility and associated facilities in a standby condition while an evaluation is conducted of any future role that the facility might have in the Department's tritium and isotope production strategy.

The surveillance and maintenance (S\&M) of facilities and plant systems will be performed to comply with federal and state safety requirements. Activities will include required project planning and management, operation and monitoring of plant systems and components, monitoring of regulated effluent streams, safeguarding nuclear materials, maintaining the design of the FFTF plant systems and components, and maintaining equipment and systems operational. In the standby condition, S\&M of the FFTF shall have additional objectives to ensure that there is: (a) no degradation of key plant systems; (b) retention of the authorization basis and configuration control; (c) maintenance of key staffing, qualifications, and training.

Program planning activities include the preparation of budget documents, program plans, and schedules.

Pefformance to these plans and schedules will be monitored and managed.

This WBS covers work necessary to support satisfying the following technical baseline requirements for the Hanford clean up mission:

- $\quad$ Spent fuels (light water reactor) shall be moved from the 400 Area interim storage to the Central Plateau Interim Storage 
1. Dictionary Title
Remove Materials from FFTF

5. WBS No.

2.01.01.01.21.01.01.02

8. Organization Name

FFTF Project

9. Scope of Work

This WBS provides those activities necessary for the removal of nuclear materials (unirradiated and irradiated fueled components) from the FFTF.

Offload all unusable fueled components from within FFTF and place them in interim storage. Offload unusable nonfueled components from within FFTF and ship them for disposal. Activities in these areas include: Oversee the procurement and testing of Interim Storage Casks (ISCs) and Core Component Casks (CCCs); prepare and approve detailed refueling plans and Interim Examination and Maintenance Cell (IEMC), and Examination and Decontaminated Services (EDS) work plans; perform necessary criticality evaluations; conduct operational readiness assessments; operate and maintain the refueling equipment; provide engineering, maintenance, and operations support for component handling, washing, packaging, and shipping operations; assemble FFTF fuel assembly data packages; preserve FFTF nuclear equipment performance data and documentation.

This WBS covers work necessary to support satisfying the following technical baseline requirements for the Hanford clean up mission:

- South 600 Area special nuclear materials shall be moved to the Central Plateau

- Nuclear materials shall be moved from the 400 Area to the Central Plateau

- $\quad 400$ Area Nuclear materials shall be stabitized

- Complete commercial disposition and/or the acquisition of new facilities, modification of existing facilities, and/or modification of planned facilities necessary for storage, treatment/processing, and disposal/disposition of all Hanford Site UU.

This target date includes all UU located in 300 Area fuel supply facitities (Uranium dioxide powder and pellets stored in cans, pins, assemblies, and drums), Uranium trioxide (UO3) powder stored in T-hoppers adjacent to the U-Plant, depleted UO3 stored in 55 gallon drums in the 200 West Area and the 4713 Building.

Due Date: $12 / 31 / 2000$ 
1. Dictionary Title

2. Date

Maintain Safe \& Compliant Fast Flux Test Facility in South 60011 August 1998

Areas

5. WBS No.

2.01.01.01.21.01.01.03

6. B \& R No.

3. PBS Number 4 . Dict Rev

RL-MS01

8. Organization Name

FFTF Project

9. Scope of Work

During transition to shutdown, this WBS will provide surveillance and maintenance (S\&M) of facilities and plant systems to comply with federal and state safety requirements. Activities will include required project planning and management, operation and monitoring of plant systems and components, monitoring of regulated effluent streams, safeguarding nuclear materials, maintaining the design of the FFTF plant systems and components, and maintaining equipment and systems operational.

This WBS covers work necessary to support satisfying the following technical baseline requirements for the Hanford clean up mission:

South 600 Area gaseous effluent releases shall be monitored

FFTF shall be maintained within the approved safety envelope 


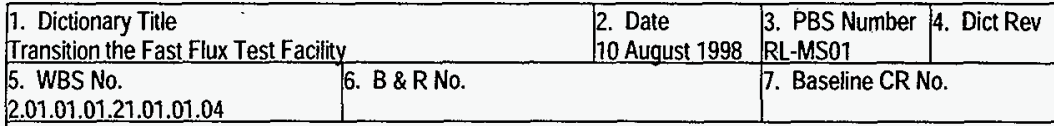

8. Organization Name

FFTF Project

9. Scope of Work

This WBS will accomplish those activities which move the FFTF to an industrially and radiologically safe shutdown condition, once DOE has determined that the FFTF is no longer required for any future mission.

Activities will include removing unusable spent nuclear fuel components from the FFTF to dry cask storage. Irradiated, non-fueled components will also be removed from the FFTF and dispositioned for proper disposal. Any remaining, unirradiated fuel components will be removed for proper disposition. The fuel handling equipment will be maintained and upgraded, where appropriate, to ensure reliability.

Sodium and NaK systems will be drained, to the extent practical, to the tanks in the Sodium Storage Facility. Residual sodium will be protected under a blanket of non-reactive gas.

Reactor plant systems will be placed in a safe condition for long-term surveillance and maintenance pending final deactivation and decommissioning.

This WBS covers work necessary to support satisfying the following technical baseline requirements for the Hanford clean up mission:

- The stabilizing and reconfiguring facilities for minimum S\&M including deactivation of non-essential utilities, process systems, and other facility systems; modification of facility safety, ventilation, monitoring, electrical, and utility systems; removal of resources and waste; and transfer of the facility to the ERC. Remaining active systems shall be capable of operation and statusing from a location outside the facility so only quarterly personnel entry is required. Facility electrical systems shall be reconfigured so only minimal portions can be operated as required to support personnel entry. All facility reconfiguration shall be performed under Occupational Safety and Health Administration construction requirements.

Dispositioning facility inventories of SNM/NM/NF through the stabilization, treatment, packaging, temporary storage, documentation preparation, and transportation of these materials to another locations.

Ensuring final facility configurations do not preclude D\&D activities. 
- Managing SNM/NM/NF material as follows:

- Consolidating SNM/NM/NF materials early in the facility deactivation process to minimize the safely and compliance envelope. Where feasible, these materials shall be removed from the facility early in the deactivation process. When deactivation is complete, a facility shall no longer contain SNM/NM/NF. - Safely and compliantly storing SNM/NM/NF until a national policy on disposition is formulated. The SNM/NM/NF shall be transferred to other beneficial uses where possible. All NM held by DOE contractors shall be stored, transferred, and dispositioned in compliance with DOE guidance and federal, state, and local laws.

- Continuing the current SNM/NM/NF safety and security approach, with necessary interim upgrades, until a preferred longer term approach is selected.

- Continuing development and implementation of criteria for the receipt, storage, treatment, and disposition of SNM/NM/NF.

- Continuing studies to determine the best alternatives for onsite material storage

- Actively involving stakeholders in the development of long-term treatment, storage, and disposition plans through the NEPA process.

- Delaying SNM/NM/NF treatment for ultimate disposition until final disposition for these materials is determined.

High cost surplus facitties and systems shall be transitioned to a low cost, stable, deactivated condition. Facilities and systems shall be made available for other uses.

400 Area surplus facilties shall be transitioned to the surveillance and maintenance phase

FFTF shall be transitioned to the surveillance and maintenance phase

Complete transfer of irraditated fuel to dry cask storage. Due Date: 10/31/1998.

Complete transfer of unirraditated fuel to the Piutonium Finishing Plant. Due Date: 10/31/1998

Complete transfer of special fuel to the Idaho National Engineering Laboratory for consolidated storage.

Due Date: 10/31/1998

Complete auxiliary systems deactivation. Due Date: 3/31/2001

Complete Sodium storage facility startup. Due Date: 7/31/1998

Complete FFTF Sodium drain. Due Date: 3/31/2000

Complete PCB transformer disposal. Due Date:9/30/2001

Complete commercial disposition and/or the acquisition of new facilities, modification of existing facilities, and/or modification of planned facilities necessary for storage, treatment/processing, and disposal/disposition of all Hanford Site UU.

This target date includes all UU located in 300 Area fuel supply facilities (Uranium dioxide powder and pellets stored in cans, pins, assemblies, and drums). Uranium trioxide (UO3) powder stored in T-hoppers adjacent to the U-Plant, depleted UO3 stored in 55 gallon drums in the 200 West Area and the 4713 Building.

\section{Due Date: $12 / 31 / 2000$}

The Contractor shail manage the stabilization/disposition of nuclear material, fuel, and hazardous materials, and the deactivation of the FFTF and associated systems to a condition ready for final disposition, reducing the risk and attain the lowest surveillance and maintenance cost. The Contractor shall complete the sodium removal, wash the fuel elements, and place the cleaned elements in dry casks for storage. The Contractor shall complete the deactivation of FFIF. 
HNF-SP-1240

Rev. 1

\section{B.2.2.3 FFTF Project Responsibility Assignment Matrix}

\begin{tabular}{|l|l|l|}
\hline WBS Number & Title & Responsible Manager \\
\hline 2.01 .01 .01 .21 .01 & FFTF Project & $\begin{array}{l}\text { W. J. Apley, PNNL* } \\
\text { D. B. Klos, FDH* } \\
\text { E. F. Loika, BWHC }\end{array}$ \\
\hline 2.01 .01 .01 .21 .01 .01 & FFTF & E. F. Loika \\
\hline 2.01 .01 .01 .21 .01 .01 .01 & $\begin{array}{l}\text { Maintain Safe \& Compliant Materials } \\
\text { in Fast Flux Test Facility }\end{array}$ & E. F. Loika \\
\hline 2.01 .01 .01 .21 .01 .01 .02 & Remove Materials from FFTF & E. F. Loika \\
\hline 2.01 .01 .01 .21 .01 .02 .03 & $\begin{array}{l}\text { Maintain Safe \& Compliant Fast Flux } \\
\text { Test Facility in South 600 Area }\end{array}$ & E. F. Loika \\
\hline 2.01 .01 .01 .21 .01 .02 .04 & Transition the Fast Flux Test Facility & E. F. Loika \\
\hline
\end{tabular}

*In accordance with Responsibility Accountability Matrix approved by DOE September 11, 1997. (DOE letter number 97-SPO-062) 


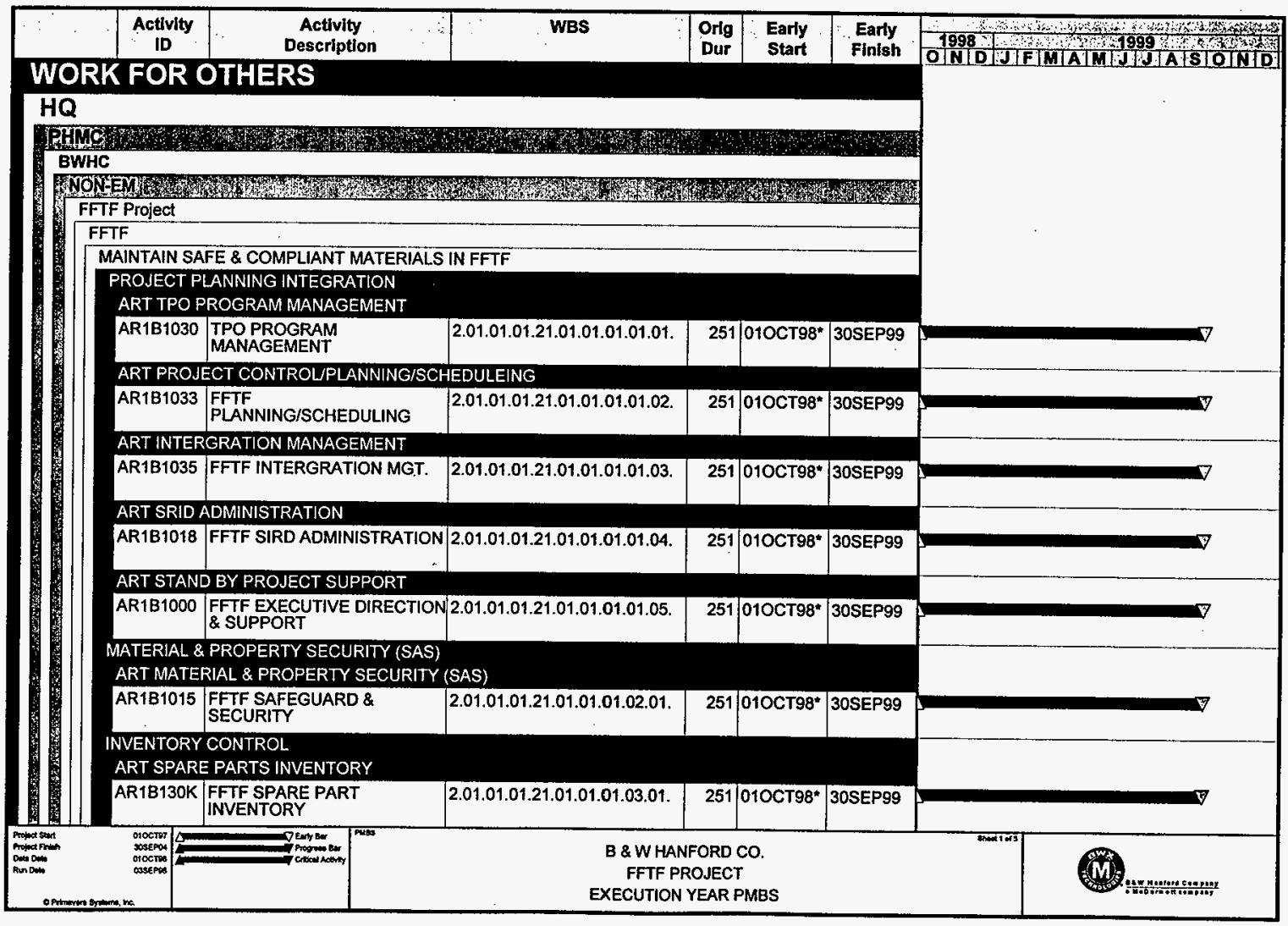




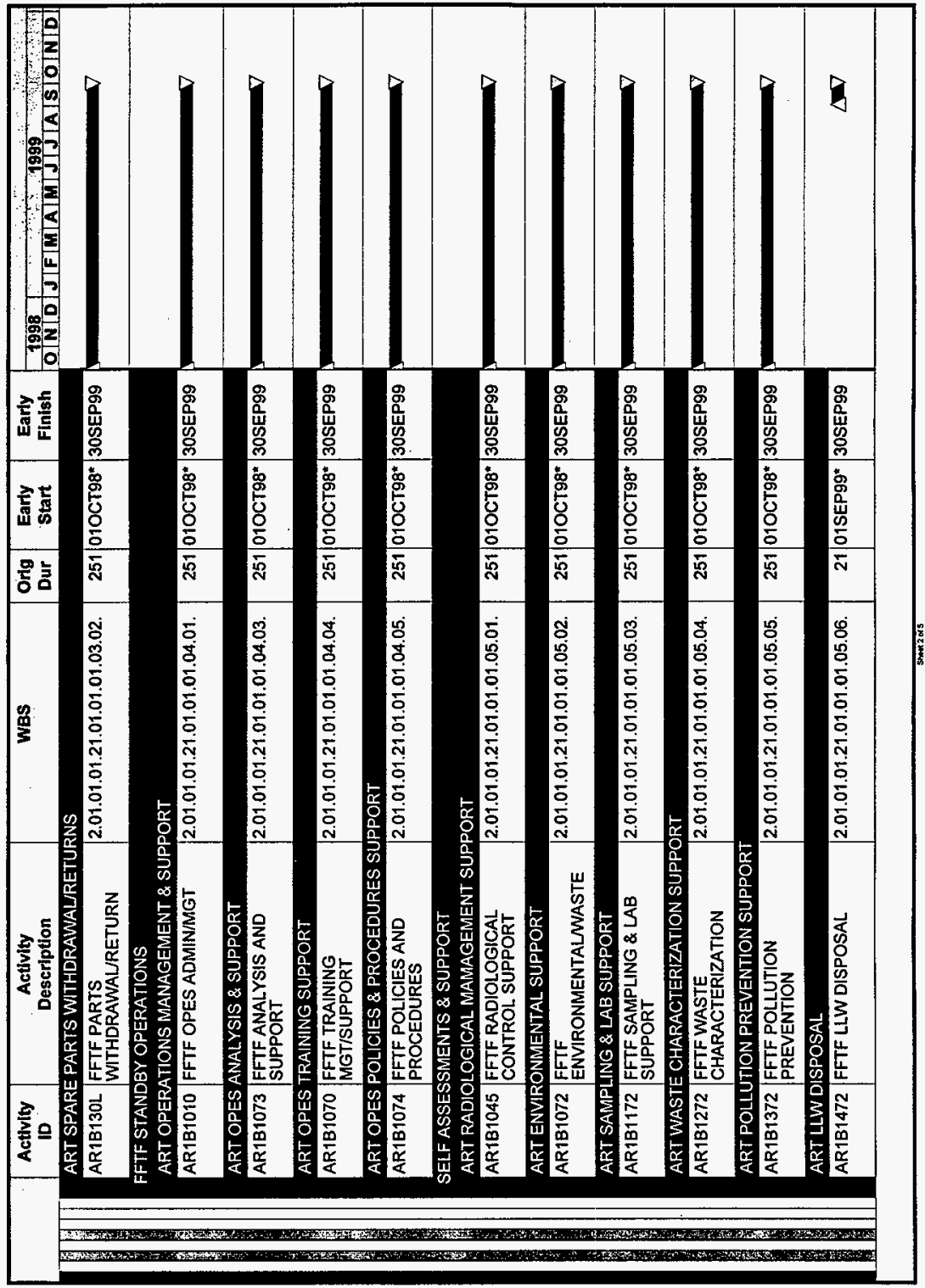




\begin{tabular}{|c|c|c|c|c|c|c|c|}
\hline & $\begin{array}{l}\text { Activity } \\
\text { ID }\end{array}$ & $\begin{array}{l}\text { Activity } \\
\text { Description }\end{array}$ & WBS & \begin{tabular}{|l|} 
Orig \\
Dur
\end{tabular} & $\begin{array}{l}\text { Early } \\
\text { Start }\end{array}$ & $\begin{array}{l}\text { Early } \\
\text { Finish }\end{array}$ & 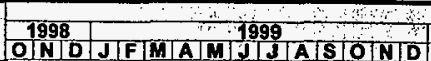 \\
\hline 11 & ART WAS & E DISPOSAL & & & & & \\
\hline 望 & AR1B1572 & $\begin{array}{l}\text { FFTF QUARTERLY WASTE } \\
\text { DISPOSAL }\end{array}$ & 2.01.01.01.21.01.01.01.05.07 & 209 & 02DEC98* & 30SEP99 & \\
\hline 蕆 & ART SAFE & TY SUPPORT & & & & & \\
\hline 国 & AR1B1080 & FFTF SAFETY SUPPORT & 2.01 .01 .01 .21 .01 .01 .01 .05 .08 & 251 & 010CT98* & 30SEP99 & $\nabla$ \\
\hline 四 & ART QUAL & ITY ASSURANCE & & & & & \\
\hline 筮 & AR1B1040 & $\begin{array}{l}\text { FFTF QUALITY ASSURANCE } \\
\text { SUPPORT }\end{array}$ & 2.01.01.01.21.01.01.01.05.09 & 251 & 010СT98" & 30SEP99 & \\
\hline 浆 & $\begin{array}{l}\text { MAINTAIN F } \\
\text { ART ENGI }\end{array}$ & $\begin{array}{l}\text { FTF SYST DESIGN } \\
\text { VEERING MANAGEMENT SUP }\end{array}$ & PORT & & & & \\
\hline 閣 & AR1B130A & $\begin{array}{l}\text { FFTF ENGINEERING } \\
\text { MANAGEMENT }\end{array}$ & 2.01.01.01.21.01.01.01.06.01 & 251 & $010 \mathrm{CT} 98^{*}$ & 30 SEP99 & \\
\hline 的 & ART AUX & YYSTEMS ELECTIRICAL ENGS & SUPPORT & & & & \\
\hline 篦 & AR1B1024 & $\begin{array}{l}\text { FFTF AUX SYSTEMS } \\
\text { ELECTRICAL SUPPORT }\end{array}$ & 2.01 .01 .01 .21 .01 .01 .01 .06 .02 & 251 & 010CT98* & 30 SEP99 & \\
\hline 周 & ART MECF & INICAL EQUIP \& INSPECT SUF & PORT & & & & \\
\hline trin & AR1B1023 & $\begin{array}{l}\text { FFTF MECHANICAL } \\
\text { ENGINEERING SUPPORT }\end{array}$ & 2.01.01.01.21.01.01.01.06.03 & 251 & 010СT98* & 30SEP99 & \\
\hline 9 & ART RSM & ENGINEERING MANAGEMENT & SUPPORT & & & & \\
\hline 斑 & AR1B1022 & $\begin{array}{l}\text { FFTF RSM ENGINEERING } \\
\text { SUPPORT }\end{array}$ & 2.01.01.01.21.01.01.01.06.04 & 251 & 010Ст98" & 30SEP99 & \\
\hline 18 & ART RSB & ROOF RECOATING \& INSPECT & ION & & & & \\
\hline 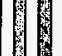 & AR1B1123 & $\begin{array}{l}\text { RSB ROOF RECOATING \& } \\
\text { INSPECTION }\end{array}$ & 2.01.01.01.21.01.01.01.06.05 & 251 & 010СT98* & 30SEP99 & \\
\hline 惫 & ART T196 & AIR DRYER HARD PIPING & & & & & \\
\hline 简 & AR1B1223 & $\begin{array}{l}\text { FFTF T-196 AIR DRYER HARI } \\
\text { PIPING }\end{array}$ & 2.01 .01 .01 .21 .01 .01 .01 .06 .06 & 251 & 010СT98* & 30SEP99 & \\
\hline & ART G-3 G & ENERATOR REPAIR/MATERIA & L PURCHASESE & & & & \\
\hline 望 & AR1B102A & $\begin{array}{l}\text { FFTF G-3 GENERATOR } \\
\text { REPAIRS/PURCHASE }\end{array}$ & 2.01.01.01.21.01.01.01.06.07 & 80 & O2NOV98* & O1MAR99 & \\
\hline 鼠 & G-3 FUEL & DIL LEAK DETECTOR & & & & & \\
\hline 望 & AR1B1025 & $\begin{array}{l}\text { G-3 FUEL.OIL TANK LEAK } \\
\text { DETECTION }\end{array}$ & 2.01.01.01.21.01.01.01.06.08 & 12 & O7DEC98* & 22DEC98 & \\
\hline 梦 & ARSE0078 & $\begin{array}{l}\text { B10-99-002 G-3 FUEL OIL. } \\
\text { TANK LEAK DETECTOR }\end{array}$ & 2.01 .01 .01 .21 .01 .01 .01 .06 .08 & 0 & & 22DEC98 & ROX $\$ B 10-99-002$ \\
\hline
\end{tabular}




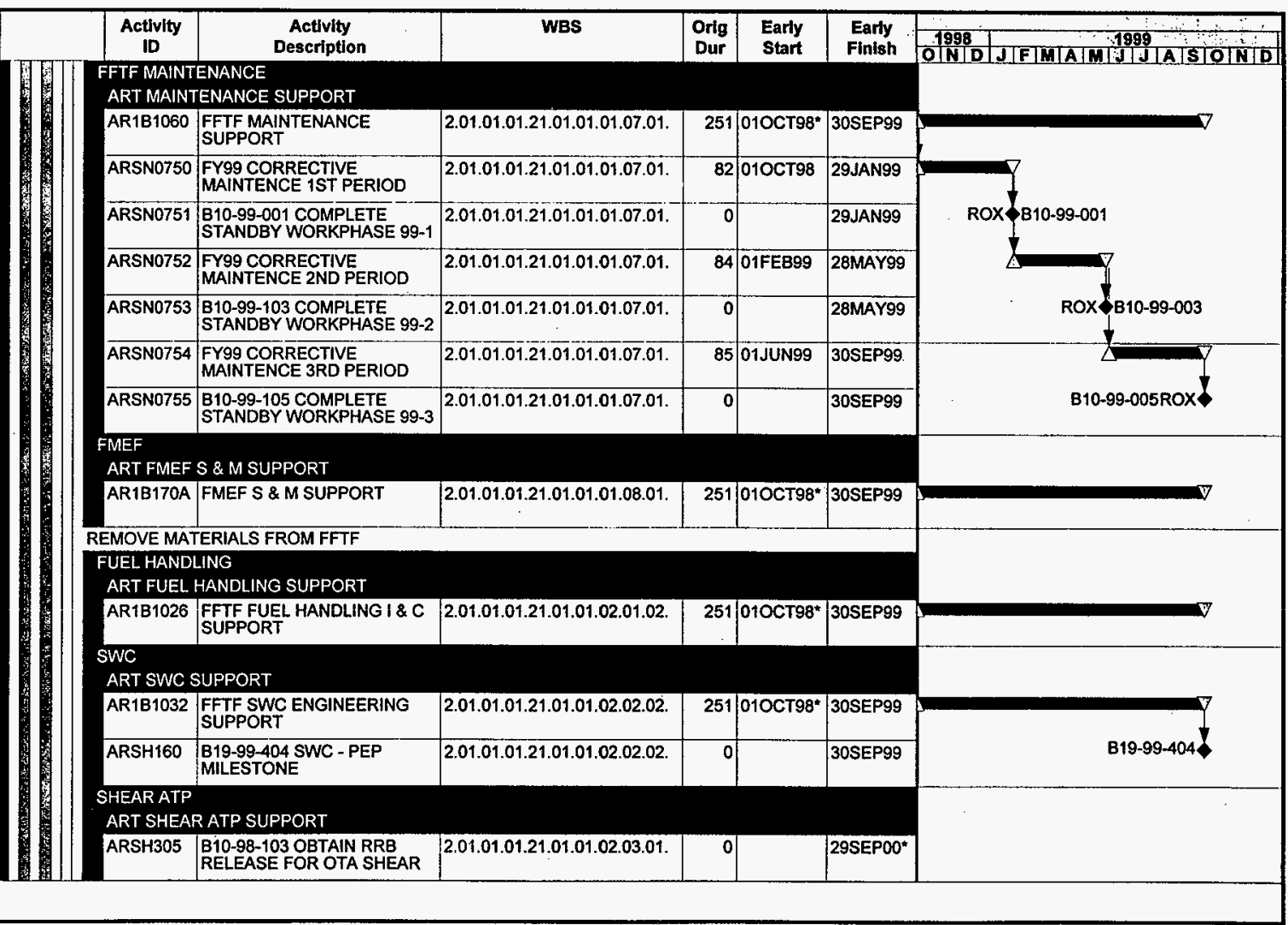




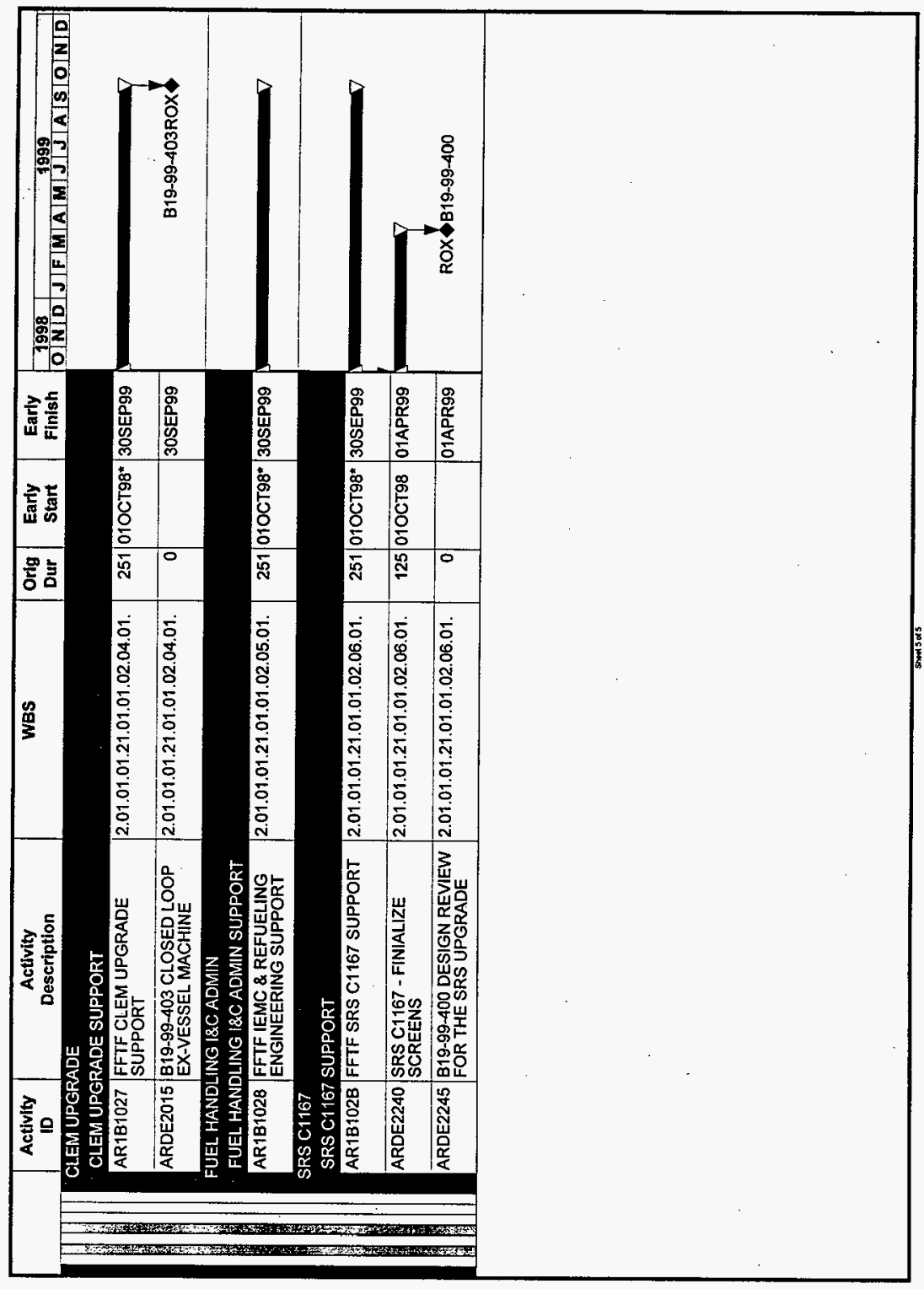




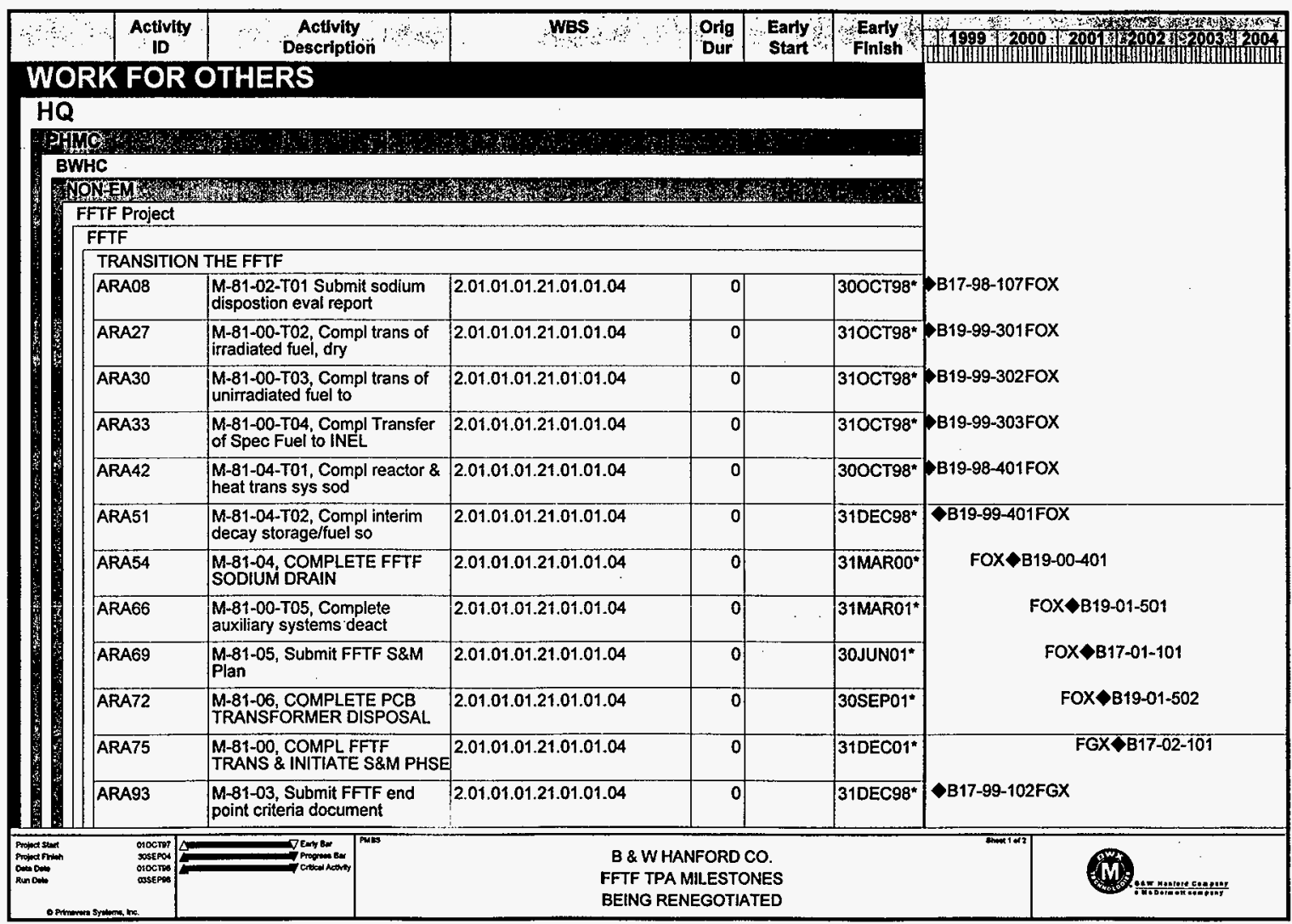




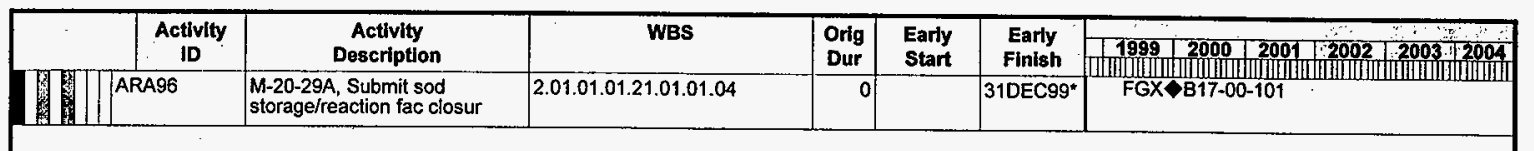




\begin{tabular}{|c|c|c|c|}
\hline MILESTONE & TPA-MS & IPA & MS \\
\hline COHTROL \# & NUMBER & TYPE & LEVEL \\
\hline 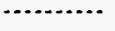 & 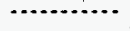 & $\cdots$ & $\cdots$ \\
\hline $819-98-401$ & $M=81-04-T 01$ & $\mathbf{T}$ & FO \\
\hline $817-98-107$ & $M-81-02-501$ & $\boldsymbol{T}$ & FO \\
\hline B $10-99-001$ & & & $\mathrm{RL}$ \\
\hline $819-99-400$ & ? & & $R L$ \\
\hline B 19.99 .403 & & & $R L$ \\
\hline B19-99-404 & & & $R L$ \\
\hline$B 10-99-002$ & & & $\mathrm{RL}$ \\
\hline $810-99-003$ & & & RL \\
\hline $810-99-005$ & & & $\mathrm{RL}$ \\
\hline B19-01-501 & $M-81-00-T 05$ & $\mathbf{T}$ & Fo \\
\hline $817-01-101$ & $M-81-05$ & 1 & FO \\
\hline B $10-98-103$ & & & $\mathbf{R L}$ \\
\hline $819 \cdot 99 \cdot 301$ & M-81-00-T02 & T & FO \\
\hline B19-99-302 & $M-81-00-T 03$ & $T$ & Fo \\
\hline$B 17-00-101$ & $M-20-29 A$ & 1 & Fo \\
\hline $819-99 \cdot 303$ & $H-81-00-104$ & $T$ & Fo \\
\hline B19-99-401 & $M-81-04-T 02$ & $T$ & FO \\
\hline$B 19-00 \cdot 401$ & $N=81-04$ & 1 & Fo \\
\hline B19-01-502 & k-81-06 & 1 & fo \\
\hline $817-99-102$ & $M-81-03$ & I & Fo \\
\hline $817 \cdot 02 \cdot 101$ & $M-81-00$ & N & fo \\
\hline
\end{tabular}

MS TITLE

COMPLETE REACTOR AND HEAT TRAKSPORT SYSTEM SOOIUM DRAIN SUBMIT SODIUM OISPOSITION EVALUATION REPORT/DECISION POINT COMPLETE STANDBY WORKPHASE $99-1$

DESIGN REVIEH FOR THE SCOIUM REMOVAL SYSTEM UPGRADE

CLOSED LOOP EX-VESSEL MACHIME CONTROL SYSTEM UPGRADE

UPGRADE THE SOL ID WASTE CASK (SWC)

G-3 FUEL OIL, TAHK LEAK DETECTION

COMPLETE STANDBY WORKPHASE $99-2$

COMPLETE STANDBY WORKPHASE $99-3$

COMPLETE AUXILIARY SYSTEMS DEACTIVATION

SUBMIT FFTF SURVEILLANCE AND MAINTENANCE PLAN

OBTALN RRB RELEASE FOR OTA SHEAR OPERATION

COMPLETE IRANSFER OF IRRADIATED FUEL TO DRY CASK STORAGE

COMPLETE TRANSFER OF UNTRRADIATED FUEL TO PFP

SUBMIT SOOIUM STORAGE FACILITY \& SOOIUM REACTION FACIL CLOSURE PL

COMPLEIE IRANSFER OF SPECIAL FUEL TO IHEL FOR STORAGE

COMPLETE TNTERIM DECAY STORAGE/FUEL STORAGE FACILITY SOOIUM DRAIN COMPLETE FFTF SOOIUM DRAIN

COMPLETE PCB TRANSFORMER DISPOSAL

SUBMIT FFTF END POINT CRITERIA DOCUMENT

COMPLETE FFTF TRANSITION AND INITIATE THE S\&M PHASE
-......DATES

TYPE -... ort

OTH

$4 / 30 / 98$

$6 / 30 / 98$

$1 / 31 / 99$

$4 / 01 / 99$

$9 / 30 / 99$

$9 / 30 / 99$

$12 / 22 / 98$

$5 / 31 / 99$

$9 / 30 / 99$

orit $3 / 31 / 01$

EA $6 / 30 / 01$

OTH $9 / 30 / 00$

OTH $10 / 22 / 98$

OTH $10 / 22 / 98$

EA $12 / 31 / 90$

OTH $10 / 22 / 98$

OTH $12 / 31 / 98$

EA $3 / 14 / 00$

EA $\quad 9 / 30 / 01$

EA $12 / 31 / 98$

EA $12 / 31 / 0$
TPA/DNFSB

COMAIT

DNFSB TIP PBS \#

-...

N RL-MSOT

N RL-MSO1

N RL-MSO1

N RL-MSO1

N RL-MSO1

N RL-MSO1

N RL-MSO1

N RL-MSO1

N RL-MSO1

N RL-MSO1

N RL-MSO1

$6 / 30 / 01$

$10 / 09 / 98$

$10 / 31 / 98$

$10 / 31 / 98$

$12 / 31 / 49$

$10 / 31 / 98$

$12 / 31 / 98$

$3 / 31 / 00$

9/30/01

$12 / 31 / 98$

$\lceil 2 / 31 / 01$ 


\section{PHMC \\ MILESTONE DESCRIPTION SHEET}

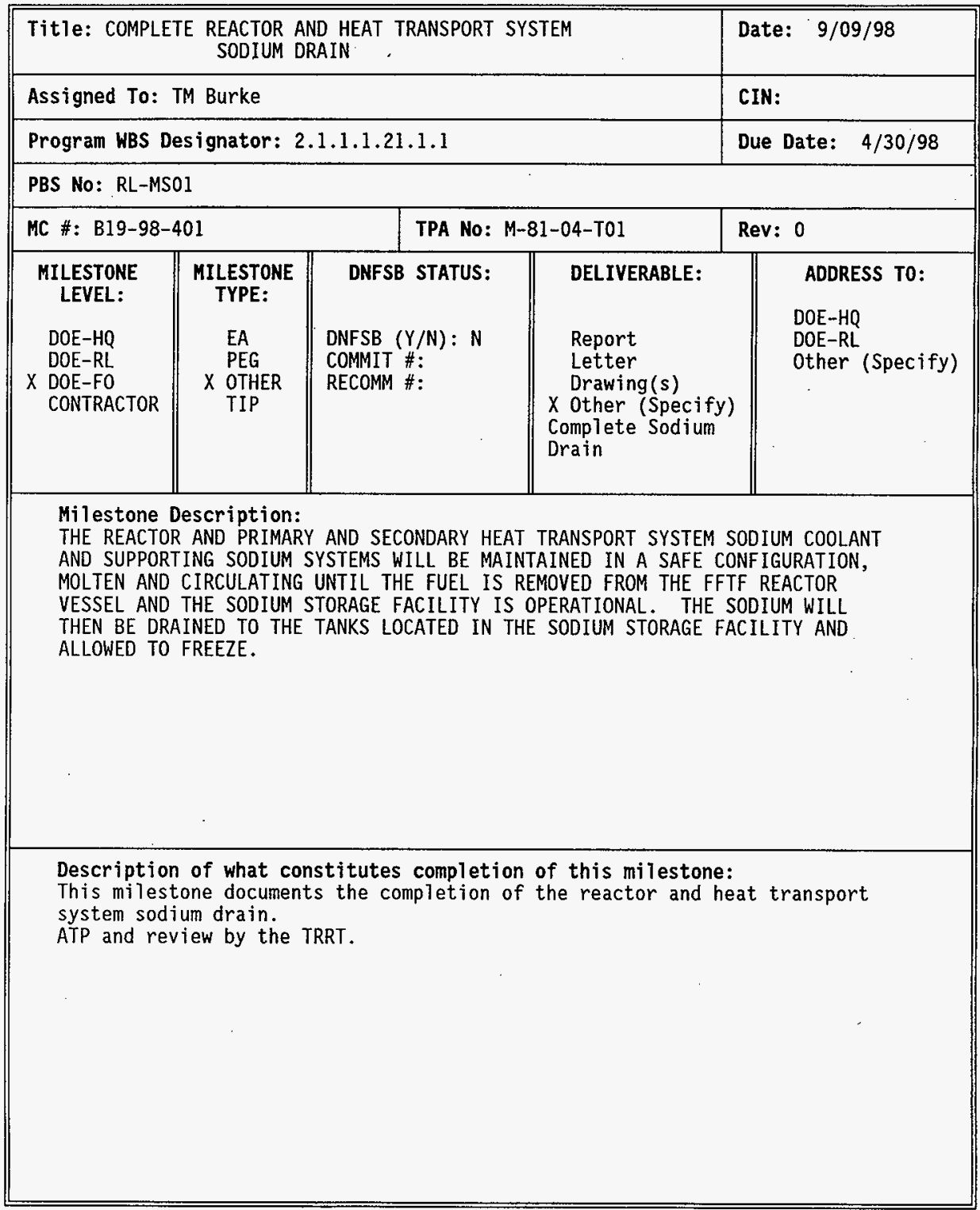


PHMC

MILESTONE DESCRIPTION SHEET

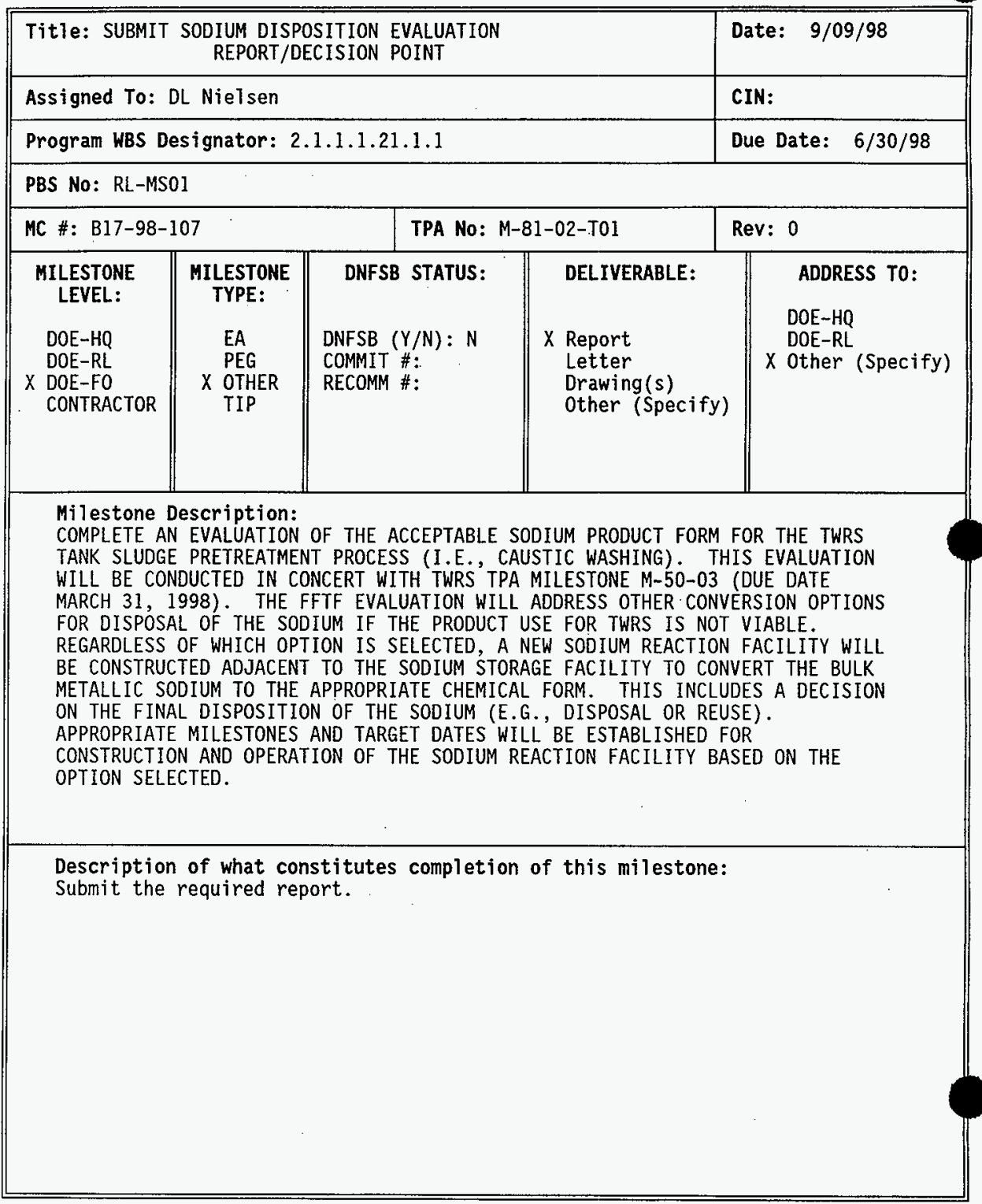




\section{PHMC}

MILESTONE DESCRIPTION SHEET

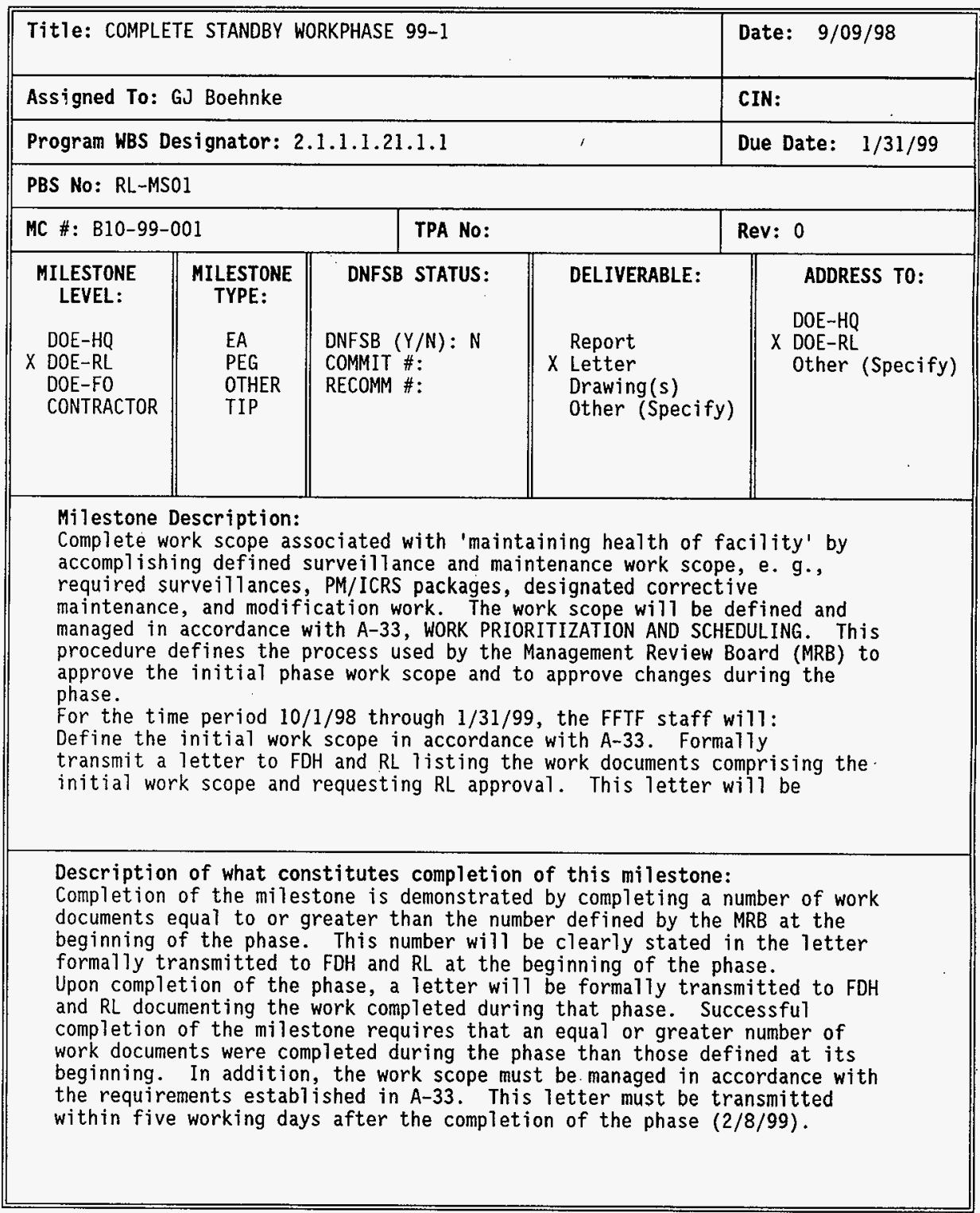




\section{PHMC}

\section{MILESTONE DESCRIPTION SHEET}

Program WBS Designator: 2.1.1.1.21.1.1

HC \# : B10-99-001

Milestone description: (con't)

transmitted within five working days from the beginning of the phase $(10 / 7)$.

Manage the work scope during the phase in accordance with A-33. (The MRB will approve additions and deletions to the scope as authorized in A33.)

Complete the required surveillances and PM/ICRS packages at their required frequencies.

Complete a number of work documents equal to or greater than the number in the originally defined scope for the phase. 


\section{PHMC}

\section{MILESTONE DESCRIPTION SHEET}

\begin{tabular}{|c|c|c|c|c|}
\hline \multicolumn{4}{|c|}{$\begin{array}{c}\text { Title: DESIGN REVIEW FOR THE SODIUM REMOVAL SYSTEM } \\
\text { UPGRADE }\end{array}$} & Date: $9 / 09 / 98$ \\
\hline \multicolumn{4}{|c|}{ Assigned To: GN Ruge } & CIN: \\
\hline \multicolumn{4}{|c|}{ Program WBS Designator: 2.1.1.1.21.1.1 } & Due Date: $4 / 01 / 99$ \\
\hline \multicolumn{5}{|c|}{ PBS No: RL-MSO1 } \\
\hline \multicolumn{2}{|c|}{ MC \#: B19-99-400 } & TPA No: & & Rev: 0 \\
\hline $\begin{array}{l}\text { MILESTONE } \\
\text { LEVEL: } \\
\text { DOE-HQ } \\
\text { X DOE-RL } \\
\text { DOE-FO } \\
\text { CONTRACTOR }\end{array}$ & $\begin{array}{l}\text { MILESTONE } \\
\text { TYPE: } \\
\text { EA } \\
\text { PEG } \\
\text { OTHER } \\
\text { TIP }\end{array}$ & $\begin{array}{l}\text { DNFSB STATUS: } \\
\text { DNFSB }(Y / N): N \\
\text { COMMIT \#: } \\
\text { RECOMM \#: }\end{array}$ & $\begin{array}{l}\text { DELIVERABLE: } \\
\text { Report } \\
\text { X Letter } \\
\text { Drawing(s) } \\
\text { Other (Specify) }\end{array}$ & $\begin{array}{l}\text { ADDRESS TO: } \\
\text { DOE-HQ } \\
\times \text { DOE-RL } \\
\text { Other (Specify) }\end{array}$ \\
\hline \multicolumn{5}{|c|}{$\begin{array}{l}\text { Milestone Description: } \\
\text { Complete the design of upgrades to the Interim Examination and Maintenance } \\
\text { (IEM) Cell Sodium Removal System (SRS) control system, panel C-1167. The } \\
\text { upgrades will enhance the man-machine interface, the system reliability and } \\
\text { maintainability, and the safety of performing maintenance. The definitive } \\
\text { design shall be developed and a design review conducted in accordance with } \\
\text { applicable engineering design procedures. }\end{array}$} \\
\hline \multicolumn{5}{|c|}{$\begin{array}{l}\text { Description of what constitutes completion of this milestone: } \\
\text { The design review shali be completed and documented in a final design } \\
\text { review report. Completion of the milestone shall be documented by letter } \\
\text { to the RL-SPO. }\end{array}$} \\
\hline
\end{tabular}


PHMC

MILESTONE DESCRIPTION SHEET

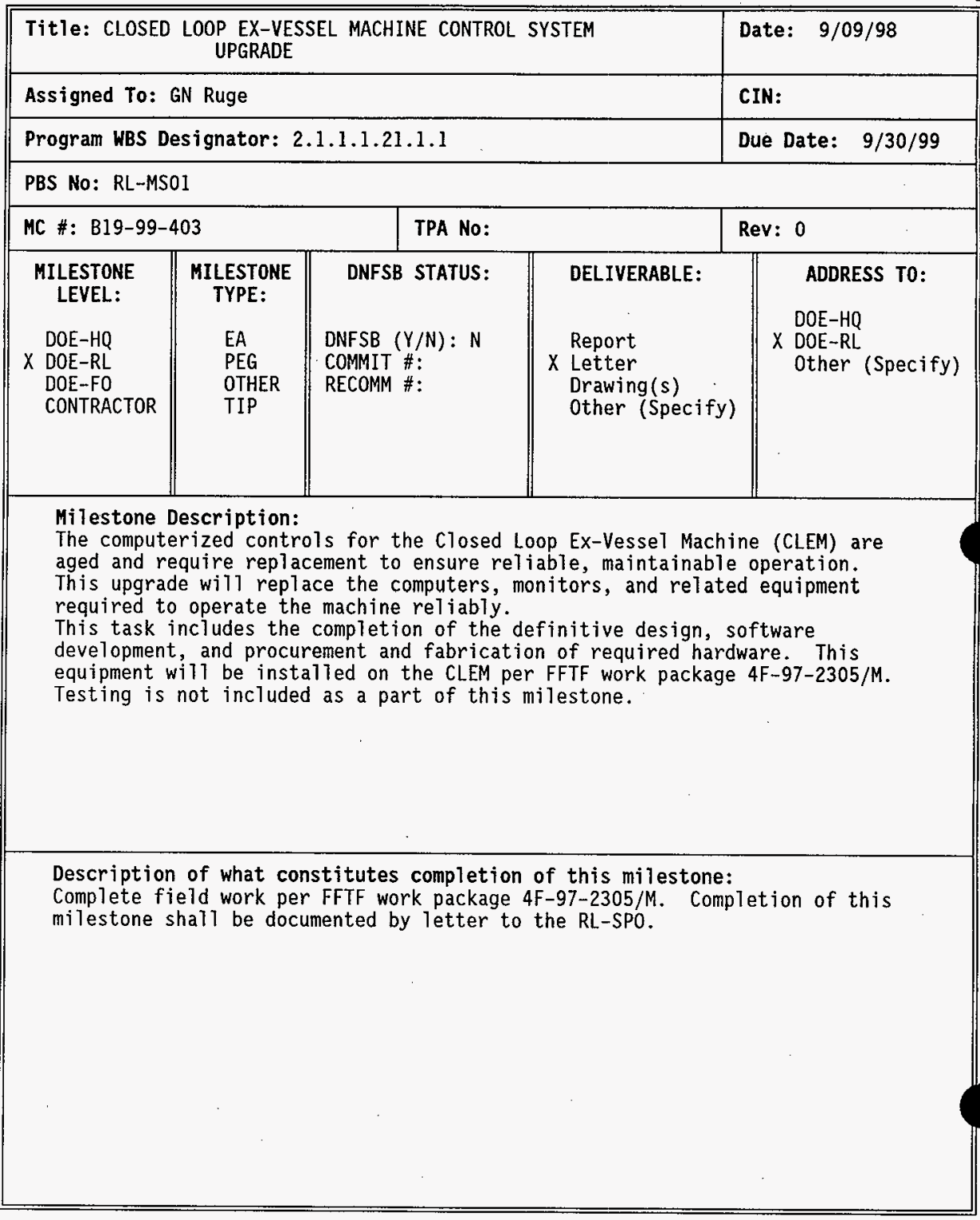




\section{PHMC \\ MILESTONE DESCRIPTION SHEET}

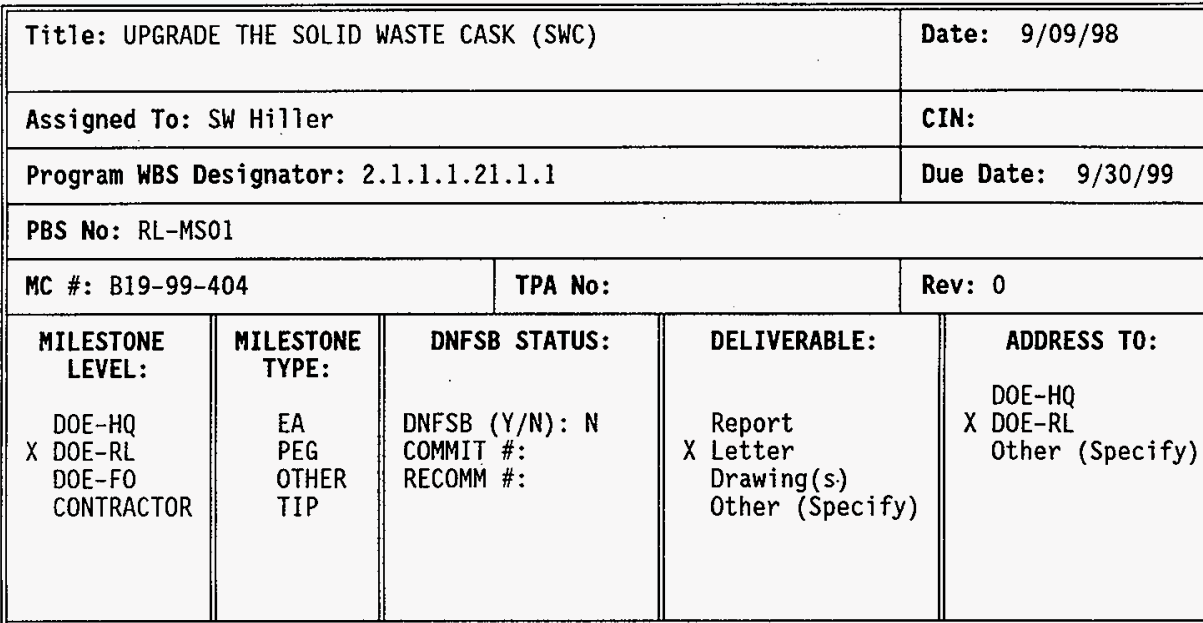

Milestone Description:

Complete the design, procurement, and shop fabrication of the SWC hoist and grapple systems.

Description of what constitutes completion of this milestone:

The status of the SWC upgrade shall be reported to the RL-SPO by letter, documenting that the above activities are complete. 


\section{PHMC}

MILESTONE DESCRIPTION SHEET

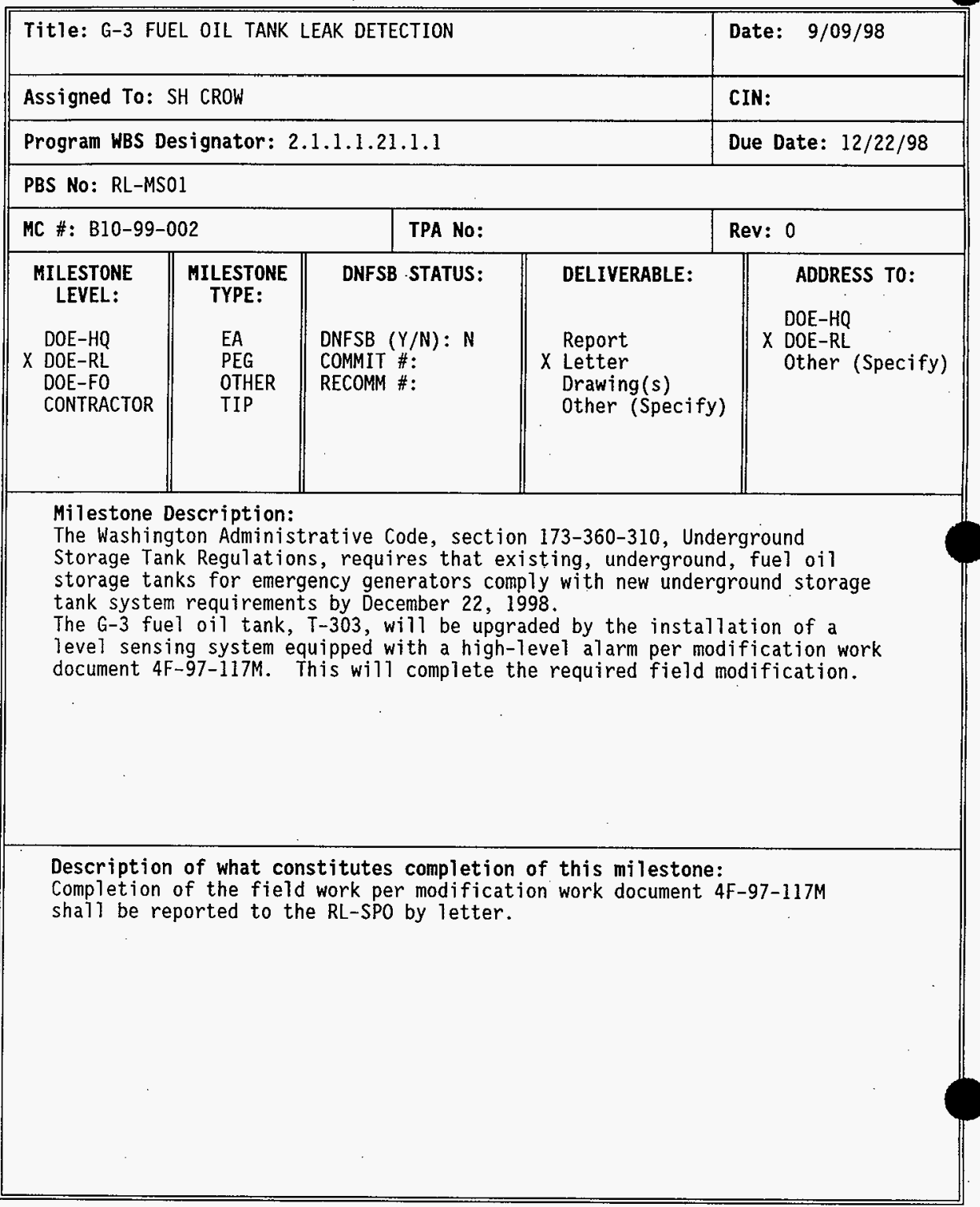




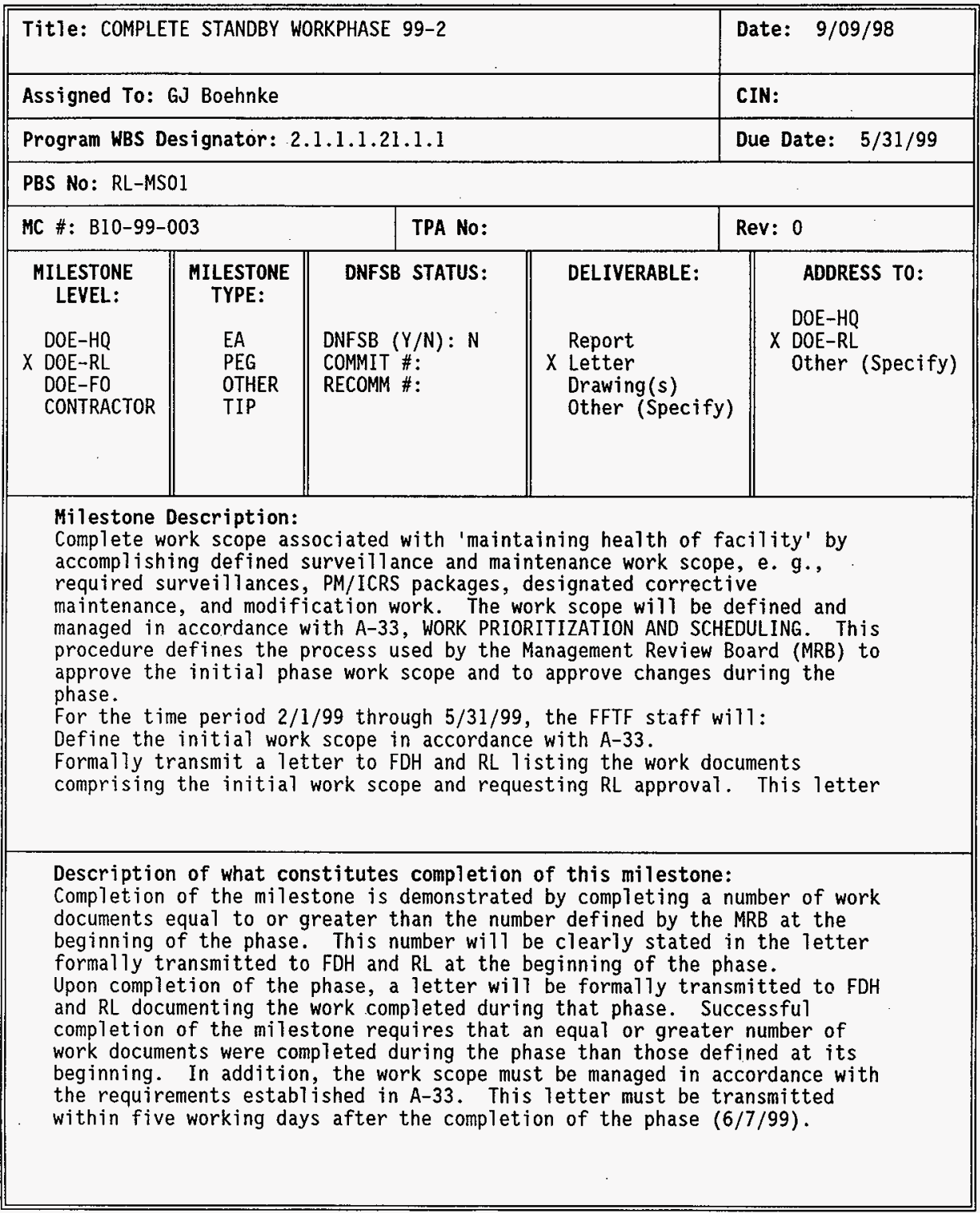




\section{PHMC \\ MILESTONE DESCRIPTION SHEET}

Program WBS Designator: 2.1.1.1.21.1.1

MC \#: B10-99-003

Milestone description: (con't)

will be transmitted within five working days from the beginning of the phase $(2 / 8 / 99)$.

Manage the work scope during the phase in accordance with A-33. (The MRB will approve additions and deletions to the scope as authorized in A33.)

Complete the required surveillances and PM/ICRS packages at their required frequencies.

Complete a number of work documents equal to or greater than the number in the originally defined scope for the phase. 


\section{PHMC}

MILESTONE DESCRIPTION SHEET

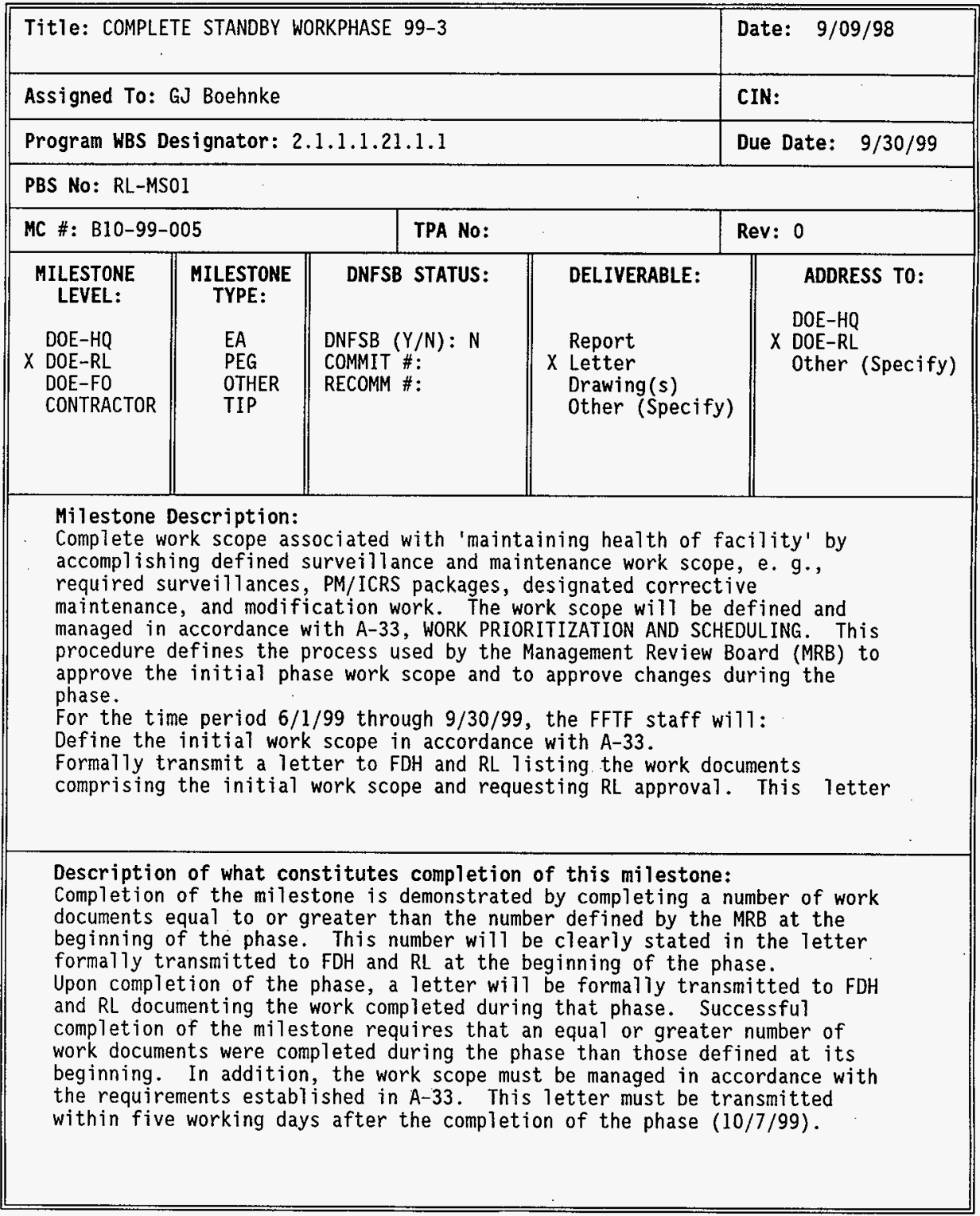




\section{PHMC}

\section{Continuation Page}

Program WBS Designator: 2.1.1.1.21.1.1

MC \#: B10-99-005

Milestone description: (con't)

will be transmitted within five working days from the beginning of the phase $(6 / 7 / 99)$.

Manage the work scope during the phase in accordance with A-33. (The MRB will approve additions and deletions to the scope as authorized in A-33.)

Complete the required surveillances and PM/ICRS packages at their required frequencies.

Complete a number of work documents equal to or greater than the number in the originally defined scope for the phase. 


\section{PHMC}

MILESTONE DESCRIPTION SHEET

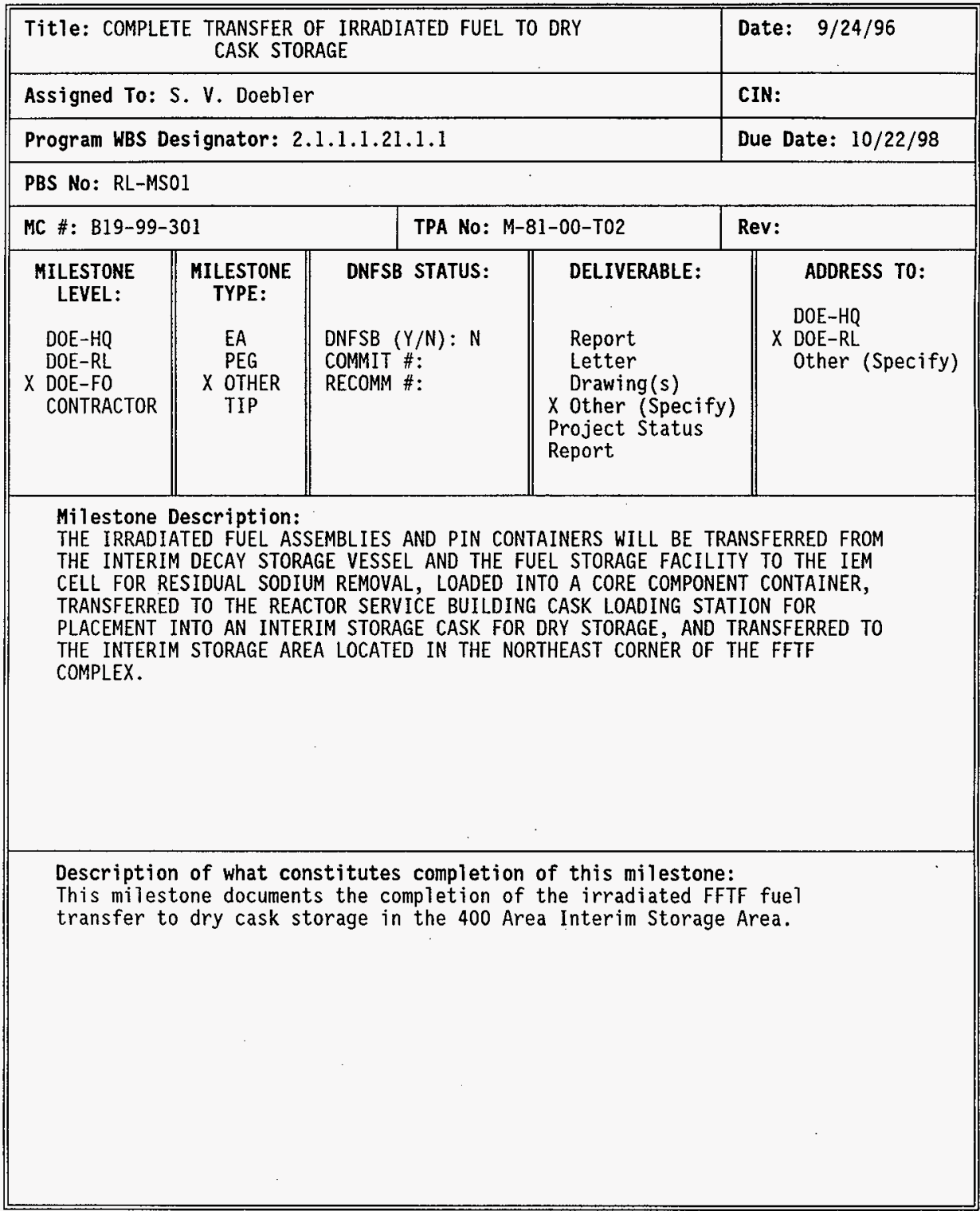


PHMC

MILESTONE DESCRIPTION SHEET

\begin{tabular}{|c|c|c|c|c|}
\hline \multicolumn{4}{|c|}{$\begin{array}{c}\text { Title: SUBMIT SODIUM STORAGE FACILITY \& SODIUM } \\
\text { REACTION FACIL CLOSURE PL }\end{array}$} & Date: $9 / 24 / 96$ \\
\hline \multicolumn{4}{|c|}{ Assigned To: R. K. Hulvey } & CIN: \\
\hline \multicolumn{4}{|c|}{ Program WBS Designator: 2.1.1.1.21.1.1 } & Due Date: $12 / 31 / 99$ \\
\hline \multicolumn{5}{|c|}{ PBS No: RL-MSO1 } \\
\hline \multicolumn{2}{|c|}{ MC \#: B17-00-101 } & \multicolumn{2}{|c|}{ TPA No: M-20-29A } & Rev: \\
\hline $\begin{array}{l}\text { MILESTONE } \\
\text { LEVEL: } \\
\text { DOE-HQ } \\
\text { DOE-RL } \\
\text { X DOE-FO } \\
\text { CONTRACTOR }\end{array}$ & $\begin{array}{l}\text { MILESTONE } \\
\text { TYPE: } \\
\text { X EA } \\
\text { PEG } \\
\text { OTHER } \\
\text { TIP }\end{array}$ & $\begin{array}{l}\text { DNFSB STATUS: } \\
\text { DNFSB }(Y / N): N \\
\text { COMMIT \#: } \\
\text { RECOMM \#: }\end{array}$ & $\begin{array}{l}\text { DELIVERABLE: } \\
\text { Report } \\
\times \text { Letter } \\
\text { Drawing(s) } \\
\text { Other (Specify) }\end{array}$ & $\begin{array}{l}\text { ADDRESS TO: } \\
\text { DOE-HQ } \\
\times \text { DOE-RL } \\
\text { Other (Specify) }\end{array}$ \\
\hline \multicolumn{5}{|c|}{$\begin{array}{l}\text { Milestone Description: } \\
\text { Submit Sodium Storage Facility and Sodium Reaction Facility closure plan or } \\
\text { request for procedural closure as defined in Section } 6.3 .3 \text { of this Tri- } \\
\text { Party Agreement to EPA and Ecology. }\end{array}$} \\
\hline \multicolumn{5}{|c|}{$\begin{array}{l}\text { Description of what constitutes completion of this milestone: } \\
\text { If the sodium use for TWRS is confirmed, a request for procedural closure } \\
\text { as defined in Section } 6.3 .3 \text { of the Tri-Party Agreement will be submitted } \\
\text { for the Sodium Storage Facility and the Sodium Reaction Facility units. If } \\
\text { the sodium is determined to be a waste, a closure plan will be submitted } \\
\text { for the two units. }\end{array}$} \\
\hline
\end{tabular}


PHMC

MILESTONE DESCRIPTION SHEET

\begin{tabular}{|c|c|c|c|c|}
\hline \multicolumn{4}{|c|}{$\begin{array}{l}\text { Title: COMPLETE TRANSFER OF SPECIAL FUEL TO INEL } \\
\text { FOR STORAGE }\end{array}$} & Date: $9 / 24 / 96$ \\
\hline \multicolumn{4}{|c|}{ Assigned To: S. V. Doebler } & CIN: \\
\hline \multicolumn{4}{|c|}{ Program WBS Designator: 2.1.1.1.21.1.1 } & Due Date: $10 / 22 / 98$ \\
\hline \multicolumn{5}{|c|}{ PBS No: RL-MSO1 } \\
\hline \multicolumn{2}{|c|}{ MC \#: B19-99-303 } & \multicolumn{2}{|c|}{ TPA No: M-81-00-T04 } & Rev: \\
\hline $\begin{array}{l}\text { MILESTONE } \\
\text { LEVEL: } \\
\text { DOE-HQ } \\
\text { DOE-RL } \\
\text { X DOE-FO } \\
\text { CONTRACTOR }\end{array}$ & $\begin{array}{l}\text { MILESTONE } \\
\text { TYPE: } \\
\text { EA } \\
\text { PEG } \\
\text { X OTHER } \\
\text { TIP }\end{array}$ & $\begin{array}{l}\text { DNFSB STATUS: } \\
\text { DNFSB }(Y / N): N \\
\text { COMMIT \#: } \\
\text { RECOMM \#: }\end{array}$ & $\begin{array}{l}\text { DELIVERABLE: } \\
\\
\text { Report } \\
\text { Letter } \\
\text { Drawing(s) } \\
\text { x Other (Specify) } \\
\text { Project Status } \\
\text { Report }\end{array}$ & $\begin{array}{l}\text { ADDRESS TO: } \\
\text { DOE-HQ. } \\
\text { X DOE-RL } \\
\text { Other (Specify) }\end{array}$ \\
\hline \multicolumn{5}{|c|}{$\begin{array}{l}\text { Milestone Description: } \\
\text { SODIUM-BONDED IRRADIATED METAL AND CARBIDE FUEL PINS FROM ASSEMBLIES } \\
\text { CLEANED AND DISASSEMBLED IN THE IEM CELL WILL BE LOADED INTO EXISTING, } \\
\text { APPROVED SHIPPING CASKS, AND TRANSPORTED TO THE IDAHO NATIONAL ENGINEERING } \\
\text { LABORATORY IN IDAHO FALLS, IDAHO, FOR CONSOL IDATED STORAGE. ONE } \\
\text { UNIRRADIATED METAL FUEL ASSEMBLY WILL ALSO BE DISPOSITIONED IN A SIMILAR } \\
\text { MANNER. }\end{array}$} \\
\hline \multicolumn{5}{|c|}{$\begin{array}{l}\text { Description of what constitutes completion of this milestone: } \\
\text { This milestone documents the completion of the transfer of the special fuel } \\
\text { to Idaho Nuclear Engineering Laboratory (INEL). Note: There is currently } \\
\text { a Concent Order which delays shipping this special fuel to INEL until after } \\
\text { December } 31,2000 \text {. }\end{array}$} \\
\hline
\end{tabular}




\section{PHMC \\ MILESTONE DESCRIPTION SHEET}

\begin{tabular}{|c|c|c|c|c|}
\hline \multicolumn{4}{|c|}{$\begin{array}{c}\text { Title: COMPLETE INTERIM DECAY STORAGE/FUEL STORAGE } \\
\text { FACILITY SODIUM DRAIN }\end{array}$} & Date: $9 / 24 / 96$ \\
\hline \multicolumn{4}{|c|}{ Assigned To: T. M. Burke } & CIN: \\
\hline \multicolumn{4}{|c|}{ Program WBS Designator: 2.1.1.1.21.1.1 } & Due Date: $12 / 31 / 98$ \\
\hline \multicolumn{5}{|c|}{ PBS No: RL-MSOI } \\
\hline \multicolumn{2}{|c|}{ MC \#: B19-99-401 } & \multicolumn{2}{|c|}{ TPA No: M-81-04-T02 } & Rev: \\
\hline $\begin{array}{l}\text { MILESTONE } \\
\text { LEVEL: } \\
\text { DOE-HQ } \\
\text { DOE-RL } \\
\times \text { DOE-FO } \\
\text { CONTRACTOR }\end{array}$ & $\begin{array}{l}\text { MILESTONE } \\
\text { TYPE: } \\
\text { EA } \\
\text { PEG } \\
\times \text { OTHER } \\
\text { TIP }\end{array}$ & $\begin{array}{l}\text { DNFSB STATUS: } \\
\text { DNFSB }(Y / N): N \\
\text { COMMIT \#: } \\
\text { RECOMM \#: }\end{array}$ & $\begin{array}{l}\text { DELIVERABLE: } \\
\\
\text { Report } \\
\times \text { Letter } \\
\text { Drawing(s) } \\
\text { Other (Specify) }\end{array}$ & $\begin{array}{l}\text { ADDRESS TO: } \\
\text { DOE-HQ } \\
\times \text { DOE-RL } \\
\text { Other (Specify) }\end{array}$ \\
\hline \multicolumn{5}{|c|}{$\begin{array}{l}\text { Milestone Description: } \\
\text { THE INTERIM DECAY STORAGE VESSEL AND FUEL STORAGE FACILITY SODIUM WILL BE } \\
\text { MAINTAINED IN A MOLTEN STATE UNTIL THE FUEL IS REMOVED FROM THESE STORAGE } \\
\text { LOCATIONS. THE SODIUM WILL THEN BE DRAINED TO THE TANKS LOCATED IN THE } \\
\text { SODIUM STORAGE FACILITY AND ALLOWED TO FREEZE. }\end{array}$} \\
\hline \multicolumn{5}{|c|}{$\begin{array}{l}\text { Description of what constitutes completion of this milestone: } \\
\text { The Interim Decay Storage Vessel and the Fuel Storage Facility Vessel have } \\
\text { had all fueled components removed and the sodium drained to the extent } \\
\text { practical in accordance with the End Point Criteria Checklist. }\end{array}$} \\
\hline
\end{tabular}




\section{PHMC}

MILESTONE DESCRIPTION SHEET

\begin{tabular}{|c|c|c|c|c|}
\hline \multicolumn{4}{|c|}{$\begin{array}{c}\text { Title: COMPLETE FFTF SODIUM DRAIN } \\
:\end{array}$} & Date: $9 / 24 / 96$ \\
\hline \multicolumn{4}{|c|}{ Assigned To: T. M. Burke } & CIN: \\
\hline \multicolumn{4}{|c|}{ Program WBS Designator: 2.1.1.1.21.1.1 } & Due Date: $3 / 14 / 00$ \\
\hline \multicolumn{5}{|c|}{ PBS No: RL-MSOl } \\
\hline \multicolumn{2}{|c|}{ MC \#: B19-00-401 } & \multicolumn{2}{|c|}{ TPA No: M-81-04 } & Rev: \\
\hline $\begin{array}{l}\text { MILESTONE } \\
\text { LEVEL: } \\
\text { DOE-HQ } \\
\text { DOE-RL } \\
\text { X DOE-FO } \\
\text { CONTRACTOR }\end{array}$ & $\begin{array}{l}\text { MILESTONE } \\
\text { TYPE: } \\
\times \text { EA } \\
\text { PEG } \\
\text { OTHER } \\
\text { TIP }\end{array}$ & $\begin{array}{l}\text { DNFSB STATUS: } \\
\text { DNFSB }(Y / N): N \\
\text { COMMIT \#: } \\
\text { RECOMM \#: }\end{array}$ & $\begin{array}{l}\text { DELIVERABLE: } \\
\text { Report } \\
\text { X Letter } \\
\text { Drawing(s) } \\
\text { Other (Specify) }\end{array}$ & \begin{tabular}{|l} 
ADDRESS T0: \\
DOE-HQ \\
$\times$ DOE-RL \\
0ther (Specify)
\end{tabular} \\
\hline \multicolumn{5}{|c|}{$\begin{array}{l}\text { Milestone Description: } \\
\text { THIS MILESTONE WILL BE COMPLETE WHEN ALL OF THE SODIUM COOLANT HAS BEEN } \\
\text { DRAINED FROM THE PLANT TO THE NEW SODIUM STORAGE FACILITY TO THE MAXIMUM } \\
\text { PRACTICAL EXTENT. THE SODIUM RESIDUALS THAT REMAIN ARE INTEGRAL TO THE } \\
\text { SYSTEM, ARE SOLID IN FORM, AND ADHERE TO THE SURFACES OF THE SYSTEM } \\
\text { COMPONENTS. THE RESIDUALS WILL BE MAINTAINED UNDER AN INERT GAS BLANKET TO } \\
\text { MINIMIZE POTENTIAL REACTIONS DURING THE LONG-TERM SURVEILLANCE AND } \\
\text { MAINTENANCE PHASE. DURING FINAL DISPOSITION OF THE FACILITY, ANY REGULATED } \\
\text { WASTES GENERATED FROM THE CLEANING OR DISMANTLEMENT OF THESE SYSTEMS, WILL } \\
\text { BE APPROPRIATELY MANAGED. }\end{array}$} \\
\hline \multicolumn{5}{|c|}{$\begin{array}{l}\text { Description of what constitutes completion of this milestone: } \\
\text { The Heat Transport Systems, the reactor vessel, the IDS vessel, and the } \\
\text { Fuel Storage Facility, as well as supporting sodium systems, have been } \\
\text { drained to the extent practical, in accordance with the End Point Criteria } \\
\text { Checklist. }\end{array}$} \\
\hline
\end{tabular}




\section{PHMC}

MILESTONE DESCRIPTION SHEET

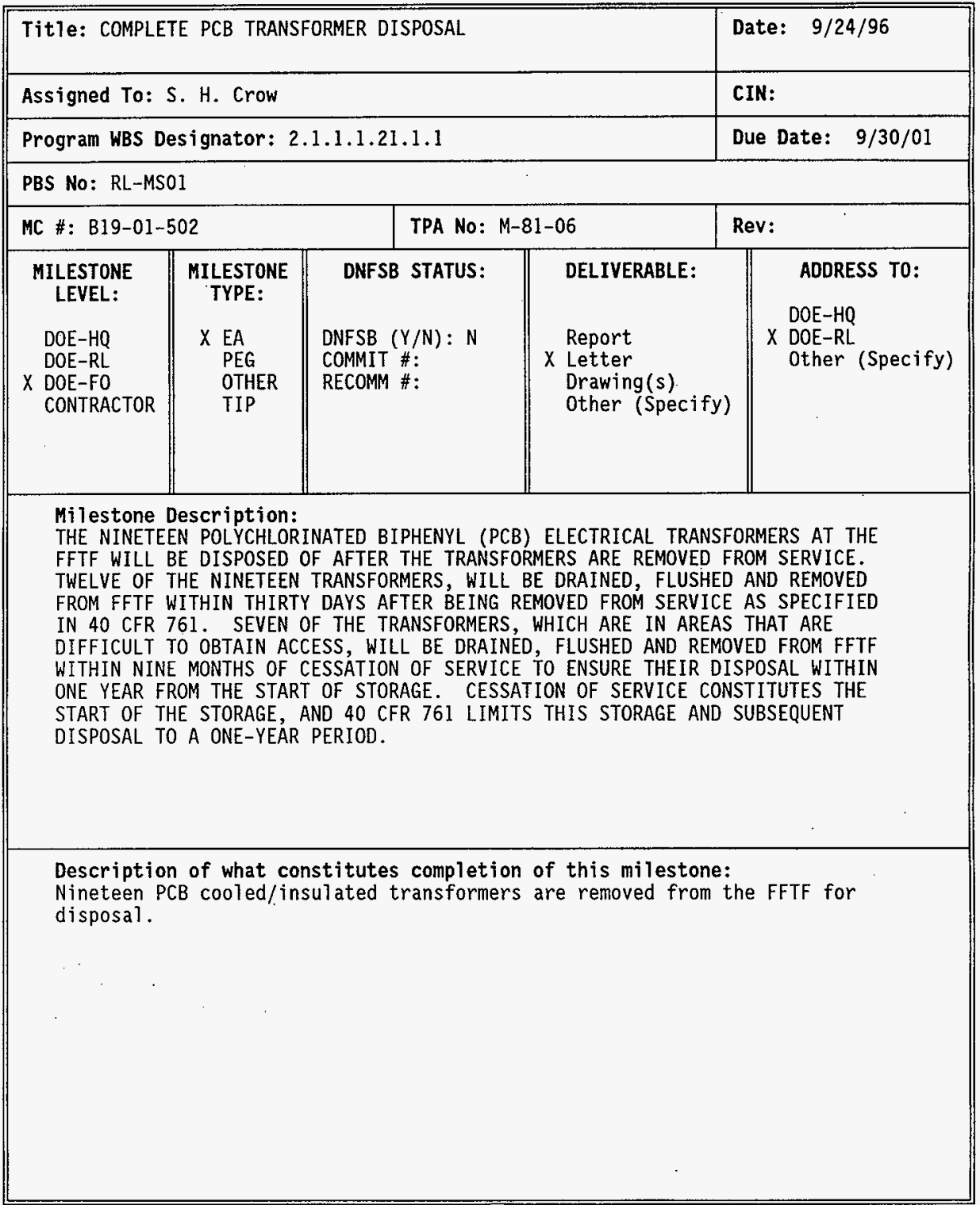




\section{PHMC}

\section{MILESTONE DESCRIPTION SHEET}

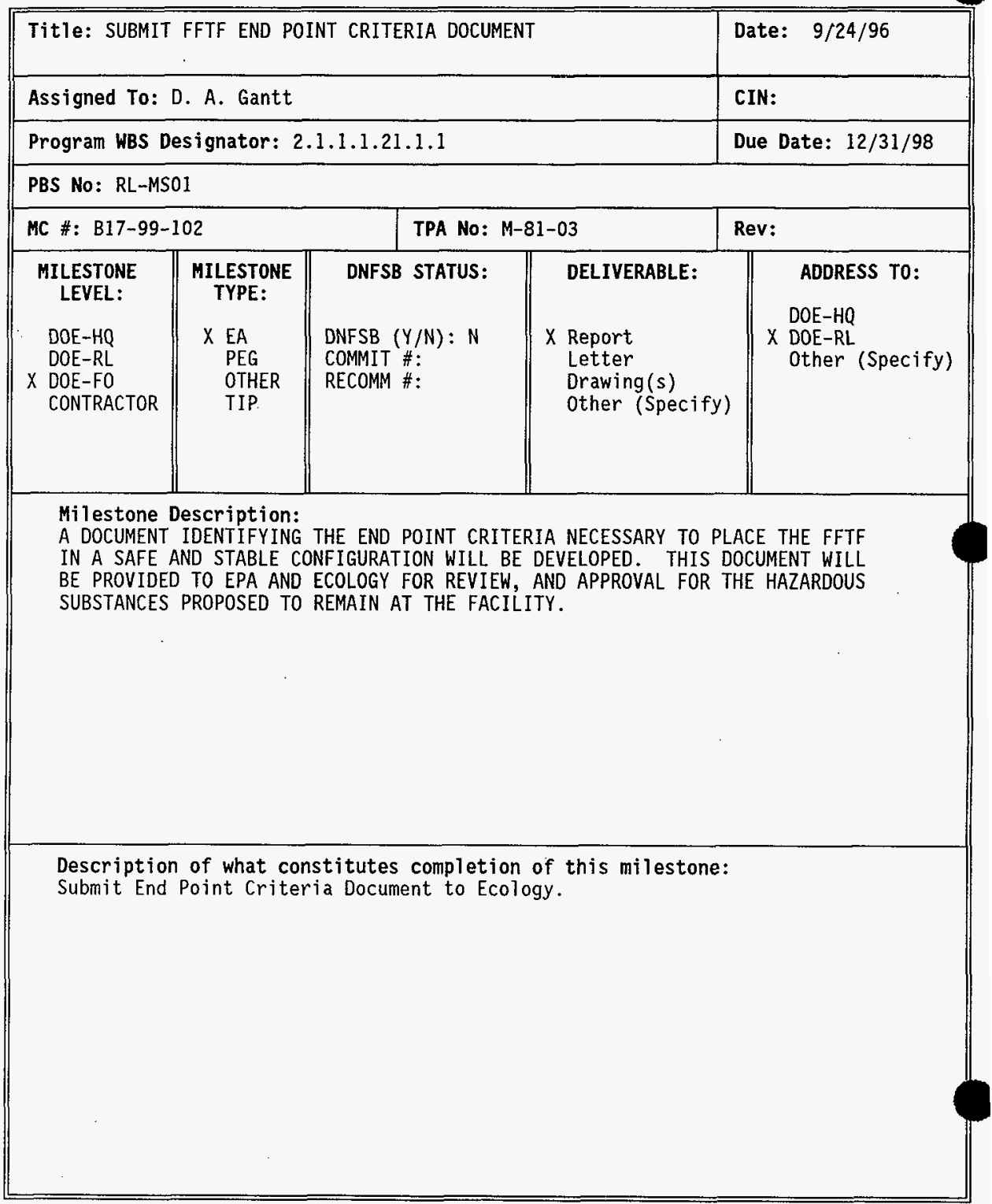




\section{PHMC}

MILESTONE DESCRIPTION SHEET

\begin{tabular}{|c|c|c|c|c|}
\hline \multicolumn{4}{|c|}{$\begin{array}{c}\text { Title: COMPLETE FFTF TRANSITION AND INITIATE THE } \\
\text { S\&M PHASE }\end{array}$} & Date: $9 / 24 / 96$ \\
\hline \multicolumn{4}{|c|}{ Assigned To: R. K. Hulvey } & CIN: \\
\hline \multicolumn{4}{|c|}{ Program WBS Designator: 2.1.1.1.21.1.1 } & Due Date: $12 / 31 / 01$ \\
\hline \multicolumn{5}{|c|}{ PBS No: RL-MSO1 } \\
\hline \multicolumn{2}{|c|}{ MC \#: B17-02-101 } & \multicolumn{2}{|c|}{ TPA No: M-81-00 } & Rev: \\
\hline $\begin{array}{l}\text { MILESTONE } \\
\text { LEVEL: } \\
\text { DOE-HQ } \\
\text { DOE-RL } \\
\text { X DOE-FO } \\
\text { CONTRACTOR }\end{array}$ & $\begin{array}{l}\text { MILESTONE } \\
\text { TYPE: } \\
\text { X EA } \\
\text { PEG } \\
\text { OTHER } \\
\text { TIP }\end{array}$ & $\begin{array}{l}\text { DNFSB STATUS: } \\
\text { DNFSB }(Y / N): N \\
\text { COMMIT \#: } \\
\text { RECOMM \#: }\end{array}$ & $\begin{array}{l}\text { DELIVERABLE: } \\
\\
\text { Report } \\
\text { X Letter } \\
\text { Drawing(s) } \\
\text { Other (Specify) }\end{array}$ & $\begin{array}{l}\text { ADDRESS TO: } \\
\text { DOE-HQ } \\
\times \text { DOE-RL } \\
\text { Other (Specify) }\end{array}$ \\
\hline \multicolumn{5}{|c|}{$\begin{array}{l}\text { Milestone Description: } \\
\text { This major milestone will be achieved by completion of all activities } \\
\text { necessary to achieve the end point criteria for placing the facility in a } \\
\text { safe and stable surveillance and maintenance mode. }\end{array}$} \\
\hline \multicolumn{5}{|c|}{$\begin{array}{l}\text { Description of what constitutes completion of this milestone: } \\
\text { The End Point Criteria Checklist has been completed and the Surveillance } \\
\text { and Maintenance Plan has been implemented. }\end{array}$} \\
\hline
\end{tabular}


FAST FLUX TEST FACILITY

LIFE CYCLE COST BASELINE (BCWS) BY YEAR BY FUND TYPE

BY PROJECT BASELINE SUMMARY (PBS)

FY 1999

\begin{tabular}{|c|c|c|c|c|c|c|c|c|c|c|c|}
\hline $\begin{array}{r}\text { PROJECT WBS: } \\
\text { PBS NO: }\end{array}$ & $\begin{array}{r}2.0 .1 \\
\text { RL-MS01 }\end{array}$ & & & & 00 s) & & & & & & \\
\hline PBS TITLE: & FFTF & & & & & & & & & & SUETOT \\
\hline FUND TYPE & FY1997 & FY1998 & FY 1999. & FY2000 & FY2001 & FY2002 & FY2003 & FY2004 & $\mathrm{FY} 2005$ & FY2006 & FY2006 \\
\hline OPERATING EXPENSE & 31,100 & - & 44,005 & - & - & - & - & - & $\overline{-}$ & ? & 72,105 \\
\hline & & & 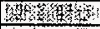 & & & & & & & & \\
\hline CENRTC & - & - & mos & - & - & - & - & - & - & - & 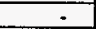 \\
\hline & & & W & & & & & & & & \\
\hline GENERAL PLANT PROJECT & - & - & 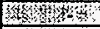 & - & - & - & . & - & - & $\div$ & 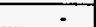 \\
\hline & & & 得6 & & & & & & & & \\
\hline LINE ITEM (List Each One) & & & WH' & & & & & & & & \\
\hline 0 & 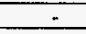 & - & 10 & - & - & - & - & - & - & - & - \\
\hline & $=$ & - & W & $=$ & - & - & - & - & - & - & 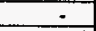 \\
\hline & - & - & Wy & $=$ & - & $=$ & - & 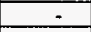 & - & - & - \\
\hline - & - & - & WXOH & $=$ & $=$ & - & - & - & - & - & - \\
\hline 0 & - & - & 3. & - & - & - & $=$ & $=$ & - & - & - \\
\hline & $=$ & - & 36 & - & - & $\overline{-}$ & $\dot{\square}$ & - & - & $\div$ & - \\
\hline Subtotal Line Items & - & - & How & . & - & - & - & $=$ & - & - & - \\
\hline Escalation & - & - & Whot & & - & - & - & - & - & - & 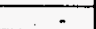 \\
\hline TOIALBCWSARB & 3100: & 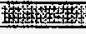 & 940005 & 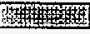 & 9 & 3. & W & 政 & 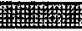 & 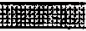 & 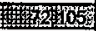 \\
\hline & & & and & & & & & & & & \\
\hline MGMT RESERVEF & - & - & \%ring & - & - & - & - & $=$ & - & - & - \\
\hline & & & W & & & & & & & & \\
\hline LINE ITEM CONTIHGENCY ${ }^{2}$ & - & - & Esmons & $=$ & $\overline{-}$ & - & $\dot{-}$ & - & - & - & - \\
\hline & & & 30 & & & & & & & & \\
\hline TRANSFERS $^{3}$ & - & $=$ & 162 & $\div$ & - & - & - & - & - & - & 162 \\
\hline & & & Hikn & & & & & & & & \\
\hline Subtotal & $z$ & - & 16, 162 & - & $=$ & 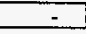 & $\dot{-}$ & - & - & - & 162 \\
\hline Escalation & - & 5 & Wor & & $\div$ & 8 & - & - & - & - & - \\
\hline 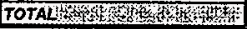 & 31,100 & ming & 414167 & Whon & 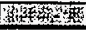 & 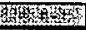 & 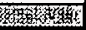 & 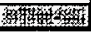 & 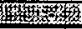 & 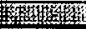 & 70 \\
\hline
\end{tabular}

'Budgeted Cost of Work Scheduled (BCWS) Equals Performance Measurement Baseline (PMB); Expense Carryover is Not tncluded 'Management Reserve and Line ltem Contingency Held by RL.

'Funds/Workscope Transferred to Other Sites, Transferred to Hanford from Other Sites, and/or Funds/Workscope Controlled by RL. 
FAST FLUX TEST FACILITY

LIFE CYCLE COST BASELINE (BCWS) BY YEAR BY FUND TYPE

BY PROJECT BASELINE SUMMARY (PBS)

FY 1999

\begin{tabular}{|c|c|c|c|c|c|c|c|c|c|c|c|c|c|}
\hline $\begin{array}{r}\text { PROJECT WBS: } \\
\text { PBS NO: }\end{array}$ & $\begin{array}{r}2.0 .1 \\
\text { RL-MS01 } \\
\end{array}$ & & & & & 000 s) & & & & & & & \\
\hline PBS TITLE: & FFTF & & & & & & & & & & & & TOTAL \\
\hline FUND TYPE & FY2007 & FY2008 & FY2009 & FY2010 & $\begin{array}{l}\text { FY2011: } \\
\text { FY2015 }\end{array}$ & $\begin{array}{l}\text { FY2016- } \\
\text { FY2020 }\end{array}$ & $\begin{array}{l}\text { FY2021: } \\
\text { FY2025 }\end{array}$ & $\begin{array}{l}\text { FY2026. } \\
\text { FY2030 }\end{array}$ & \begin{tabular}{|l|} 
FY2031- \\
FY2036
\end{tabular} & \begin{tabular}{|l|} 
FY2036 \\
FY2040
\end{tabular} & \begin{tabular}{|l|} 
FY2041- \\
FY2045
\end{tabular} & $\begin{array}{l}\text { FY2046 } \\
\text { FY2050 }\end{array}$ & $\begin{array}{l}\text { FY1997- } \\
\text { FY2050 }\end{array}$ \\
\hline OPERATING EXPENSE & - & - & - & - & - & $\div$ & - & $\Xi$ & - & - & $\because$ & - & 72,105 \\
\hline & & & & & & & & & & & & & \\
\hline CENRTC & - & - & $=$ & - & $=$ & - & - & - & - & $=$ & - & $\cdot$ & - \\
\hline & & & & & & & & & & & & & \\
\hline GENERAL PLANT PROJECT & - & - & - & - & - & - & - & - & $=$ & $\therefore$ & - & - & - \\
\hline LINE ITEM Ust Each One) & & $m$ & & & & & & & - & & - & & \\
\hline & - & - & - & - & $=$ & - & - & - & - & - & - & - & \\
\hline & - & - & - & 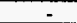 & . & - & - & - & . & - & - & . & 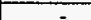 \\
\hline & - & - & - & . & - & . & - & - & - & - & - & - & - \\
\hline & - & - & - & . & - & - & .. & - & - & - & - & - & - \\
\hline 0 & - & - & - & - & - & - & - & - & - & - & . & - & - \\
\hline & . & - & - & - & - & - & - & - & - & - & - & - & - \\
\hline Subtotal Lne Items & - & - & - & - & - & - & - & $=$ & - & - & . & ? & - \\
\hline Escalation & $\cdot$ & $\therefore$ & & & & - & $\ldots$ & & 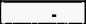 & - & - & $=$ & \\
\hline FOTALBCWSPMB & astis & 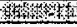 & Fin & 5 (1) & 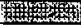 & 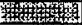 & 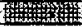 & (1) & 酐) & 15 & 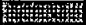 & & 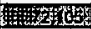 \\
\hline & & & & & & & & & & & & & \\
\hline MGMT RESERVE ${ }^{T}$ & - & - & - & $=$ & - & 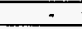 & $\dot{\square}$ & 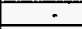 & $\cdot$ & $\dot{-}$ & $\div$ & $\dot{\square}$ & - \\
\hline LIME ITEM CONTIMGENCY ${ }^{2}$ & $\because$ & $\because$ & - & - & - & 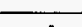 & 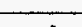 & - & -5 & 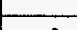 & 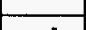 & s & \\
\hline & & & & & & & & & & & & & \\
\hline TRANSFERS $^{3}$ & - & - & - & - & - & - & - & - & - & - & - & $\because$ & 162 \\
\hline & & & & & & & & & & & & & \\
\hline Subtotal & - & - & - & - & - & $=$ & - & - &. & - & $\cdot$ & - & 162 \\
\hline Escalation & & $=$ & $\overline{-}$ & - & $\cdot$ & - & - & & . & $z_{2}$ & - & - & \\
\hline TOTALWES & B. & 6 & 83 & 8 & $\overline{4}$ & 8 & 然 & 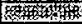 & (2) & tret & 濯 & & $67 \mathrm{k}$ \\
\hline
\end{tabular}

'Budgeted Cost of Work Scheduled (BCWS) Equals Performance Measurement Baseline (PMB); Expense Carryover is Not Included

'Management Reserve and Line ltem Contingency Held by RL

${ }^{3}$ FundsWWorkscope Transferred to Other Sites, Transferred to Hanford from Other Sites, and/or Funds/Workscope Controlled by RL. 


\section{BUDGET AUTHORITY (BIA) BY YEAR BY FUND TYPE} BY PROJECT BASELINE SUMMARY (PBS)

FY 1999

(\$000s)

\begin{tabular}{|c|c|c|}
\hline PROJECT WBS: & 2.0 .1 & \\
\hline PBS NO: & RL-MS01 & \\
\hline PBS TITLE: & FFTF & \\
\hline & $\begin{array}{c}\text { TARGET } \\
\text { B/A }\end{array}$ & 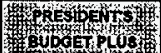 \\
\hline FUND TYPE & FY1998 & 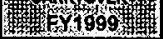 \\
\hline OPERATING EXPENSE & - & 41200 \\
\hline & & (7) \\
\hline CENRTC & - & 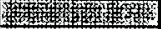 \\
\hline & & 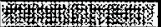 \\
\hline GENERAL. PLANT PROJECT & - & Hin \\
\hline & & 4 (1) \\
\hline LINE ITEM R/st Each One) & & ST) \\
\hline a & - & 吻 \\
\hline 0 & - & 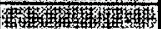 \\
\hline 0 & - & 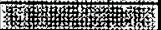 \\
\hline 0 & - & 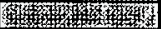 \\
\hline 0 & - & 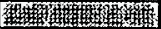 \\
\hline$\overline{0}$ & - & 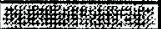 \\
\hline Subtotal Line ftems & - & r对 \\
\hline & & 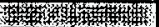 \\
\hline 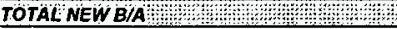 & 15: & \% \\
\hline & & 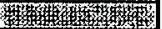 \\
\hline ESTIMATED FY 1998 CARRYOVER & & Y) \\
\hline & & 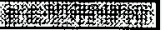 \\
\hline TOTAL NEW B/A+CARRYOVER & + & $40 \quad 41,200$ \\
\hline
\end{tabular}

'Estimated Carryover Is NOT Included In Cost Baseline; Change Request For Actual Carryover Submitted After September 30, 1998. 
HNF-SP-1240

Rev. 1

\section{Supplemental Information}

$-\cdots$ 


\section{FY $1999-2000$ Project Priority Lists}

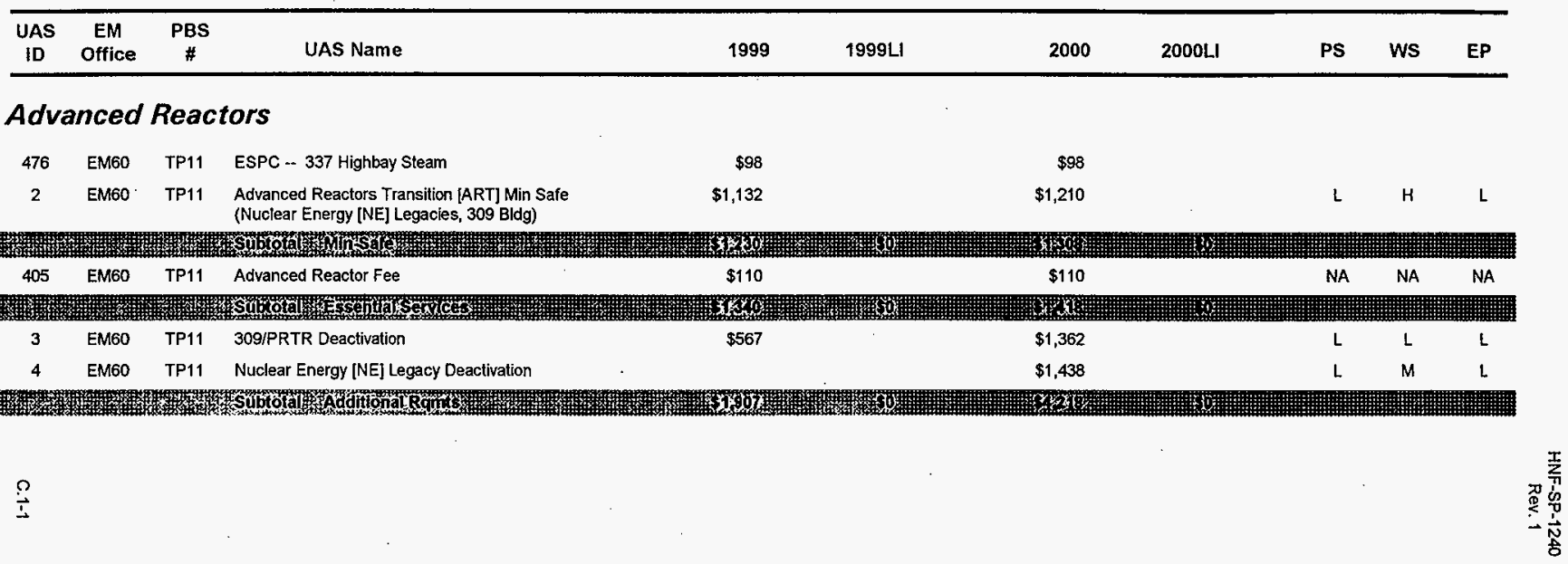


ITEM 1

PartI

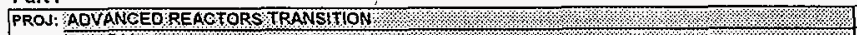

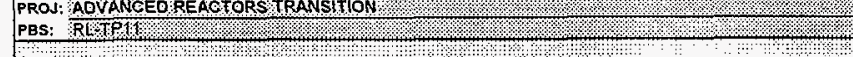

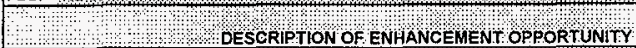

\begin{tabular}{|c|c|c|c|}
\hline \multicolumn{2}{|c|}{ Ranges } & & \\
\hline $\mathrm{ROM}$ & ROMESTMATED & FUNDING RREOURED & WOSHSYWHERE \\
\hline $\begin{array}{l}\text { PROBABILITY } \\
\text { OF SUCCESS(\%) }\end{array}$ & $\begin{array}{c}\text { LIFE CYCLE } \\
\text { SAVINGS (SMillions) }\end{array}$ & $\begin{array}{l}\text { TO INVESTIGATE } \\
\text { OPPORTUNITY (SThous) }\end{array}$ & FUNDING IS REQUIRED \\
\hline 100 & 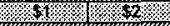 & & \\
\hline & & 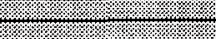 & s! \\
\hline 8 & $\$ 2$ & sin & ming \\
\hline
\end{tabular}

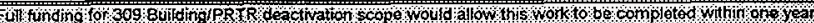

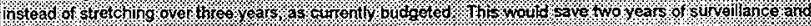

maitenanco costs

Total

\section{Part II \\ STEPS/SCHEOULE TO ACCONPLISH PART I ENHANCEMENTS}

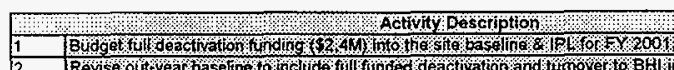

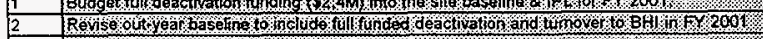

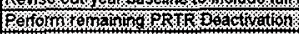

.

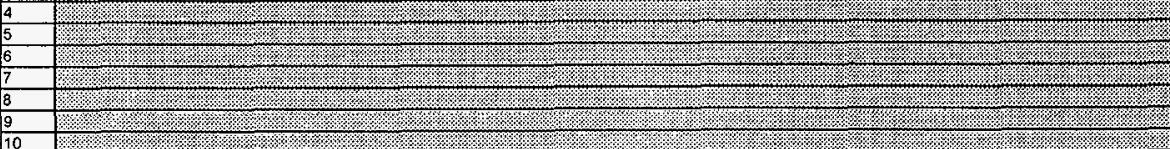

\begin{tabular}{|c|c|c|c|}
\hline \multicolumn{2}{|c|}{ Dates } & \multicolumn{2}{|c|}{ BCRRE Eulled } \\
\hline stat & Compléto & 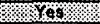 & No \\
\hline 107698 & $6 \longdiv { 3 0 \% 9 }$ & & \\
\hline 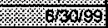 & $\times 63130$ & 签器 & \\
\hline $10 x=0$ & 3.953001 & & \\
\hline $28 \%$ & 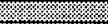 & 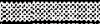 & 9 \\
\hline & \% & & \\
\hline 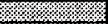 & 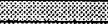 & (2) & 簽 \\
\hline 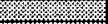 & & & \\
\hline 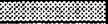 & (1) & 暗 & 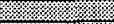 \\
\hline V. & 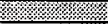 & 筮 & \% \\
\hline W6/ & 6\% & 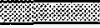 & W \\
\hline
\end{tabular}

$\S$

\section{ITEM 2}

Part I

PROJ: ADVANCED REACTORS TRANSITION

PBS:

14. DESCRIPTHONOOF ENHANCEMENT ORPORTUNTTY

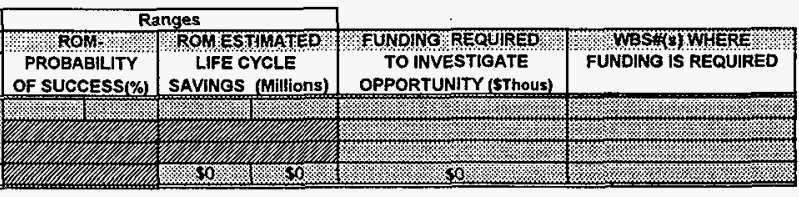

\section{Part II}

STEPS/SCHEDULE TO ACCOMPLISH PART I ENHANCEMENTS

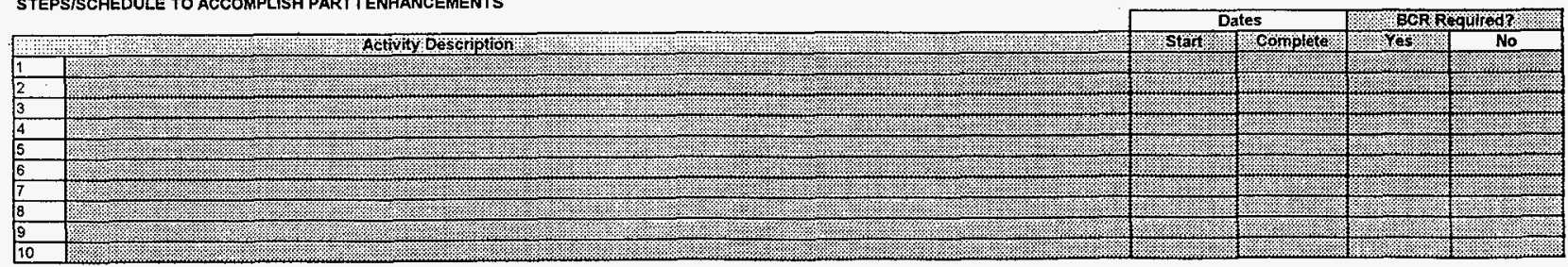




\section{PERFORMANCE ENHANCEMENT WORKSHEET}

ITEM 3

Part 1

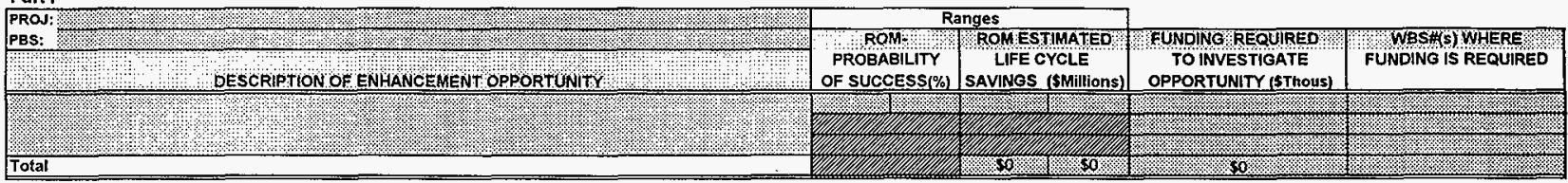

Part II

STEPS/SCHEDULE TO ACCOMPLISH PART I ENHANCEMENTS

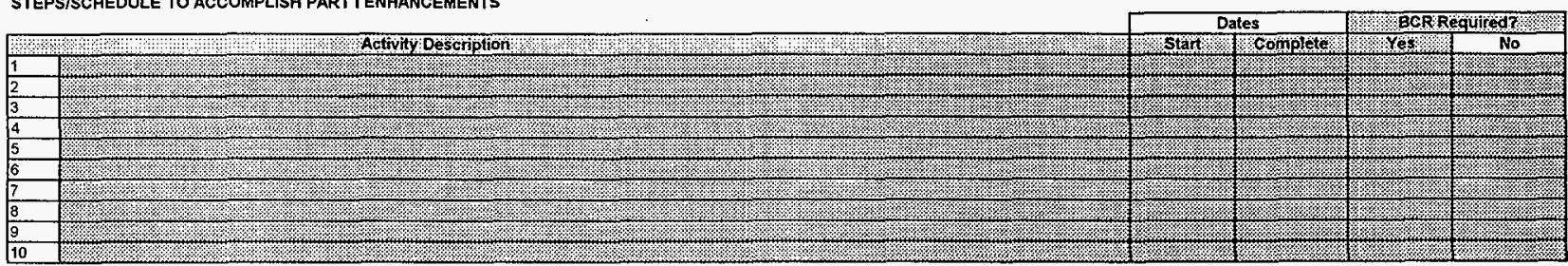

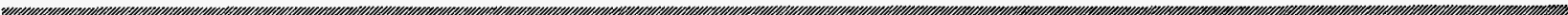

\section{ITEM 4}

Part!

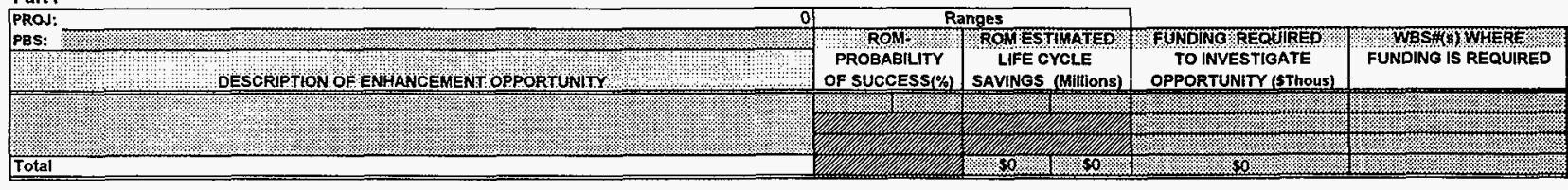

\section{Part II}

STEPS/SCHEDULE TO ACCOMPLISH PART I ENHANCEMENTS
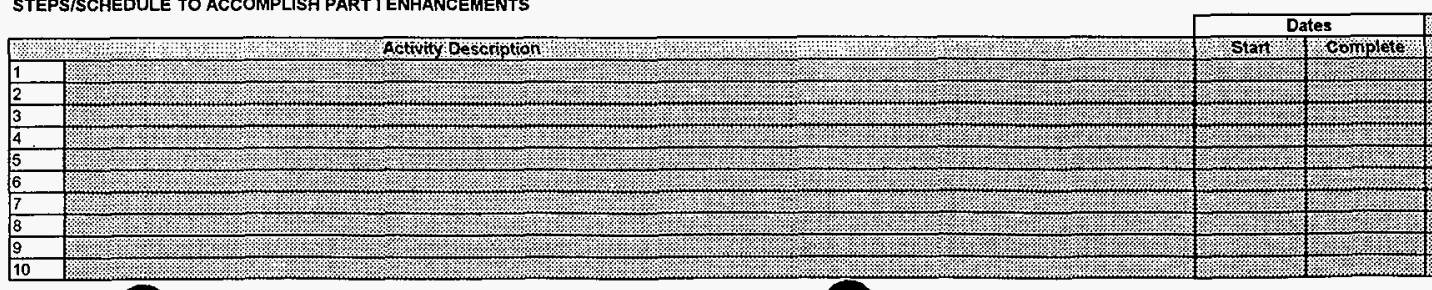


\section{Performance Objectives and Measures}

\section{Advanced Reactors Transition Mission}

\begin{tabular}{|c|c|c|c|c|c|c|c|c|c|}
\hline $\begin{array}{l}\text { HSP Success IndicatorI } \\
\text { Critical Success Factor }\end{array}$ & Strategic Outcome/Goal & Performance Objective & Output/Metric & $\begin{array}{l}\text { EM Management } \\
\text { Commitment }\end{array}$ & FY 1999 & FY 2000 & FY 2001 & FY $97-06$ & $\begin{array}{l}\text { End Point } \\
\text { Target }\end{array}$ \\
\hline \multirow[t]{7}{*}{$\begin{array}{l}\text { TP11 } \\
\text { Reduced risk; reduced } \\
\text { inventory; reduced } \\
\text { mortgages; increased land } \\
\text { available }\end{array}$} & Facilities Transition goal & $\begin{array}{l}\text { Maintain the FFTF in a safe } \\
\text { and compliant standby } \\
\text { condition. The condition of } \\
\text { the plant hardware, software } \\
\text { and personnel will be } \\
\text { preserved in a manner not to } \\
\text { preclude a plant restart. }\end{array}$ & $\begin{array}{l}\text { SNF fuel stabilized during the } \\
\text { period } \mathrm{m} 3\end{array}$ & No & & & & 2.4 & 2.4 \\
\hline & & & $\begin{array}{l}\text { SNF fuel stabilized during the } \\
\text { period MTHM }\end{array}$ & No & & & & 1.81 & 1.81 \\
\hline & & $\begin{array}{l}\text { Transition } 300 \text { Area } \\
\text { contaminated facilities to low } \\
\text { risk, low cost surveillance \& } \\
\text { maintenance state }\end{array}$ & $\begin{array}{l}\text { Clean out the balance of the } \\
\text { PRTR containment }\end{array}$ & $\begin{array}{l}\text { No } \\
\text { 9/28/01 }\end{array}$ & & & & & \\
\hline & & & $\begin{array}{l}\text { Clean sodium residuals from } \\
\text { two drained storage tanks } \\
\text { previously removed from } 221-T\end{array}$ & $\begin{array}{l}\text { No } \\
9 / 28 / 01\end{array}$ & - & & & . & \\
\hline & & & $\begin{array}{l}\text { Facilities, final completion of } \\
\text { decommissioning }\end{array}$ & No & & & & 2 & 2 \\
\hline & & & $\begin{array}{l}\text { Facilities/buildings deactivated } \\
\text { during the period }\end{array}$ & Yes & & & & 3 & 3 \\
\hline & & . & $\begin{array}{l}\text { Facilities/buildings deactivated } \\
\text { during the period/Complete } \\
\text { disposition of Hanford Site } \\
\text { non-radioactive sodium }\end{array}$ & $\begin{array}{l}\text { No } \\
7 / 30 / 04\end{array}$ & & & & 3 & 3 \\
\hline
\end{tabular}




\section{Performance Objectives and Measures}

Advanced Reactors Transition Mission

\begin{tabular}{|c|c|c|c|c|c|c|c|c|c|}
\hline $\begin{array}{l}\text { HSP Success Indicator/ } \\
\text { Critical Success Factor }\end{array}$ & Strategic Outcome/Goal & Performance Objective & Output/Metric & $\begin{array}{l}\text { EM Management } \\
\text { Commitment }\end{array}$ & FY 1999 & FY 2000 & FY 2001 & FY $97-06$ & $\begin{array}{l}\text { End Point } \\
\text { Target }\end{array}$ \\
\hline \multirow[t]{4}{*}{$\begin{array}{l}\text { TP11 } \\
\text { Reduced risk; reduced } \\
\text { inventory; reduced } \\
\text { mortgages; increased land } \\
\text { available }\end{array}$} & FacilitiesTransition goal & $\begin{array}{l}\text { Transition } 300 \text { Area } \\
\text { contaminated facilities to low } \\
\text { risk, low cost surveillance \& } \\
\text { maintenance state }\end{array}$ & $\begin{array}{l}\text { Facilities/buildings not yet } \\
\text { deactivated }\end{array}$ & No & & 4 & 4 & & \\
\hline & . & & $\begin{array}{l}\text { Faclities/buildings deactivated } \\
\text { during the period/Deactive } \\
309 \text { Building }\end{array}$ & $\begin{array}{l}\text { Yes } \\
9 / 30 / 03\end{array}$ & & & & 1) & 1 \\
\hline & & & $\begin{array}{l}\text { Hazardous waste cisposal, on- } \\
\text { site commercial m3 }\end{array}$ & No & & 2 & & 2 & 2 \\
\hline & & & $\begin{array}{l}\text { Remove insulation from } 309 \\
\text { Building dome }\end{array}$ & $\begin{array}{l}\text { No } \\
9 / 30 / 99\end{array}$ & & & & & \\
\hline
\end{tabular}




\section{Performance Objectives and Measures}

\section{Fast Flux Test Facility Mission}

\begin{tabular}{|c|c|c|c|c|c|c|c|c|c|}
\hline $\begin{array}{l}\text { HSP Success Indicatorf } \\
\text { Critical Success Factor }\end{array}$ & Strategic Outcome/Goal & Performance Objective & Output/Metric & $\begin{array}{l}\text { EM Management } \\
\text { Commitment }\end{array}$ & FY 1999 & FY 2000 & FY 2001 & FY 97-06 & $\begin{array}{c}\text { End Point } \\
\text { Target }\end{array}$ \\
\hline $\begin{array}{l}\text { MS01 } \\
\text { Reduced risk; reduced } \\
\text { inventory; reduced } \\
\text { mortgages; increased land } \\
\text { available }\end{array}$ & Facilities Transition goal & $\begin{array}{l}\text { Maintain the FFTF in a safe } \\
\text { and compliant standby } \\
\text { condition. The condition of } \\
\text { the plant hardware, software } \\
\text { and personnel will be } \\
\text { preserved in a manner not to } \\
\text { preclude a plant restat. }\end{array}$ & $\begin{array}{l}\text { Complete maintenance } \\
\text { activities associated with } \\
\text { "maintaining health of the } \\
\text { facility." Specific activities will } \\
\text { be defined at the start of each } \\
\text { of the three consecutive four- } \\
\text { month periods. }\end{array}$ & $\begin{array}{l}\text { No } \\
9 / 30 / 99\end{array}$ & & & & & \\
\hline
\end{tabular}




\subsection{PBS RL-TP11, ADVANCED REACTORS TRANSITION}

\section{Changes from the FY 1998 MYWP (as revised by BCRs):}

Deactivation activities for 309 Building and for NE Legacies sodium test loops are suspended for FY $\mathbf{2 0 0 0}$ due to priorities being below the funded level in the IPL.

Activities are assumed to be funded again in FY 2001. This results in an additional oneyear delay in project completion.

\subsection{Outcomes Based on Proposed Updates}

- EM Management Commitments:

There are no existing EM Management Commitments associated with this PBS.

- PBS Performance Metrics

Deactivation dates for the 309 Building and the NE Legacy sodium test loops will slip by an additional year.

309 Building is: Oct01 Proposed: Oct02 (1 facility)

NE Legacies is: Jul03 Proposed: Jul04 (3 facilities)

- FY 1999 Interim End Points

$\$ 0.5 \mathrm{M}$ will be available for deactivation work (D\&C) at the $309 \mathrm{Bidg}$. The proposed priority is to remove the asbestos containing insulation from the outside of the dome during this fiscal year. Based on preliminary cost estimates, there will be little funding available for contingency.

\subsection{Technical Changes - Based on Proposed Updates}

- Technical Requirements

There are NO CHANGES to the technical requirements.

- Technical Workscope

There are NO CHANGES to the technical workscope.

\subsection{Schedule Changes - Based on Proposed Updates}

- Regulatory, DNFSB, and/or HQ Milestones

TPA Target milestone M-92-11-T01, due March 2002 will be completed no sooner than July 2004. As a "Target" milestone, there is no enforcement action associated with this delay.

- Affected Project Interfaces

RL-TP14, 300 Area Revitalization, will not receive the 337 Highbay, 335, and $3718 \mathrm{M}$ Buildings until October 2004. (Was scheduled October 2003.)

RL-ER05, Surveillance and Maintenance, will not receive the 309 Building until October 2002. (Was scheduled October 2001.)

- Potential Slippages of Scheduled Activities as a Result of the BUG

Schedule changes are due to the low priority for requested D\&C funding in FY 2000. The minimal D\&C funding for FY 1999, as provided for in the BUG, was previously identified in the FY 1998 MYWP. 


\subsection{Cost - Based on Proposed Updates}

- Costs as a Result of ltems 2 through 4

The lack of D\&C funding in FY 2000 will result in an added, total project cost of approximately $\$ 1.4 \mathrm{M}$, primarily for an additional year of surveillance and maintenance.

\subsection{Funding}

- As a result of updates to expected available funds, what strategy/path fonward do you recommend for any updates to the current life-cycle baseline?

FY 1999 funding and BCWS are consistent with that projected in the FY 1998 MYWP.

FY 2000 funding is anticipated to be limited to S\&M and essential services, $\$ 1,418 \mathrm{~K}$, vs. the $\$ 4,152 \mathrm{~K}$ budgeted in the FY 1998 MYWP.

Path forward:

- Reassess site priorities to determine how many years these facilities may be held in the current status, prior to completing deactivation.

- Attempt to gain increased D\&C funding for the 309 Building in the FY 2001 budget process.

- Although relatively low cost projects, the low risks and low mortgage reduction $(<\$ 750 \mathrm{k} / \mathrm{yr})$ associated with these projects mitigate against near-term funding to completion.

\subsection{Key Areas of Focused Emphasis}

- Performance Obiectives and Performance Metrics

See listing in section C.3.1 of this MYWP.

- Performance Enhancements

It is probable that the 309 Building deactivation could be completed in a single year, saving lifecycle S\&M costs. Further assessment of this possibility will be pursued.

- Technical Issues Management List (TIML) Issues

There are no TIML Issues associated with this PBS.

- Technology insertion Points

There are no identified technology issues related to these activities. 
Changes from the FY 1998 MYNP (as revised by BCRs):

The FFTF will remain in Standby throughout FY 1999, rather than beginning an EIS, as was assumed in the FY 1998 MYWP. Pseudo-PBS number RL-MS01 is assigned to allow tracking of this NE funded work within the site integration systems.

\subsection{Outcomes Based on Proposed Updates}

- EM Management Commitments:

Not applicable; this project is funded from DOE-NE

- PBS Performance Metrics

Not Applicable.

- FY 1999 Interim End Points

Complete work scope associated with "maintaining the health of the facility." An initial list of specific work to be accomplished in this area will be defined for each four month period and approved by RL-SPO.

Complete repairs/upgrades to the Solid Waste Cask (SWC) hoist through the completion of fabrication and complete the grapple system design.

Complete field installation of control system upgrades for the Closed Loop Ex-Vessel Machine.

Complete design of control system upgrades for the Sodium Removal System.

\subsection{Technical Changes - Based on Proposed Updates}

- Technical Requirements

There are NO CHANGES to the technical requirements.

- Technical Workscope

The SWC repair is new detail in the effort to preserve equipment operable for a potential restart, and, as necessary, for resumption of transition to shutdown.

\subsection{Schedule Changes - Based on Proposed Updates}

- Regulatory, DNFSB, and/or HQ Milestones

Deferral of the M-81 series of milestones is still pending final approval of TPA

Change M-81-97-01A.

- Affected Project Interfaces

None. FFTF Standby was initiated in FY 1997.

- Potential Slippages of Scheduled Activities as a Result of the BUG

As described above. The BUG, section C.10 directs that the "FFTF is to remain in 'standby'..." 


\subsection{Cost - Based on Proposed Updates}

- Costs as a Result of Items 2 through 4

FY 1999 costs will be $\$ 41.0 \mathrm{M}$. Lifecycle costs are indeterminate due to the lack of a clear mission direction.

\subsection{Funding}

- As a result of updates to expected available funds, what strategy/path forward do you recommend for any updates to the current life-cycle baseline?

Life-cycle baseline cannot be determined until a mission decision has been made by DOE-HQ.

\subsection{Key Areas of Focused Emphasis}

- Performance Objectives and Performance Metrics

Maintain the FFTF in a safe and compliant standby condition. The condition of the plant hardware, software, and personnel shall be maintained in a manner not to preclude a plant restart.

- Performance Enhancements

None identified.

- Technical issues Management List (TIML) Issues

TWRS milestone M-50-03 confirmed advanced pretreatment will not be required. If FFTF is shutdown, the baseline will be developed considering the use of FFTF sodium to produce sodium hydroxide for tank waste pretreatment.

- Technology Insertion Points

There are no identified technology issues related to these activities. 
HNF-SP-1240

Rev. 1

DISTRIBUTION

Number of Copies

\section{ON SITE}

23 B\&W Hanford Company

G. J. Boehnke

D. B. Cartmell

S. V. Doebler

D. A. Gantt (5)

S. Guttenberg

R. K. Hulvey

L. M. Kinsey

G. E. Kulynych

E. F. Loika

D. M. Lucoff

I. L. Metcalf

J. M. Montano

L. A. Nelsen

J. E. Parker

S. W. Scott

W. V. Witherspoon

R. O. Zimmerman

TPO Files (2)
N1-41

R3-50

N2-34

N2-13

N2-53

N2-33

R3-61

H5-31

N2-51

N2-51

L6-26

N2-51

N2-50

N2-11

N2-57

N2-13

N2-57

N2-13

\section{Number of Copies}

\section{ON SITE}

$4 \quad$ Pacific Northwest National Laboratory

W. J. Apley

Hanford Technical Library

(N. Doran)

J.E. Sall

DOE-RL Reading Room (T. L. Traub)
N2-36

P8-55

K3-33

H2-53

4 Fluor Daniel Hanford, Inc.

D. B. Klos

N2-51

K. B. Tobler (3)

B3-53

3 Locklseed Martin Services, Inc.

Central Files (2) B1-03

Document Proc, Center A3-89

$10 \quad$ U.S. Department of Energy Richland Operations Office
R. A. Almquist
(3)
R3-79
D. H. Chapin
R3-79
T. H. Davies
R3-78
O. A. Farabee
R3-79
R. G. Hastings
R3-78
N. D. Moorer
(2)
A5-11
S. D. Stites
R3-79 